\title{
Effects of delayed fat supplementation on post-prandial rumen metabolism, lamb quality and fatty acid composition of rumen effluent
}

Quinn Stephan Baptiste

West Virginia University

Follow this and additional works at: https://researchrepository.wvu.edu/etd

\section{Recommended Citation}

Baptiste, Quinn Stephan, "Effects of delayed fat supplementation on post-prandial rumen metabolism, lamb quality and fatty acid composition of rumen effluent" (2009). Graduate Theses, Dissertations, and Problem Reports. 2850.

https://researchrepository.wvu.edu/etd/2850

This Dissertation is protected by copyright and/or related rights. It has been brought to you by the The Research Repository @ WVU with permission from the rights-holder(s). You are free to use this Dissertation in any way that is permitted by the copyright and related rights legislation that applies to your use. For other uses you must obtain permission from the rights-holder(s) directly, unless additional rights are indicated by a Creative Commons license in the record and/ or on the work itself. This Dissertation has been accepted for inclusion in WVU Graduate Theses, Dissertations, and Problem Reports collection by an authorized administrator of The Research Repository @ WVU.

For more information, please contact researchrepository@mail.wvu.edu. 
Effects of delayed fat supplementation on post-prandial rumen metabolism, lamb quality and fatty acid composition of rumen effluent

Quinn Stephan Baptiste, B.S, Ag; M.S. Reprod. Phys.

Dissertation submitted to the Davis College of Agriculture, Forestry, and Consumer Sciences

At West Virginia University

in partial fulfillment of the requirements

for the degree of

Doctor of Philosophy
in
Animal and Nutritional Sciences

Eugene Felton, Chair

P. Brett Kenney

Marie Krause

Joseph Moritz

${ }^{1}$ William B. Bryan

Division of Animal and Nutritional Sciences

${ }^{1}$ Division of Plant and Soil Sciences

Morgantown, West Virginia, 26505

2009

Keywords: animal nutrition, fat supplementation strategy, rumen metabolism, lamb fatty acid

Copyright 2009 Quinn S. Baptiste 


\begin{abstract}
Effects of delayed fat supplementation on post-prandial rumen metabolism, lamb quality and fatty acid composition of rumen effluent
\end{abstract}

Quinn S Baptiste

Sheep farmers have an option to incorporate fat supplements into the ration of grazing ruminants. Farmers choosing this option will have to select a time for offering that supplement. It might be practical to feed the supplement in the morning or evening. However, the time at which that supplement is fed should not compromise nutrient digestion or the enhancement of ruminant product fatty acid composition. Consequently, the effects of feeding a fat enriched supplement, at a delayed time on rumen metabolism, lamb quality, and fatty acid composition of effluent digesta were investigated in three experiments. In experiment 1, treatment (time of supplementation) of a soybean oil and soybean meal supplement on diurnal rumen activity and total tract nutrient digestion of lambs fed orchard grass hay were investigated. Treatment did not affect differences in hay intake, urine production, urine $\mathrm{NH}_{3}-\mathrm{N}$, nitrogen retention, or nutrient digestibility. However, time of supplementation did affect ruminal digestion and kinetics. In experiment 2, the afternoon feeding effects of fat, protein, and fat enriched protein supplements on performance and tissue fatty acid composition of grazed lambs were evaluated. The type of fat supplement that was fed to lambs influenced grazing activity, forage intake, lamb growth and fatty acid profile of tissues. Lastly, in experiment 3, the impact of delayed supplementation with fat, protein or a fat enriched protein blend, on diurnal changes in fermentative digestion, forage digestibility and effluent digesta fatty acid composition in continuous culture fermenters were investigated. In this study, delayed fat supplementation did not alter post-prandial fermentation or compromise fermentative digestion and nutrient digestibility. Producers who wish to utilize low levels of supplemental soybean oil to high forage fed lambs may not be overly concerned about the time at which that supplement is fed. 


\section{ACKNOWLEDGEMENTS}

I hereby formally thank my advisor Dr. Eugene Felton for providing the opportunity for me to pursue this degree program. His guidance and support was critical to my progress throughout the program. I will forever be thankful for his contributions toward my conceptualization of a philosophy of animal science research. The comments and assistance of my committee members, Drs. Brett Kenney, Joseph Moritz, Marie Krause, and William Bryan are also greatly appreciated. I would like to specially thank Dr. Domingo Mata Padrino for his numerous contributions towards the completion of this research. The assistance of the minority doctoral scholars program was immeasurable and thus I will forever be thankful to the Social Justice Department.

I wish to especially thank Drs. Marlon Knights and Doolarie Knights for their immense support over the years. The support of my dear parents, Alston and Joyce Baptiste, my sisters, Lydia, Marva, Gail, my brothers Desmond, Curtis, Clive, Shawn, Junior, and Nolan, my dearest wife, Sherri Baptiste and my daughters Raquel and Crystal is also greatly acknowledged.

Graduate students; Jason Gulas, Matthew Packard, Steve Chavez, Kevin Shaffer, Jason Smith, research assistants; Eric Nestor, Stephanie Paulie, Tammy Webster and the farm crew, also contributed to the completion of this project. I thank them all for their various contributions. 


\section{TABLE OF CONTENTS}

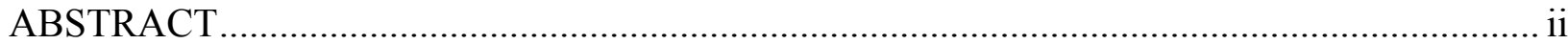

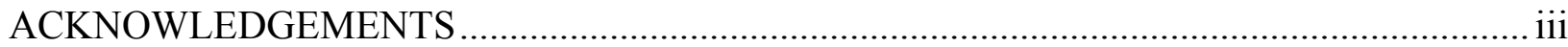

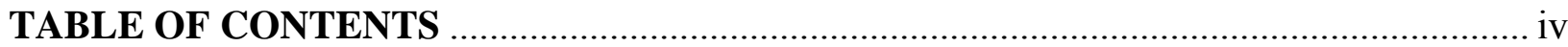

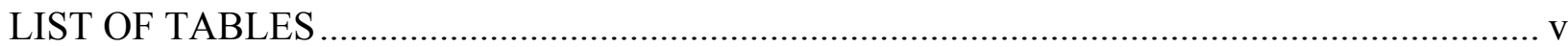

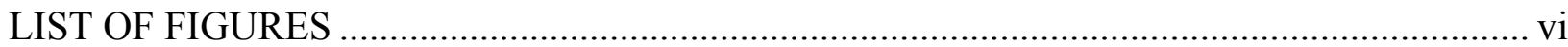

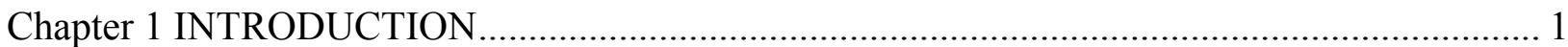

Chapter 2 : LITERATURE REVIEW .......................................................................... 4

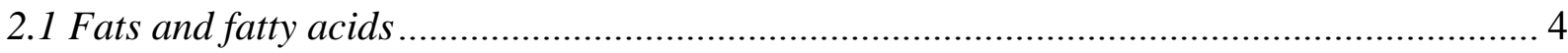

2.3 Management strategies for feeding fat ................................................................... 7

2.4 Diurnal variation in ruminal microbial population; implications on fat supplementation

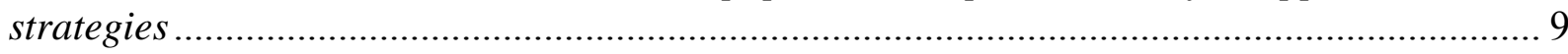

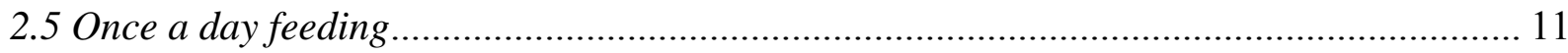

2.6 Effects of delayed feeding of fat supplement.................................................................. 17

2.61 Delayed feeding of rumen inert fat supplements.......................................................... 17

2.62 Delayed feeding of rumen active fats........................................................................ 20

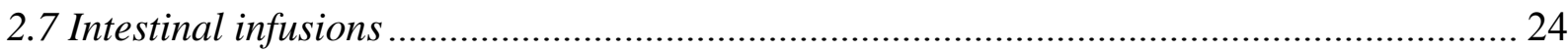

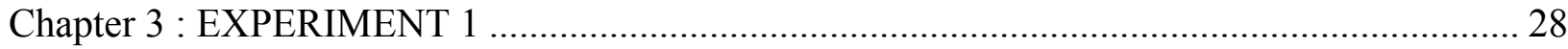

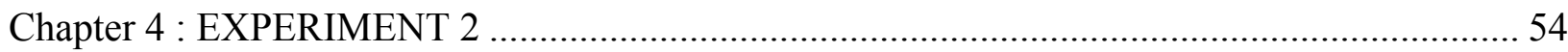

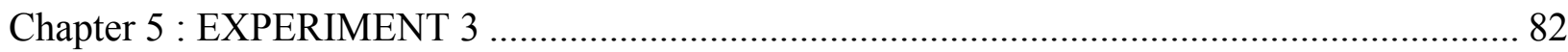

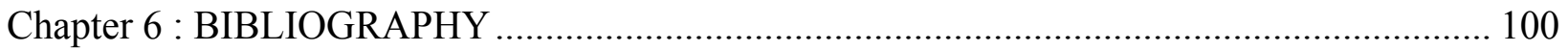

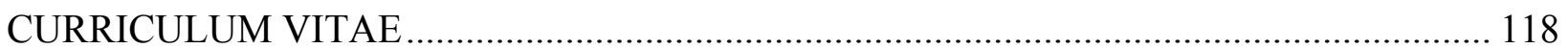




\section{LIST OF TABLES}

Experiment 1.

Table 1. Nutrient composition of orchard grass hay and soybean meal 43

Table 2. Passage rates of ruminal contents and digesta kinetics of wethers supplemented with a soybean oil enriched protein supplement.

Table 3. Average daily hay and supplement intakes, nitrogen retention, fecal, urine and urinary $-\mathrm{N}$ production and total tract nutrient digestibility of wethers supplemented with a soybean oil enriched protein supplement.

Experiment 2.

Table 1. Ingredient composition of supplemental treatments ${ }^{1}$ used in experiment 2 ...... 75

Table 2. Nutrient profile of supplements, and forage used in experiment 2.................. 75

Table 3. Herbage mass and herbage accumulation of each experimental plot during

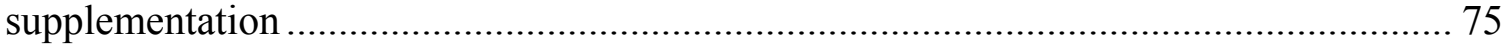

Table 4. Botanical composition of experimental plots during supplementation ............. 76

Table 5. Feeding performance of lambs on pasture and in drylots ................................. 76

Table 6. Performance of all lambs ${ }^{\mathrm{L}}$, and sacrificed wethers ${ }^{\mathrm{W}}$ while on pasture and in

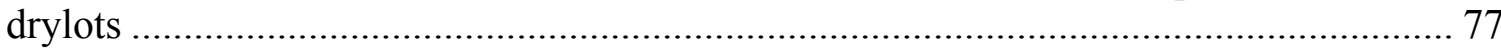

Table 7. Fatty acid profile of longissimus muscle harvested from sacrificed wethers ..... 78

Table 8. Fatty acid profile of heart tissue harvested from sacrificed wethers ................. 79

Table 9. Fatty acid profile of kidney tissue harvested from sacrificed wethers ............... 80

Table 10. Fatty acid profile of pelvic adipose tissue harvested from sacrificed wethers . 81

\section{Experiment 3.}

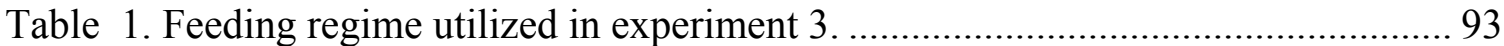

Table 2. Feed nutrient profile of feeds utilized in experiment 3................................. 93

Table 3. Feeding schedule utilized in experiment 3. .............................................. 93

Table 4. Effects of treatments on nutrient digestibility in experiment 3 ...................... 94

Table 5 Effects of experimental supplements on nutrient digestibility in experiment 394

Table 6 Effects of treatment on volatile fatty acid concentrations

Table 7 Effects of experimental supplements on volatile fatty acid concentrations 


\section{LIST OF FIGURES}

Experiment 1.

Figure 1. Effects of time of supplementation on rumen acetate concentrations in wethers supplemented with a soybean oil enriched protein supplement.................................. 45 Figure 2. Effects of time of supplementation on rumen butyrate concentrations in wethers supplemented with a soybean oil enriched protein supplement. 46 Figure 3. Effects of time of supplementation on rumen propionate concentrations in wethers supplemented with a soybean oil enriched protein supplement.

Figure 4. Effects of time of supplementation on rumen isobutyrate concentrations in wethers supplemented with a soybean oil enriched protein supplement.

Figure 5. Effects of time of supplementation on rumen isovalerate concentrations in wethers supplemented with a soybean oil enriched protein supplement.

Figure 6. Effects of time of supplementation on rumen valerate concentrations in wethers supplemented with a soybean oil enriched protein supplement. 50 Figure 7. Effects of time of supplementation on TVFA ${ }^{1}$ concentrations in wethers supplemented with a soybean oil enriched protein supplement. 51 Figure 8. Effects of time of supplementation on rumen $\mathrm{NH}_{3}-\mathrm{N}^{1}$ concentrations in wethers supplemented with a soybean oil enriched protein supplement. 52 Figure 9. Effects of time of supplementation on rumen $\mathrm{pH}$ in wethers supplemented with a soybean oil enriched protein supplement.

Experiment 3.

Figure 1. Effects of time of supplementation of soybean oil or soybean oil mixed with soybean meal on fermenter ammonia nitrogen $\left(\mathrm{NH}_{3}-\mathrm{N}^{1}\right)$ concentrations . 96 Figure 2. Effects of time of supplementation of soybean oil or soybean oil mixed with soybean meal on fermenter TVFA ${ }^{1}$ concentrations

Figure 3. Effects of time of supplementation of soybean oil or soybean oil mixed with soybean meal on fermenter $\mathrm{pH}$ 


\section{Chapter 1 INTRODUCTION}

During the latter half of the $20^{\text {th }}$ century the sheep industry in the United States and in West Virginia experienced significant declines. Many people in West Virginia abandoned sheep production as a component of economic development. A few producers in the state and scientists at West Virginia University collaborated and formed the West Virginia Sheep Management Project (WVSMP). This organization emphasizes the use of reproductive management techniques to allow out-of-season breeding of ewes. The efforts of the organization have resulted in increasing sheep numbers and marketing of specialty products, both of which can be essential for survival of the sheep industry. As the sheep industry expands, production cost would need to be limited if farmers are to remain competitive with other producers (WVSMP, 1999). Feed cost represents the greatest proportion of the annual cost of maintaining ewes and producing a pound of lamb. In West Virginia sheep production, forages are the primary raw material needed to produce saleable commodities (WVSMP, 1999). Thus, grazing and pasture management are key to cost control and profitability in sheep production in West Virginia.

The use of supplemental rations for grazing sheep may be helpful in providing daily nutrient requirements for flocks during periods of insufficient forage availability. Energy supplementation is of particular interest, especially in grass-based production systems. When increased average daily gains are targeted, low levels of supplementation with high energy rations may be effective (Canton and Dhuyvetter, 1997). Fat supplements can and are used to increase the energy density of high forage diets that are fed to ruminants (Bayourthe et al., 1993; and Palmquist, 1994). In addition, fat supplementation can effectively alter fatty acid composition of ruminant muscle and adipose tissue. Alterations in fatty acid composition of ruminant muscle and adipose tissue may alter the nutritional value of these food products (Bolte 
et al., 2002). Thus, the use of fat supplements in sheep flocks in West Virginia may benefit lamb growth and lamb quality.

However, the feeding of fat supplements is associated with reduced voluntary intake of the basal diet, negative effects on rumen microbial metabolism, and fiber digestibility (Bayourthe et al., 1993; and Palmquist, 1994). Therefore, sheep producers who choose to supplement with fat must use management strategies which avoid negative associated effects of fat supplementation. The use of rumen active fats at low levels have been recommended as an option for avoiding negative associated effects of fat supplementation. Time of offering supplemental fat each day is one aspect of the farmer's management strategy that must be decided upon. Practical times for offering daily supplement might be early morning or late evening for part time sheep production enterprises. Alternatively it may be better to divide daily dose of supplement, and offering equal portions of supplement at both times early morning or late evening. In addition, the time of supplementation should also be guided by prevalent diurnal patterns of grazing activity. Diurnal grazing patterns affect diurnal rumen metabolism, including metabolism of ingested supplemental fat. Rumen metabolism of supplemental fat affects the success of fat supplementation strategies. Hence, the time of offering a daily supplement must be practical and facilitative of enhanced fatty acid composition of ruminant product but should not be conducive to compromised rumen or total tract digestibility.

Therefore, the wise use of fat supplementation in sheep production is proposed. Research focused on the effects of time of offering a relatively low level of supplemental soybean oil to specific feeding systems when high forage rations were used is lacking. Thus the effects of the time of supplementation on rumen metabolism and fatty acid composition of lamb and ruminal 
effluent digesta were investigated and are reported in this dissertation following a relevant literature review. 


\section{Chapter 2 : LITERATURE REVIEW}

\subsection{Fats and fatty acids}

Fats consist of a wide group of compounds that are generally soluble in nonpolar or organic solvents and largely insoluble in water and polar solvents. Depending on their structure and composition fats may be either solid or liquid at normal room temperature. The words "oils", "fats" and "lipids" are used interchangeably to refer to fats, but "oils" usually refer to fats that are liquids at normal room temperature, while "fats" usually refer to fats that are solids at normal room temperature, and "lipids" is used to refer to both liquid and solid fats. Although the chemical structure varies widely, fats are generally triesters of glycerol and fatty acids. All fats consist of a variation of a basic chemical structure which contains fatty acids (hydrocarbon chains with a carboxylic acid group at one end) bonded to a backbone structure, often glycerol to form a triester with ester bonds. The specific fatty acids within a fat affect the properties of that fat (Gurr et al., 2002).

Fatty acids are aliphatic monocarboxylic acids, commonly having a chain length of 4 to 28 carbons (usually unbranched and even numbered), which may be saturated or unsaturated. The chain length influences the physical properties of the fatty acid and fats which contain these specific fatty acids. For example as chain length increases the melting point and energy content of the fatty acids also increase. Similarly, the fat's constituent fatty acids may differ in the number of hydrogen atoms that are bonded to carbon atoms within the chain, which in turn impacts physical properties such as melting point and caloric value. Typically each carbon atom is bonded to two hydrogen atoms. Such an arrangement in which carbon atoms are bonded to as many hydrogen atoms as possible, the carbons are described as being saturated with hydrogen. In contrast, adjacent carbon atoms may have a double bond between them and bond to a single 
hydrogen atom, to form an unsaturated fatty acid. Fatty acids with one double bond are termed monounsaturated and those with multiple double bonds are called polyunsaturated. Furthermore, the presence of double bonds results in creation of geometric cis or trans isomers of fatty acids which further influences the properties of any fat (Gurr et al., 2002).

Nomenclature of fatty acids is variable but has focused on the location of the double bond within a molecule. As such three systems for nomenclature are prevalent (Gurr et al., 2002);

System 1: The cis/trans-Delta-x or cis/trans $\Delta^{\mathrm{x}}$ system. Here the double bond is located at the xth carbon to carbon bond and counting is initiated from the carboxylic or delta end of the fatty acid. The cis/trans notation indicates the isomeric form of the fatty acid. Where molecules have two or more double bonds, the cis and trans notation are used repeatedly to reflect the nature and amount of each isomeric forms, for example, cis, cis $\Delta^{9} \Delta^{11}$ or cis, trans, $\Delta^{9} \Delta^{12}$.

System 2: The omega-x or n system. This system indicates that the double bond is located on the xth carbon to carbon bond, when counting began from the $\mathrm{n}$ or methyl carbon end of the fatty acid chain.

System 3: The IUPAC. This system begins counting at the carboxylic end and cis double bonds are labeled $\mathrm{Z}$ and trans double bonds are labeled $\mathrm{E}$ (Gurr et al., 2002).

Throughout this review the omega-x or $\mathrm{n}$ system is predominately used but the cis/transdelta-x or cis/trans $\Delta^{\mathrm{x}}$ system shall be used occasionally. 


\subsection{Fat sources}

A detailed review of the various fat sources commonly utilized in formulating ruminant diets was recently compiled by Felton, (2001). A summation of part of this review follows. Felton, (2001) reported that although fat sources differ widely, the majority of fat sources are derived from plant, animal and commercially manufactured sources. The report indicated that forages were probably the most common fat source that ruminants were likely to consume. Felton, (2001) quoted an N.R.C., (1996) report which stated that the ether extract of the common forages fed to ruminants ranges between 1.0 and $5.5 \%$. Reportedly, the lipid fraction of fresh forages consists predominantly of galactolipids and phospholipids and forages are typically high in unsaturated fatty acids; linolenic (18:3n6), linoleic (18:2n6), and oleic acids (18:1n9). In contrast, Felton, 2001 cited N.R.C., (2001) report which stated that grains are typically much higher in ether extractable lipids (1.4 to 41\%). Furthermore, the fatty acids in grains are predominately found as triglycerides with minor amounts of mono- and diglycerides and phospholipids. The fatty acids composition of grains varies widely but typically will be highly unsaturated (Felton, 2001).

Animal fats are usually quite variable in lipid and fatty acid composition. Among some of the more common animal fat sources, an increasing order of unsaturation exists for tallow, yellow grease, lard/choice grease and fish oil. Generally, animal fat sources tend to be richer in long chain fatty acids, especially those of 20 carbons or more, than the plant sources. Animal fats might be the only natural sources to contain substantial quantities of arachidonic (20:4n6), eicosapentaenoic (20:5n3) and docoshexaenoic (22:6n3) acids. In contrast to plant derived lipids, animal derived lipids may contain substantial amounts of mono- and diglycerides and free fatty acids in addition to triglycerides (Felton, 2001). 
Plant and animal fat sources are considered rumen degradable because lipolysis occurs in the rumen to release free fatty acids which can then become altered by rumen microbes. Due to the latter, plant sources might affect rumen metabolism of other dietary constituents but the degree of alteration of rumen activity, or susceptibility to microbial hydrolysis differ widely. Historically, the inhibitory effects of fat on ruminal microbial metabolism have been a deterrent for increased incorporation of fat in ruminant rations. However, feed manufacturers have developed fat products which are classified as rumen inert sources. These rumen inert sources have chemical properties which permitted increase consideration of fat inclusion in ruminant diet. The chemical properties of these rumen inert fat products allow passage through the rumen relatively unscathed by interaction of the fatty acids with rumen microbes or feed particles and consequently adverse effects on rumen metabolism are reduced. Examples of the manufactured fat sources include highly saturated triglycerides or free fatty acids (i.e. Max-FatR or hydrogenated tallow and Energy Booster 100R, respectively), cationic salts of fatty acids (MegalacR) and physically modified (i.e. "prilling"; AlifetR) forms (Felton, 2001).

\subsection{Management strategies for feeding fat}

Feeding management strategies employed to improve ruminant food products fatty acid composition include feeding high concentrate diets (Kucuk et al., 2001), utilizing ruminal escape fats (Scollan et al., 2003; Lee et al., 2004), oilseed inclusion (Rule and Beitz; 1986, Chang et al., 1992; Felton and Kerley, 2004 a, b), and feeding free plant oils (Lough et al., 1992; Solomon et

al., 1992; Kucuk et al., 2004). The successfulness of these feeding strategies might be affected by diurnal rumen metabolism. Diurnal changes in grazing activity of ruminants in response to environmental temperatures, demand for other activities such as rumination and resting (Rook et 
al., 1994), diurnal changes in nutrient composition of pasture (Orr et al., 1997) and rumen metabolites (Van Vuuren et al., 1986) can affect diurnal changes in rumen metabolism.

Feeding supplements have an impact on post-prandial variation in rumen activity and hence, the timing of supplementation has been viewed as critical to success of supplementation strategies. Indeed, the importance of time of supplementation as an aspect of feeding management has been investigated for energy (Adams, 1985), protein (Barton et al., 1992; Robinson et al., 1997; and Gekara et al., 2005) and amino acid (Wiley et al., 1991; and McCracken et al., 1993) supplements. The results of these studies generally suggest that the time at which the supplement is ingested could impact post-prandial variation of rumen activity (presumably including ruminal biohydrogenation of ingested fatty acids), as well as total tract nutrient digestion and dry matter intake (DMI). Furthermore, these studies have indicated the possibility for improving the efficiency of digestion and metabolism of specific nutrients while not adversely affecting digestion of other nutrients.

A review of the published literature pertaining to supplementation of dietary fats reveals variation in the time at which supplement is introduced relative to the time at which the complete or part of the basal diet is introduced. Various modes of fat supplementation seem to be employed in experimental methodology. Metabolism trials generally use single or split oral administrations, intra ruminal or duodenal administrations coupled with feeding of a basal diet in either single or split equitable or inequitable quantities. Animal performance trials as compared to metabolism trials generally deliver the supplement orally via top dressing of basal diet, incorporation into total mixed rations, or mixed into the concentrate fraction of the ration and also offered in either single or split equitable or inequitable quantities. The forage to concentrate ratio of the basal diet has also been emphasized as an important factor affecting fat 
supplementation strategies and will be reviewed. In addition, it is apparent that researchers have emphasized the use of rumen inert fats (Scollan et al., 2003; Lee et al., 2004), and oilseed inclusion (Chang et al., 1992; Felton and Kerley, 2004) within recent years because of advantages that they present and this literature review will incorporate studies using these fat sources. It is also apparent that various time points have been used for introduction of fat supplements but the effects of delaying introduction of fat has not been widely reported. Hence, it seems relevant to review the literature to evaluate the possible implications of delayed supplementation on the successfulness of fat supplementation strategies.

\subsection{Diurnal variation in ruminal microbial population; implications on fat supplementation} strategies

The rumen microbial population is composed of a complex mixture of bacteria, protozoa, fungi, and yeasts (Yokoyama and Johnson, 1988, and Dehority, 2003). Within each of these groups a collection of morphologically and biochemically diverse species exists and their carbohydrate substrate utilization spectra overlap (Leedle et al., 1982). This diverse and versatile microbial population is important to ruminant animals' ability to consume a wide variety of feedstuffs (Yokoyama and Johnson, 1988, and Dehority, 2003). Indeed, the species composition of the rumen microbial community is responsive to variations in feeding regimens, particularly variations in dietary forage and concentrate ratio. The microbial species and cellular composition have also been shown to be affected by feed intake level (Hungate, 1975), frequency of feeding (Dehority, 2003), the postprandial time at which the rumen was sampled (Bryant and Robinson, 1968) or in-vitro incubation time (Dehority, 2003). 
Leedle et al. (1982) suggested that the diurnal variation of the carbohydrate specific bacterial groups, if existent, would follow the fermentation of the major feedstuff components. Presumably this also applies to the entire rumen microbe population. An understanding of the latter suggestions had previously led to development of a theoretical scheme for diurnal ruminal fermentation pattern. The pattern was based upon relative solubility of feed components and microbial fermentative pathways observed for the major carbohydrate components of most rations after a once daily feeding (Hungate, 1975, Johnson, 1976). This scheme suggests that the highly soluble materials (sugars, some proteins), are rapidly fermented postprandial and are associated with a high peak in microbial activity, followed by the fermentation of less-soluble materials such as starches and some pectins, with a lower peak in microbial activity, then a third peak, representing pectin and dextrin fermentation, is followed by degradation of the rather insoluble materials of the plant cell wall complex (hemicelluloses and celluloses). Therefore the hemicelluloses and cellulose materials undergo fermentation after a relatively long ruminal retention time with low and broadly based peaks of associated microbial activity (Leedle et al., 1982). Diurnal variation of the total rumen microbe population (Bryant and Robinson, 1968) and within the bacterial fraction of the major carbohydrate fermenting groups (e.g., cellulolytic, pectinolytic) in animals fed high-forage or high-concentrate diets at similar intake level has been reported (Leedle et al., 1982). Diet effect on diurnal total bacterial numbers were not observed throughout the day but the number of viable bacteria declined 40 to $60 \%$ postprandial and increased to a maximum at $16 \mathrm{~h}$ post-feeding. Changes occurred within the carbohydrate specific-subgroups of the total bacterial populations and some of the changes were consistent with the predicted scheme (Hungate, 1975, Johnson, 1976) for fermentation of ruminal carbohydrate feedstuffs. Leedle et al., (1982) concluded that the data was consistent with the 
versatility and constancy of the rumen as a stable, mature microbial system. Arguably, the impact of different feeding regimens upon diurnal patterns of bacteria population dynamics is dependent upon the divergence between specific regimens, including the use of supplemental fat and the time at which supplemental fat is offered relative to first offering of the basal diet.

\subsection{Once a day feeding}

The range of studies performed wherein fat supplements have utilized a range of research techniques, and different fat sources. More recently these studies use a once a day feeding strategy. In addition, these studies seemingly acknowledge potential impact of fat supplements on patterns of post-prandial ruminal digestion and kinetics but by sheer nature of design overlook the importance of latter to ruminal biohydrogenation and the successfulness of attempts aimed at improving tissue and milk fatty acid composition.

Early on the need for achieving ruminal protection of supplemental fat was determined. Hence, the use of certain fat sources and protected fats has been promoted within recent times. Perceivably, the success attained when protected fats are used may be further complemented by the use of low forage diets. The increase use of protected fat sources in low concentrate diets favor the once a day feeding strategies, principally because it avoids ruminal modification of fats but some ill effects still occur. Alternatively, the use of rumen active fat sources in a strategic manner might achieve comparable results if supplements are fed at a delayed time relative to the basal meal. Furthermore, for grazing ruminants or ruminants fed a high forage diet once per day delayed fat supplementation may represent a more successful option.

In a performance trial, Bolte et al. (2002) investigated the effects of feeding 5\% supplemental fat on fatty acid content of muscle and adipose tissue of lambs. Lambs were fed a 
basal diet (control), a diet containing cracked high oleate (76\% 18:1) safflower seeds (oleate) or a diet with cracked high-linoleate ( $78 \% 18: 2$ ) safflower seeds (Linoleate) as a total mix ration once a day at $700 \mathrm{~h}$. Fat treatments increased tissue 18:1 $1^{\text {trans-11 }}$ and CLA content while not affecting feed efficiency, growth performance or carcass characteristics. However, daily feed intake differed amongst treatments. Daily feed intake was lower $(\mathrm{P}=0.02)$ for oleate $(1.4 \mathrm{~kg} / \mathrm{d})$ than for linoleate supplemented $(1.5 \mathrm{~kg} / \mathrm{d})$ lambs. The lower feed intake observed in oleate supplemented lambs may have been attributable to reduced rumen or total tract digestibility but this was not reported. Similarly, the daily feed intake of the control lambs was not included in the report even though these researchers assumed that these fat enriched rations may reduce digestibility. In contrast, Wachira et al. (2002) fed lambs diets containing unprotected fish oils and reported reduced feed intake. This agreed with previously reported trends in sheep (Gulati et al. 1999) and dairy cows (Doreau and Chilliard, 1997). The decrease in intake upon feeding fish oil was attributed to a significant reduction in fiber digestion and microbial growth in sheep (Wachira et al., 2000) fed a similar diet to what was fed by Wachira et al. (2002).

Daniel et al. (2004) fed fat supplemented diet to sheep once per day and effectively altered fatty acid composition of sheep tissues. This study did not report DMI even though treatment affected growth rates, carcass weights, adipose tissue weights and adipocyte volume. Diurnal plasma insulin concentrations differed with treatment and might have been related to DMI, and ruminal digestion patterns. Lambs fed fat supplemented concentrate diet showed constantly high insulin concentrations throughout the day while those fed high forage diet showed an early postprandial increase which rapidly returned to concentrations observed prior to the introduction of feed for the rest of the day. These authors had previously shown that insulin significantly increases the expression of ovine SCD and the synthesis of monounsaturated acid 
from acetate in cultured ovine adipose tissue explants. Thus the increase SCD activity might be indirectly related to diurnal feed intake and digestion patterns. Furthermore, treatment affected abomasal fatty acid composition, suggesting differences in ruminal digestion and kinetics which in turn may have been related to diurnal DMI and microbial population dynamics.

The potential for fat supplements to impact DMI, ruminal digestion and ruminal biohydrogenation when feeding rumen inert fats was illustrated by Harvatine and Allen, (2006 a, b, c). Using a series of 3 experiments the effects of fat supplements differing in fatty acid saturation were evaluated. Eight ruminally and duodenally cannulated cows were used in a replicated 4 x 4 Latin square design. Treatments were a control diet without added fat, or fat supplemented diets containing $2.5 \%$ fatty acid from saturated, partially unsaturated or an intermediary mixture (50:50) of saturated and unsaturated fatty acid. Both saturated and unsaturated fat source were bypass fats suggesting that major effects of fat supplementation on digestive activity would presumably be postruminal. Concentrate rich diets were fed as total mixed rations offered once per day at $0900 \mathrm{~h}$.

The addition of fat supplements decreased DMI, and increasing unsaturated fat supplementation linearly decreased intake amongst the fat supplemented treatments. Intake of other nutrients including NDF, starch and crude protein followed the same response pattern. Decreasing meal size and decreased feed intake were associated with increased unsaturated fatty acid flow to the duodenum. Increased saturated fatty acid flow to the duodenum increased rumination time per day by increasing rumination bout length. Relling and Reynolds, (2007) also observed decreases in intake in lactating dairy cows fed rumen inert fats as the degree of saturation declined. This decrease in DMI was associated with near linear increases in glucagon like peptide-1 (GLP-1) and CCK but decreased insulin concentrations for at least $7 \mathrm{~h}$ after the 
provision of the daily rations. It is suggested that decreases in DMI may not occur if fat was introduced in smaller doses periodically to avoid elevation of GLP-1 and CCK together with depression of insulin concentrations.

Despite the use of rumen protected fat sources, a low percent of added fat, and a concentrate rich ration, treatment effects on ruminal digestion kinetics and site of digestion were observed in a study of Harvatine and Allen, $2006 \mathrm{c}$. Saturated fat supplementation linearly decreased ruminal digestibility of DM, organic matter and NDF. The reduction in ruminal NDF digestibility occurred due to a linear decrease in digestion rate and a linear increase in passage rate of potentially digestible NDF with increasing saturated fat supplement. Despite adverse effects of supplemental fat on ruminal digestion, total tract digestibility did not differ amongst treatments because of compensatory postruminal digestion. The effects of supplemental fat on ruminal activity might have also extended to ruminal biohydrogenation as indicated by an unsaturated fat supplement induced milk fat depression which was observed. This milk fat depression together with decreased milk CLA concentrations indicates reduced duodenal flow of biohydrogenation intermediates which might be due to effective protection or more complete biohydrogenation of PUFA. Both protection and biohydrogenation of PUFA were affected by digesta passage rate which decreased linearly with increased unsaturation of the fat supplement (Harvatine and Allen, 2006 a). Hence, it might be beneficial to feed fats in small quantities at increased frequencies throughout the day, or to allow for greater animal selectivity even when rumen protected fat sources are used to supplement concentrate rich diets.

Cooper et al. (2004) fed several different fats with concentrate based diets. Five supplements used were; linseed oil, fish oil, fish oil and algae, a protected lipid containing a mixture of linseed, sunflower seed and soybean encapsulated in formaldehyde treated protein 
and a protected lipid supplement and algae mixture. The feeds were offered once daily at $0900 \mathrm{~h}$ at a rate of $110 \%$ of ad libitum intake. The effectiveness of each fat source in altering the fatty acid composition of lamb was variable. Greatest success was achieved with protected linseed, sunflower seed and soybean encapsulated in formaldehyde treated protein combined with algae. There was no effect of type dietary fat on intake or growth performance. These results agree with other research that have compared linseed with fish oil in sheep (Demirel et al., 2004) and growing cattle (Scollan et al., 2001). Two of these studies (Cooper et al., 2004, Demirel, et al., 2004) utilized a concentrate rich diet while the study of Scollan et al. (2001) utilized a forage based diet. Similar to the study of Wachira et al. (2002), in the study of Scollan et al. (2001), forage was fed at one time $(1400 \mathrm{~h})$ but contrastingly the fat enriched concentrate was fed in two equal portions at 0900 and $1630 \mathrm{~h}$. This strategy may have facilitated increase ruminal passage rate of supplemental fats and reduced adverse effects of supplemental fat upon fiber digestion and feed intake. The use of oilseeds or protected lipids by Cooper et al. (2004) as the fat source of each diet probably accentuated the beneficial effects of a high concentrate diets and enhanced the successfulness of a fat supplementation strategy. Higher ruminal passage rate for concentrate diets together with the enhanced escape of protected oilseeds from ruminal modification would be instrumental in effecting changes in fatty acid composition.

The benefits of feeding protected lipid sources with high concentrate diets once a day were also reported by Lee et al. (2004) and Wynn et al. (2006). These two studies demonstrated the effectiveness of increased dose of supplemental fat in enhancing fatty acid composition of ruminant tissue while avoiding disruption of ruminal digestion because these fat sources were protected. The use of relatively high levels of protected fat presumably permits a constant flow of exogenous and endogenous fat to the duodenum throughout the day, which allows for better 
absorption and incorporation into tissues. The use of unprotected fat sources at low or moderate levels may also be effective if the fat is fed twice daily or at a delayed postprandial period even with high forage diets if the flow of fatty acids to the duodenum occurs at a rate that allows efficient absorption and assimilation into tissues. Suggestively, modification of fat supplementation strategy may enhance the level of success attained when the basal diet is offered once daily.

Modification of a once a day feeding strategy was used in two studies (Ponnampalam et al., 2001 and Ponnampalam et al., 2002) where fat supplements were fed. In both studies fish meal was offered in separate containers. In addition, in the second study the fish meal was offered at 2 day intervals (i.e., 2 day allowance), indicating that anticipated problems with consumption of the supplement may have guided the feeding strategy that was used by researchers. The palatability of fish oil supplement and its propensity for being rumen active were probably also factors dictating the supplementation strategy employed in these aforementioned studies and other similar studies (Doreau and Chilliard, 1997; Wachira et al., 2000; Wachira et al., 2002). 


\subsection{Effects of delayed feeding of fat supplement}

A preliminary review of the literature reveals several experiments in which feeding strategy has been modified so either a portion or entire supplement is fed at a delayed time relative to the introduction of the first meal. In this section of the literature review, implications of delayed supplementation strategies are focused upon. Experiments involving delayed supplementation of rumen inert and rumen active fats shall be reviewed separately.

\subsection{Delayed feeding of rumen inert fat supplements}

The effects of the addition of rumen inert calcium salts of fatty acids to diets that differed in NDF content on milk yield and composition, nutrient digestibility, and concentrations of selected blood metabolites in early to midlactation Holstein cows was evaluated by Canale et al., (1990). Treatments were (DM basis): (1) $0 \%$ fat with $31 \% \mathrm{NDF}$; (2) $2.56 \%$ fat with $31 \% \mathrm{NDF}$; (3) $0 \%$ fat with $25 \% \mathrm{NDF}$ and (4) $2.56 \%$ fat with $25 \% \mathrm{NDF}$. Based on DM basis diets 1 and 2 contained $70 \%$ alfalfa silage and $30 \%$ concentrate, and diets 3 and 4 contained $50 \%$ alfalfa silage and $50 \%$ concentrate. Fat was added to the grain portion of diets 2 and 4 . All diets were fed as total mixed rations to allow for 5 to $10 \%$ refusals in two portions daily at 0630 and $1400 \mathrm{~h}$, thus effectively delaying the administration of approximately half of the supplement. There were no significant interactions between fat supplementation and diet NDF content for any variable and neither DMI nor net energy of lactation was affected by fat supplementation. Grummer, (1988) also fed a rumen inert fat supplement using a delayed feeding strategy at $12 \mathrm{~h}$ intervals (1000, and $2200 \mathrm{~h}$ ) and observed neither an effect of treatment on DMI nor net energy of lactation. Fat supplementation has been previously shown to reduce milk protein percentage but increase yields of milk, milk fat, and 4\% fat corrected milk (Canale et al., 1990). Although fat supplementation reduced dry matter digestibility when dairy ewes were fed calcium soaps of 
fatty acids at $10 \%$ of basal diet in three equal meals at 0800,1500 and 2200 , voluntary intake of roughage was not significantly reduced. The ewes fed the protected fat also tended to produce more milk, protein and milk fat (Perez et al., 1997). In contrasts, Harvatine and Allen (2006 c), also supplemented fat at $2.5 \%$ using a once per day feeding strategy and observed unsaturated fat induced milk fat depression. The degree of unsaturation of supplemented fat used by Canale et al. (1990) was not reported and could not be compared to that of the supplement used by Harvatine and Allen (2006 c), to accurately assist in comparing effects of supplemental fat in both studies. However, assuming similar degree of saturation, it is possible that introduction of half the supplement at a delayed time promoted better rumen metabolism or duodenal fatty acid flow and digestion. The reports of Grummer (1988) and Perez et al. (1997), supports this theory because feeding a rumen inert fat supplement using a delayed supplementation strategy did not induce milk fat depression. Digestibility of fat postruminally, increases as the degree of unsaturation of fatty acids increase (Wachira et al., 2000; Oldick and Firkins, 2000) and presumably as the rate of digesta flow through the small intestine decreases. In contrast, in the study of Harvatine and Allen, (2006 c) where fat was supplemented using a once per day feeding strategy the efficiency of conversion of digestible energy to milk tended to decrease linearly with increasing unsaturated fat supplement. The primary reason suggested for the decline in digestible energy conversion was decreased DMI and energy intake associated with the feeding of unsaturated fat supplements.

Harvatine and Allen, $(2006 \mathrm{c})$ indicated that increased passage of unsaturated fatty acids to the duodenum has chemostatic effects which effectively slow ruminal contractions, and outflow of dietary and endogenous fatty acids. Thus enhanced ruminal biohydrogenation of dietary and endogenous fatty acids is facilitated (Perez et al., 1997) and ruminal digestion is 
probably reduced. The delayed introduction of half of the supplement (Grummer, 1988 and Canale et al., 1990) or increase frequency of feeding to three or four times per day (Perez et al., 1997; Schauff et al., 1989) rather than one time (Harvatine and Allen, 2006 c) has been associated with absence of adverse effects on ruminal and total digestion and DMI (Canale et al., 1990, Schauff et al., 1989). Furthermore, there was a trend for increased apparent digestibility of fat (Canale et al., 1990 and Perez et al., 1997) and apparent digestibility of total lipid (Grummer, 1988) with calcium salts of fatty acids supplementation. This improved digestibility of total lipids suggests that the added fat might be more digestible than the endogenous lipids of the unsupplemented diet. Perceivably, delayed supplementation increased control of supplement intake which led to enhanced digestibility.

In a similar manner Bayourthe et al. (1993) did not observe effects of feeding protected fat supplement at the 5, 10, or even $20 \%$ level on ruminal degradation of DM, ADF, and NDF after $16 \mathrm{~h}$ in the rumen. Additionally, neither DM, ADF and nitrogen disappearance differed amongst dietary treatment within $24 \mathrm{~h}$ as observed in previous studies where delayed supplementation was also used (Grummer, 1988, and Schauff et al., 1989). Absence of protected supplement induced differences on in-vitro fermenter $\mathrm{pH}, \mathrm{NH}_{3}-\mathrm{N}$, and VFA concentrations was also reported (Bayourthe et al., 1993). Digestibility of DM, ether extract and nitrogen were enhanced when protected supplement was fed at $20 \%$ level to mature sheep (BW $=60 \mathrm{~kg}$ ) housed in individual metabolism crates and offered daily feed in equal portions at 0800 and 1600 h. These observations all indicate effects of rumen escape when delayed supplementation strategy was used.

Enhancing effects of feeding rumen escape fats using a delayed supplementation strategy on tissue fatty acid composition was evident in a study of Scollan et al. (2003). Feeding of 
protected lipid was associated with enhanced $18: 2 \mathrm{n}-6$ and $18: 3 \mathrm{n}-3$, polyunsaturated to saturated fatty acid ratio value which resulted in beef with a higher content of polyunsaturated fatty acid and lower saturated fat. Proportions of $18: 2 n-6$ and $18: 3 n-3$ in muscle were much higher than levels achieved using unprotected lipids in a previous study conducted by this research group (Scollan et. al., 2001). Notably, in the earlier study researchers also used a delayed supplementation strategy where supplement was offered in two equal portions at $0900 \mathrm{~h}$ and $1630 \mathrm{~h}$. In the second experiment the entire fat supplement was offered at a delayed time, a strategy which may have enhanced ruminal bypass and the efficiency of transfer of dietary PUFA from diet through to the longissimus thoracis muscle. Extension of the foregoing theory may also explain how feeding oil seeds using a delayed strategy enhance ruminal escape of PUFA. Indeed, digestibility of DM, OM, starch and GE was increased, lipid digestibility was unaffected (Andrae et al., 2000) and intramuscular lipid deposition enhanced (Andrae et al., 2001) by supplementing with high oil corn using a delayed strategy.

\subsection{Delayed feeding of rumen active fats}

The effects of feeding free oils on rumen and intestinal digestion has been explored (Jenkins, 1993) and is well represented in a study by Ikwuegbu and Sutton, (1982), who investigated the effects of varying the amount of linseed oil (LSO) supplementation on rumen metabolism and nutrient flow in ruminally and duodenally cannulated sheep. Sheep were fed a basal diet of hay and concentrates (33:67) with or without supplement $(13,26$, or $40 \mathrm{ml} \mathrm{LSO} / \mathrm{d})$ in two equal portions at 0600 and $1800 \mathrm{~h}$. This study showed that reductions in ruminal digestion occurring with high levels of oil supplementation can be compensated by hindgut digestion. The reductions in ruminal digestion manifest because free oils affect microbial populations. Effects 
of high levels of free oil supplementation were suggested to be decreases in ruminal protozoa population and increased bacterial protein synthesis. These results were in agreement with the work of Oldick and Firkins, (2000) which suggested that free oils increase the efficiency of bacterial protein synthesis. However these results are contrary to the work of Wachira et al. (2000) which stated that addition of highly unsaturated free oil can depress both microbial nitrogen production and microbial efficiency. Ikwuegbu and Sutton (1982) concluded that the net result of free oil supplementation on bacterial protein synthesis would be variable and difficult to predict. Indeed, the impact of the low forage to concentrate ratio, coupled with the delayed feeding of half of the basal diet and supplement on microbial metabolism and population dynamics seems interesting. The questions that arise are whether the quantity of oil fed per day is less critical than the quantity introduced to the microbial population per unit time or at what point in the population cycle is the oil being introduced. The digestibility of the basal ration, especially the concentrate fraction and the time it is introduced/ frequency of feeding augment microbial population and the supplementation of oil further modify the microbial population dynamics.

In a related study Ueda et al. (2003) questioned the impact of the low forage to concentrate diet on the results obtained by Ikwuegbu and Sutton, (1982). These researchers also investigated the effects of linseed oil (LSO) supplementation on ruminal digestion but utilized cannulated dairy cows, and a varied forage to concentrate ratio (F:C) of daily rations. Treatments were; a forage rich diet without linseed oil $(\mathrm{F}: \mathrm{C}=65: 35)$, with linseed oil $(\mathrm{F}: \mathrm{C}=$ 65:32, 3\% LSO), a concentrate rich diet without linseed oil ( $\mathrm{F}: \mathrm{C}=35: 65)$, or a concentrate rich diet with linseed oil ( $\mathrm{F}: \mathrm{C}=35: 62,3 \% \mathrm{LSO})$. Hay was given without chopping as the sole source of forage and LSO was mixed into the concentrate when required. Cows had ad libitum 
access to the diets but hay and concentrates were offered separately as had been done by Ponnampalam et al. (2001; 2002). All feeds were offered in 3 equal portions at 0900, 1330, and $1700 \mathrm{~h}$ presumably to control and enhance intake. Consequently, LSO treatment did not affect DM or OM intake possibly because of the relatively low level of supplementation (3\%) and or the supplementation strategy that was used in this study. In fact, ruminal NDF digestibility was increased with supplementation of LSO to the forage rich diet but decreased with supplementation to the concentrate rich diet. Ruminal ADF digestibility followed the same trend as ruminal NDF digestibility. Both ruminal OM and fiber digestion was also increased by LSO supplementation of the forage rich diet but not for the concentrate diet. The positive effects of free oil supplementation on $\mathrm{OM}$ and fiber digestion were consistent with other reports where supplement was continuously infused into the duodenum (Doreau and Chilliard, 1997) or offered in 12 equal portions per day (Wachira et al., 2000) but contrary to the report of Ikwuegbu and Sutton, (1982). Ueda et al., (2003) explained this contradiction by suggesting that an inadvertently higher supply of rumen degradable protein from soybean meal introduced into the LSO supplemented forage rich diet might have enhanced ruminal microbial activity, and resulted in increased ruminal fiber digestibility. Assuming the latter to be true the benefit of distributing this soybean meal protein over three meals along with the LSO supplement is supported by the suggestion that feeding proteins in conjunction with fat improves the efficiency utilization of proteins (Cuitun et al., 1975).

Furthermore the increased ruminal digestibility observed with the forage rich diet when LSO was supplemented was associated with increases in total tract digestibility of OM, NDF, and ADF. Increase total tract digestibility was also observed with the LSO supplemented high concentrate diet despite the decreases in ruminal fiber digestibility that occurred. This large 
intestine compensatory digestion had also been reported by Ikwuegbu and Sutton, (1982) where LSO enriched concentrates were also fed using a delayed strategy. In contrast, LSO supplementation had no significant effects on ruminal or total tract digestibility of starch (Ikwuegbu and Sutton, 1982 and Ueda et al., 2003) which may also be the end result of enhanced digestive activity arising from use of a delayed supplementation strategy. However, there was an interaction between forage: concentrate ratio and LSO supplementation for starch digestion. Ruminal starch digestibility decreased with LSO supplementation to the high forage diet, whereas it increased with the concentrate rich diet (Ueda et al., 2003). The impact of supplementation and potentially different digesta passage rates of both diets on microbial digestion might explain the observed interaction effects. Indeed, a greater amount of concentrate in the diet decreased the proportion of acetate and isovalerate, but increased propionate, valerate and caproate and supplementation with LSO decreased ruminal protozoal numbers only with the concentrate rich diet (Ueda et al., 2003). The frequency of feeding a basal diet and fat supplements may influence dynamics of microbe population, ruminal digestion, ruminal biohydrogenation and possibly the success of any fat supplementation strategy.

In a companion paper (Loor et al., 2004 a) to that of Ueda et al. (2003) data on duodenal fatty acid flows showed increased flow of CLA with LSO with both the high and low concentrate diet. In a subsequent study Loor et al. (2004 b) reported the diurnal profiles of CLA and trans fatty acids in ruminal fluid from cows fed a high concentrate diet supplemented with fish oil, linseed oil, or sunflower oil. A moderate effect on concentration of trans-18:1 coupled with accumulation of 18:2 intermediates and a decrease of 18:0 over time was observed. These observations indicated effects of oil supplementation (Loor et al., 2004 b) on ruminal biohydrogenation. A greater concentration of ruminal entodinium spp. which they observed in a 
prior study with fish oil (Ueda et al., 2003) may have to some degree caused the loss of bacteria carrying out the reduction of trans-18:1 to 18:0. Similarly, effects of fat supplementation on microbial biohyrogenation may have also been observed in other studies (Kucuk et al., 2001, 2004, 2007) where similar supplementation strategies were used. This type of supplementation strategy was used by Boles et al. (2005) to supplement sheep diets with safflower oil, up to 6\% of the diet. The result of such supplementation was increased levels of unsaturated fatty acids and CLA in the lean tissue, without adverse effects on growth performance, carcass characteristics, or color stability of lamb. More recently Kim et al. (2007) used this delayed supplementation strategy to effectively reduce the n-6:n-3 ratio in ruminal digesta, liver and muscle of lambs. This reduction was associated with absence of effects on DM intake, and apparent digestibility of DM, ether extract, NDF, or ADF but increase apparent digestibility of CP.

\subsection{Intestinal infusions}

Intestinal infusions represent a useful experimental technique for selecting the time and site of introduction of supplemental fat. Ruminal infusions effectively simulate oral consumptions of rumen active and inactive fats, while abomasal and duodenal infusions simulate effects of feeding rumen inert fats or postruminal flow of dietary and endogenous fats. A review of several experiments that utilized these techniques and implications of the time of supplementation on the results of these studies follow.

The effects of ruminal or duodenal infusion of soybean oil on OM intake, ruminal fermentation, NDF digestion, and duodenal nutrient flows was examined in ruminally and duodenally cannulated beef heifers consuming grass hay (Krysl et al. 1991). Treatments were 
either no supplement (control), $150 \mathrm{ml}$ of duodenally infused soybean oil, or $150 \mathrm{ml}$ ruminally infused oil twice daily to each heifer. Heifers were fed chopped grass hay ad libitum offered in two allotments at 0700 and 1900 daily. Supplement was infused at 0700 and 1900 daily. Forage organic matter, ADF, NDF, and N intake were not affected by soybean oil infusion. Similarly, supplemental fat effects on ruminal OM, ADF, and NDF digestibility were not observed. Even though total tract OM digestibility was reduced by ruminal infusion neither ruminal nor duodenal infusions of soybean oil effectively altered total tract digestion of ADF, and NDF. The absence of effects of fat supplementation on intake and digestion might be attributable to the low level of fat supplementation used (Jenkins and Palmquist, 1984) and the splitting of the oil supplement into two equal portions administered $12 \mathrm{~h}$ apart. Effects of oil infusion on microbial population and fermentative digestion were evident but differed with site of infusion. Both duodenal and microbial nitrogen flows, and microbial efficiency were lower when soybean oil was infused duodenally rather than intraruminally or not at all. Ruminal $\mathrm{pH}$ was lower with ruminal infusions than with either control or duodenally infused treatments and, although ruminal $\mathrm{NH}_{3}-\mathrm{N}$, total VFA, butyrate and acetate were not affected by treatments, propionate concentration was highest in ruminally infused heifers. As a result the acetate to propionate ratio was lowest for ruminally infused heifers. Collectively, the data suggested minimal benefits of ruminal infusion of soybean oil in this experiment where the supplement was administered in equal portions at $12 \mathrm{~h}$ intervals.

Studies involving the continuous infusion of oils postruminally supposedly simulate the escape of fats from the rumen and are useful in experiments that investigate the effects of fat supplementation on DMI. In one such study Benson et al. (2001) examined the effects of abomasal long chain fatty acids (LCFA) infusion on feed intake, rumination, patterns of feeding, and milk yield and composition. Presumably, postruminal infusions ensured that direct negative 
effects of supplemental LCFA on ruminal microbes or microbial digestion were avoided. Hence, reduced DMI that was observed when oil was infused into the abomasum would be linked to energy homeostasis mechanisms (Harvatine and Allen 2004 a; Relling and Reynolds, (2007). The latter is substantiated by the observation that reductions in estimated feed metabolizable energy intake were approximately equal to the energy in infused fat. Assessment of the circadian patterns of feeding behavior showed that the reductions in daily DMI caused by continuous fat infusion occurred during the afternoon (1230) and evening (2230), but intake following the morning (0830) feeding was unaffected. The authors suggested that the latter might reflect differences in the mechanisms regulating feeding behavior and appetite during the course of the day. Hence, in this experiment the reduction in intake occurred during the evening and night periods because cows were continuously supplied and probably periodically oversupplied with energy from continuous oil infusion and dietary and endogenous nutrients. Therefore if periodic oversupply of energy is avoided then reductions in DMI may be averted. Feeding a bypass fat supplement at a delayed time may have averted not only adverse effects on rumen digestion, but also avoided or reduced declines in DMI.

Results of the Benson et al. (2001) study agreed with results of other trials involving postruminal fat infusion in suggesting that polyunsaturated nonesterified fatty acids have very potent effects on DMI. However, the observations in this study led Benson et al. (2001) to question the role of CCK in hypophagic mechanisms. Postruminal infusion of oil to lactating dairy cows elicited increased plasma CCK concentrations and reduced DMI when a basal ration was fed once a day (Chelikani et al., 2004) but not when a ration was offered in two (Litherland et al., 2005) or three (Benson and Reynold, 2001b) equal portions throughout the day. Similarly, feeding rumen inert fat once per day to dairy cows increased plasma CCK concentrations (Choi 
and Palmquist, 1996; Choi et al. 2000; Relling and Reynolds, 2007). There may be a role for other dietary factors such as protein supply (Choi and Palmquist, 1996; Benson et al., 2001b) in the regulation of CCK induced hypophagia. Hence, the delayed delivery of basal ration impacts digestion, postruminal flow of dietary and endogenous nutrients including lipids which probably act in cohesion with postruminally infused fats to alter CCK concentrations, DMI, digestion, and ruminal biohydrogenation of ingested fatty acids.

\section{Summary}

In contrast to the availability of literature on the influence of time of supplementation of energy and protein, there is a scarcity of similar literature addressing the influence of time of fat supplementation on ruminant digestion and fatty acid composition of ruminant products. Albeit, the available literature suggests that time of fat supplementation might affect DMI, rumen metabolism, total tract digestion, fat digestion, fatty acid biohydrogenation and possibly ruminant product fatty acid profiles. 


\section{Chapter 3 : EXPERIMENT 1}

The effects of time of supplementation of a fat enriched protein supplement on post-prandial rumen activity and total tract nutrient digestion.

\subsection{ABSTRACT}

The effects of time of supplementation of a fat enriched protein supplement on postprandial rumen activity and total tract nutrient digestion of lambs fed orchard grass hay were investigated. Three Dorset x Suffolk ruminally fistulated lambs $(58.33 \pm 3.5 \mathrm{~kg})$ were assigned to one of three treatments in a 3 x 3 Latin Square design. Experimental periods (15 to $17 \mathrm{~d}$ ), included a 10 to $12-\mathrm{d}$ diet adaptation period and a 5-d sampling period. Lambs were fed at 0600 for all treatments and supplemented at 0600 (AM), 1800 (PM), or one half of daily allotment at both times (AP). There were treatment by time interaction effects on rumen concentrations of VFA, rumen $\mathrm{NH}_{3}-\mathrm{N}$ concentration and $\mathrm{pH}(\mathrm{P}<0.01)$. Liquid passage rates were similar amongst treatments $(\mathrm{PM}=8.69, \mathrm{AP}=8.48$, and $\mathrm{AM}=7.60 \pm 0.65 \% / \mathrm{h} ; \mathrm{P}=0.56) . \mathrm{PM}$ lambs had a slower solids passage rate $(\mathrm{P}=0.04)$ than the AM and AP groups $(8.13,9.83$ and $9.70 \pm 0.24 \% / \mathrm{h})$. Treatment did not affect hay intake, urine production, urine $\mathrm{NH}_{3}-\mathrm{N}$, nitrogen retention, or nutrient digestibility. Therefore, time of supplementation affected rumen kinetics and digestion but not total tract digestibility.

Key words: fats, lambs, rumen metabolism, supplement, time

\subsection{INTRODUCTION}

Feeding management strategies employed to improve ruminant food products fatty acid composition include feeding high concentrate diets (Kucuk et al., 2001), utilizing ruminal escape fats (Scollan et al., 2003; Lee et al., 2004), oilseed inclusion (Rule and Beitz; 1986, Chang et al., 
1992; Felton and Kerley., 2004), and free plant oils (Lough et al., 1992; Solomon et al., 1992;

Kucuk et al., 2004). The successfulness of these feeding strategies might be affected by diurnal rumen activity. Diurnal changes in grazing activity of ruminants in response to environmental temperatures, demand for other activities such as rumination and resting (Rook et al., 1994) and diurnal changes in nutrient composition of pasture (Orr et al., 1997) and rumen metabolites (Van Vuuren et al., 1986) can affect diurnal changes in rumen activity.

Feeding supplements also impact diurnal variation in rumen activity and hence, the time of supplementation has been viewed as critical to success of supplementation strategies. The importance of time of supplementation as an aspect of feeding management has been investigated for energy (Adams, 1985) protein (Barton et al., 1992; Robinson et al., 1997; and Gekara et al., 2005) and amino acid (Wiley et al., 1991; and McCracken et al., 1993) supplements. The results of these studies generally suggest that the time at which supplement is ingested could impact diurnal variation of rumen activity (presumably including ruminal biohydrogenation of ingested fatty acids), as well as total tract nutrient digestion. Furthermore, these studies have indicated the possibility for improving the efficiency of digestion and metabolism of specific nutrients while not adversely affecting digestion of other nutrients. Hence, we hypothesize that the time at which a fat enriched protein supplement is fed will affect diurnal rumen activity and total tract nutrient digestion of lambs fed poor quality forage. 


\subsection{MATERIALS AND METHODS}

\subsection{Animals and Diet}

Three Dorset x Suffolk ruminally fistulated wether lambs (initial BW $=58.33 \pm 3.5 \mathrm{~kg}$ ) were assigned to 1 of 3 treatments (AM, AP, PM) in an experiment utilizing a $3 \times 3$ Latin Square design. Ruminal cannulations were performed approximately 2 months prior to the initiation of the experiment. A rubber cannula (Bar Diamond Inc. Purma, ID) with an accompanying stopper seal was inserted into a $4 \mathrm{~cm}$ diameter ruminal fistula created in each wether's paralumbar fossa. All surgical and animal care procedures were approved by the University Animal Care and Use Committee (ACUC \# 050206). Treatments were times at which a soybean oil (3\% DMI) enriched protein supplement (22\% DMI) was offered relative to the time at which a low protein forage (Table 1) was introduced. The basal diet consisted of finely chopped orchard grass hay $(6.25 \mathrm{~cm} ; 6.4 \% \mathrm{CP})$ and was limit-fed at $95 \%$ ad lib (DM basis) intake in one allotment at 0600 for all treatment groups. Ad lib hay consumption was determined to be average daily hay intake of each wether for the final $5 \mathrm{~d}$ of a $12 \mathrm{~d}$ ad lib feeding period commencing $45 \mathrm{~d}$ post surgery. During the ad lib period wethers were housed in stainless steel metabolism crates in an environmentally controlled building and fed experimental hay once daily $(0600 \mathrm{~h})$ at $2.75 \%$ of their bodyweight. Each wether received $0.142 \mathrm{~g}$ of a trace mineral mix incorporated into the supplement on a daily basis. Supplement was offered at $0600 \mathrm{~h}$ (AM), or at $1800 \mathrm{~h}$ (PM), or at one half of daily allotment at both times (AP). Diets were formulated to be isonitrogenous, isocaloric (on a DM basis) and to meet the CP requirements of 60-kg lambs (NRC, 1985). The experimental periods (15 to $17 \mathrm{~d}$ ), included a 10 to 12 -d diet adaptation period followed by a 5 -d 
sampling period during which wethers were kept in individual stainless steel metabolism crates in the environmentally controlled building.

\subsection{Sample Collection and Analysis}

Bihourly samples

Beginning at $0600 \mathrm{~h}$ (AM AP \& PM) on d 1 of sampling, ruminal contents were collected from each wether ( 0 -h sampling time) via the rumen cannula. Ruminal samples were strained through four layers of cheesecloth, and $90 \mathrm{~mL}$ of the strained ruminal fluid was acidified with 1 $\mathrm{mL}$ of $1 \mathrm{~N} \mathrm{H}_{2} \mathrm{SO}_{4}$ and stored frozen $\left(-5^{\circ} \mathrm{C}\right)$ for later VFA and ammonia nitrogen $\left(\mathrm{NH}_{3}-\mathrm{N}\right)$ analysis. An additional $45 \mathrm{ml}$ of rumen fluid was collected, not acidified and stored at $\left(-5^{\circ} \mathrm{C}\right)$ to be used for $\mathrm{pH}$ measurements. Additional rumen samples were then collected throughout the sampling period at scheduled times relative to the time at which hay was introduced each day (0600 or 0 h sampling) on d 1; (6, 12, 18 h), d 2; (2, 8, 14, 20 h), d 3; (4, 10, 16, 22, 24 h), d 4; $(6,12,18 \mathrm{~h})$ and $\mathrm{d} 5 ;(24 \mathrm{~h})$. Collection times were therefore representative of at least 1 sample for every $2 \mathrm{~h}$ interval in a theoretical 24-h period post basal diet feeding. Rumen fluid VFA concentrations (Supelco, 1975), $\mathrm{NH}_{3}-\mathrm{N}$ concentrations (AOAC, 1990) and $\mathrm{pH}$ were then determined for 12 bihourly periods per treatment group.

\section{Passage rate samples}

Immediately after the 0 -h sampling of ruminal contents, $50 \mathrm{~g}$ of finely chopped $(6.25 \mathrm{~cm})$ $\mathrm{Yb}$-labeled orchard grass hay and $50 \mathrm{~mL}$ of Co EDTA were dosed into the rumen of each wether for estimation of solid (Varga and Prigge, 1982) and liquid digesta passage rates (Uden et. al., 1980), respectively. In the AP wethers, $25 \mathrm{~g}$ of Yb-labeled orchard grass hay and $25 \mathrm{~mL}$ of Co 
EDTA were dosed into the rumen at 0600 and again at 1800. Ruminal samples were then collected at $2,3,6,12,18,24,36$ and $48 \mathrm{~h}$ after the initial $0 \mathrm{~h}$ sample of $\mathrm{d} 1$. In the AP lambs the 12 hour rumen sample was collected prior to administering the second dose of $\mathrm{Yb}$ hay and Co EDTA. The rumen samples collected from the $12 \mathrm{~h}$ to $48 \mathrm{~h}$ in AP lambs were used for determination of passage rate. Ruminal samples were strained through four layers of cheesecloth and $30 \mathrm{~mL}$ of strained ruminal fluid was collected for determination of Co EDTA concentrations. After extraction of rumen fluid the remaining solid fraction of each sample was placed into $1 \mathrm{~L}$ plastic jugs and stored at $\left(-5^{\circ} \mathrm{C}\right)$ until they were analyzed for $\mathrm{Yb}$ concentrations. Solid digesta samples were dried in a forced-air oven at $65^{\circ} \mathrm{C}$, ground in a Wiley Mill (Thomas Scientific, Swedesboro, NJ) through a $1 \mathrm{~mm}$ screen, and then stored in sealed plastic bags. Solid samples were then dissolved in diethylenetriaminepentaacetic acid (Karimi et al., 1986), filtered through No. 41 Whatman filter paper, and the filtrate was stored in screw-cap plastic tubes at $4^{\circ} \mathrm{C}$ until analyzed. The latter solution and the rumen fluid samples were analyzed by atomic absorption spectroscopy to determine $\mathrm{Yb}$ (A Analyst 100, Perkin-Elmer, Norwalk, CT) and cobalt (Optima 2100 DV, Perkin-Elmer, Norwalk, CT) concentrations. The slope of the regression line obtained from a plot of the natural logarithm of $\mathrm{Yb}$ and cobalt concentrations versus time of sampling were used to determine passage rate.

Fecal grab samples were obtained at 12, 18, 24, 36, 48, 72 and $96 \mathrm{~h}$ after the initial $0 \mathrm{~h}$ (AM and AP: 0600 or PM: 1800) sample of d1 from the rectum of each lamb and stored at (-5 ${ }^{\circ} \mathrm{C}$ ) until they were analyzed for $\mathrm{Yb}$ concentrations. Fecal samples were processed and analyzed for $\mathrm{Yb}$ concentrations by the same procedure as described for rumen solid digesta samples to determine fecal passage rate. 


\section{Daily samples}

Total daily fecal and urine production during the $5 \mathrm{~d}$ sampling period were measured. Feces were collected in vessels located at the posterior- ventral end of the metabolism crates. Urine was collected in 3.7 liter plastic vessels which contained $10 \mathrm{ml}$ of $1 \mathrm{~N} \mathrm{H}_{2} \mathrm{SO}_{4}$. The urine collection vessels were located in a mid-ventral position of the metabolism crate. Average hay intake and fecal, and urine production were determined from daily measurements taken during the 5-d sampling period. Orts were collected and weighed daily to determine daily hay intake. Throughout the experimental period the daily allotted supplement was always consumed. At the start of each day, hay (200 g), soybean meal (20g), and at the end of each day fecal (200 g) were collected throughout the sampling period and frozen $\left(-5^{\circ} \mathrm{C}\right)$ until they were analyzed. Chemical analysis of hay, soybean meal, and fecal samples were used to determine nutrient digestibility. Urine collected from each lamb over the 5 days of sampling within each period was composited. An equal volume $(45 \mathrm{ml})$ of urine from each composite was used to determine Kjeldahl nitrogen (AOAC, 1990). Composite samples were also formed from the $5 \mathrm{~d}$ samples in each period for hay, and soybean meal. Composite samples were dried ground in a Wiley Mill (Thomas Scientific, Swedesboro, NJ) through a $1 \mathrm{~mm}$ screen, and stored in plastic bags. Sub-samples of the composite samples were analyzed in duplicate for DM, OM, ash, CP, NDF, ADF, ADL, CP and EE and average values are reported. Dry matter was determined from the differences in hay, soybean meal, and fecal sample weights pre and post drying (AOAC, 1990).Organic matter was determined following combustion of samples for $8 \mathrm{~h}$ at $550^{\circ} \mathrm{C}$ (AOAC, 1990). Crude protein content was determined by use the Kjeldahl method (AOAC, 1990). Concentrations of ash-free NDF, ADF, and ADL were determined using an Ankom 200 fiber analyzer (Ankom Technology Corp., Fairport, NY). Ether extract was determined following extraction of a 1-g sample with 
diethyl ether for $18 \mathrm{~h}(\mathrm{AOAC}, 1990)$. Percentage nitrogen retention $(\% \mathrm{~N})$ was determined from the following formula;

$\% \mathrm{~N}$ retention $=[($ Nitrogen intake in hay and supplement $)-($ Nitrogen output in feces and urine $)$ / (Nitrogen intake in hay and supplement)] X 100.

\subsection{DATA ANALYSIS}

Hay intake, fecal and urine production, urinary $\mathrm{N}$, nutrient digestibility, percentage nitrogen retention, and passage rate data were analyzed as a 3 x 3 Latin Square arrangement of treatments (AM, AP, PM with 3 replicates per treatment) using the GLM procedures of SAS (SAS, Institute, Cary, NC). Lambs, experimental period, and treatment were main effects. Statistical analysis of ruminal $\mathrm{VFA}, \mathrm{NH}_{3}-\mathrm{N}$ concentrations and $\mathrm{pH}$ were done using a repeated measures covariance model with treatment, lambs, experimental period, and time (after hay was fed) as main factors.

\subsection{RESULTS AND DISCUSSION}

Treatment affected $(\mathrm{P}=0.04)$ rumen kinetics (Table 2). However, hay intake, fecal production, urine production, urinary $\mathrm{N}$, nitrogen retention, or any of the measured digestibility variables were not affected $(\mathrm{P}>0.05)$ by treatment $($ Table 3$)$.

\subsection{Rumen Variables}

There was a significant $(\mathrm{P}<0.001)$ treatment by time interaction on rumen concentrations of total and individual VFA, rumen $\mathrm{NH}_{3}-\mathrm{N}$ and $\mathrm{pH}$ (Figs. 1 to 9). Demonstrating protein fermentation, the patterns of changes in concentrations of rumen volatile fatty isoacids 
(Figs. 4 to 6; isobutyrate, isovalerate, and valerate) corresponded to the patterns observed for rumen $\mathrm{NH}_{3}-\mathrm{N}$ concentration for each treatment group. Furthermore, the relationship between time of supplementation and ruminal digestion of the soybean meal is also reflected in the rumen concentration profiles for valerate, isobutyrate and isovalerate (Figs. 4 to 6). Valerate, isobutyrate and isovalerate arise from the metabolism of branched-chain amino acids (Maeng and Baldwin, 1976; Argyle and Baldwin, 1989). Consequently, as observed in this study, the bihourly fluctuations in ruminal concentrations of these isoacids paralleled the changes in ruminal $\mathrm{NH}_{3}-\mathrm{N}$ reflecting treatment induced differences in ruminal degradation of soybean meal branched-chain amino acids.

The rumen $\mathrm{NH}_{3}-\mathrm{N}$ concentration profiles observed in this study are the result of the effects of individual supplementation strategy upon post-prandial variation of ruminal activity. Soybean meal contributed approximately $50 \%$ of the lambs' daily CP requirement. The other 50 $\%$ of the daily $\mathrm{CP}$ requirement would be obtained from the orchard grass hay that was fed to these lambs. Therefore, lambs received approximately $50 \%$ (PM), 75 and $25 \%$ (AP), or $100 \%$ (AM) of their daily $\mathrm{CP}$ requirement at the time(s) of supplementation. Hence, the effects of altering the time at which protein was supplemented would have most likely impacted microbial population dynamics and activity throughout the day creating the observed transient changes in ruminal digestion in each treatment. Lambs that were supplemented in the morning showed an $\mathrm{NH}_{3}-\mathrm{N}$ concentration profile that would indicate a steady degradation of both forage and supplemental protein throughout the day. Lambs that were supplemented in both the morning and evening (AP) similarly showed $\mathrm{NH}_{3}-\mathrm{N}$ profile that reflected protein degradation. Dividing the daily supplement created a relatively earlier decline in $\mathrm{NH}_{3}-\mathrm{N}$ concentration than observed with the AM lambs. This would be expected because of the relatively lower quantity of protein 
that was accessed by the AP lambs in the first $12 \mathrm{~h}$ post feeding of hay. The digestion of the second dose of soybean meal, ingested hay and possibly recycled nitrogen created the observed resurgence of $\mathrm{NH}_{3}-\mathrm{N}$ during the second part of the day in AP supplemented lambs. Delaying supplementation until $12 \mathrm{~h}$ post feeding of hay (PM) separated daily protein digestion into two distinct periods which created a third distinct $\mathrm{NH}_{3}-\mathrm{N}$ concentration profile. Protein supplementation has been reported to increase ruminal $\mathrm{NH}_{3}-\mathrm{N}$ concentration at a time when adequate $\mathrm{NH}_{3}-\mathrm{N}$ concentrations already exist from degradation of forage protein in ruminants (Judkins et al., 1991; Barton et al., 1992; Gekara et al. 2001). Similarly in this study, the peak in $\mathrm{NH}_{3}-\mathrm{N}$ concentrations observed with PM supplemented lambs might be attributable to a protein supplement induced increase in ruminal $\mathrm{NH}_{3}-\mathrm{N}$ compounded with forage originated ruminal $\mathrm{NH}_{3}-\mathrm{N}$.

Digestion of the dietary protein might have been further affected by ruminal passage rate of solid digesta. Passage rate of rumen solid digesta was slower for the PM lambs than for the AM or AP lambs ( $\mathrm{P}<0.04$; Table 2). A slower solid digesta passage rate for the PM lambs would have permitted greater time for ruminal digestion and most likely explains the rumen $\mathrm{NH}_{3}-\mathrm{N}$ profile observed in PM lambs. In a similar fashion, a presumably slower passage rate of soybean meal supplied in the evening to AP lambs would lead to enhanced digestion of protein. Interestingly, while not statistically different $(\mathrm{P}=0.47)$ there was a numerical difference in average daily urinary $\mathrm{N}$ production $(4.29,7.83$ and $5.83 \pm 2.54 \mathrm{mg} / \mathrm{dl})$ for $\mathrm{AM}$, AP, and PM groups respectively (Table 3 ). This suggested that increased protein degradation resulted in greater nitrogen loss via the urine. Additionally, total tract crude protein digestibility did not differ across treatment groups $(\mathrm{P}=0.99$; Table 3$)$. Net nitrogen retention, did not differ $(\mathrm{P}=$ 
0.44), and might have been sufficient to suffice lambs daily requirements in all treatment groups. Excess nitrogen was simply excreted in the urine.

Elevated ruminal $\mathrm{NH}_{3}-\mathrm{N}$ concentrations $(\geq 29 \mathrm{mg} / \mathrm{dl})$ might provide bacteria with an optimal environment for forage digestion (Owen and Zinn, 1988) or simply increase the potential for increased nitrogen loss (Beever and Siddons, 1986). When $\mathrm{NH}_{3}-\mathrm{N}$ concentrations are high, increased gradients and diffusion arise, and $\mathrm{NH}_{3}-\mathrm{N}$ can more effectively permeate all niches of the rumen (Owen and Zinn, 1988). The latter suggests that timing of daily protein supplementation might affect ruminal microbial digestion of fiber by providing a more stable $\mathrm{NH}_{3}-\mathrm{N}$ concentration or by synchronizing nutrient availability during microbial digestion (Judkins et al., 1991). However, no benefit of such synchronization was seen in vivo with continuous infusion of urea (Mizwicki et al., 1980).

Intake, digestion, or digesta kinetics of low quality forage was unaltered by time of protein supplementation in earlier reported studies (Judkins et al., 1991; Barton et al., 1992). Conversely, an influence of time of supplementation in relation to time of basal diet intake on forage DM and NDF disappearance was observed $(\mathrm{P}<0.05)$ in methionine supplemented steers (Wiley et al., 1991). Amongst steers grazing early-spring fescue pasture, those supplemented in the morning had increased rate of NDF digestion but indifferent forage intake or passage rate of digesta $(\mathrm{P}>0.05)$ in comparison to those supplemented in the afternoon or not supplemented. Notably, AM steers had numerically greater forage intake, particulate passage rate, and shorter retention times, a pattern which was similar to what was observed for AM treated wethers in this current study, despite the lack of major differences $(\mathrm{P}>0.05)$ in intake and digestibility as was previously reported. 


\subsection{Rumen Volatile Fatty Acids}

For each treatment group, a distinct pattern of acetate, propionate, butyrate and consequently TVFA concentration profiles were also discernable (Figs. 1, 2, 3 and 7). The patterns of acetate, propionate, butyrate and consequently TVFA concentration were similar to those for rumen $\mathrm{NH}_{3}-\mathrm{N}$ concentrations and were also determined by the supplementation strategy. In a similar study Kucuk et al. (2004) fed increasing amounts of dietary soybean oil supplement to lambs that were fed a high concentrate diet. They offered a split dose of the soybean oil supplement at the time of feeding a basal diet (0630 and 1830). Two supplementation times per treatment group per day were used compared to a one time supplementation as in the current study. Effectively what they did was supplement twice daily using approximately 1.6,3.3 and $4.7 \%$ soybean oil at each supplementation time, which results in their reported daily supplement values of $3.2,6.3$, and $9.4 \%$ soybean oil. Similar to the current study, these researchers observed changes in magnitude of volatile fatty acid production over time within treatment with all levels of soybean oil supplementation. In addition, these researchers observed an interaction between ruminal sampling hour and diet for ruminal acetate ( $\mathrm{P}<0.001)$, propionate $(\mathrm{P}=0.05)$, and acetate: propionate ratio $(\mathrm{P}<0.001)$ which was similar to the interaction observed between ruminal sampling hour and time of supplementation for TVFA concentrations $(\mathrm{P}<0.001)$ in this study. However, despite differences in rumen fermentation characteristics, overall organic matter digestibility was reportedly unaffected by level of dietary soybean oil ( $\mathrm{P}=0.93$; Kucuk et al., 2004), or time at which oil supplement was given ( $\mathrm{P}=0.78$; Table 2) as was observed in our study. 
Rumen digestion is a time related process and production of ruminal end products are largely affected by the reactants and reaction conditions within the rumen which in turn are subject to continuously modifying but homeostatic buffering activities of the rumen. Altering the reactant composition and conditions by introducing soybean oil in combination with dietary protein at different times or different dietary levels should change VFA production over the time course of the fermentation process. Changes in VFA production over time reflect enhanced or inhibited fiber digestion via altered microbial activity. Hence, transient changes in VFA production were affected by feeding $3.2 \%$ dietary soybean oil to concentrate fed lambs (Kucuk et al., 2004) and by possibly altering the time at which a similar $3 \%$ (DM) dietary soybean oil supplement was fed to forage fed lambs in this study.

\subsection{Rumen $\mathrm{pH}$}

The fluctuations in both VFA and rumen $\mathrm{NH}_{3}-\mathrm{N}$ concentrations with time after hay was fed across all the treatment groups $(\mathrm{P}<0.001)$ were reflected in rumen $\mathrm{pH}$ changes (Fig. 9). As total VFA increased, the rumen $\mathrm{pH}$ decreased and as rumen ammonia concentrations were elevated rumen $\mathrm{pH}$ increased. Feeding strategies influence diurnal $\mathrm{pH}$ variation, average daily ruminal $\mathrm{pH}$ and digestibility of OM, NDF and ADF (Wales et al., 2004). The bihourly fluctuations in ruminal $\mathrm{pH}, \mathrm{VFA}$, and $\mathrm{NH}_{3}-\mathrm{N}$ across different treatment groups observed in this study exemplifies such influences. Variation in ruminal $\mathrm{pH}$ can be explained in part by the diurnal grazing pattern of ruminants, periodicity of dry matter intake and subsequent rumination (Wales and Doyle, 2003). Although the current study did not determine diurnal feeding pattern or periodicity of dry matter intake, it is plausible that the observed variations in $\mathrm{pH}$ were reflective of feeding pattern or periodicity of dry matter intake. Diurnal variations in fermentation product 
concentrations were measured and did relate closely to diurnal changes in $\mathrm{pH}$ across all treatment groups. Indeed, ruminal $\mathrm{pH}$ is the net effect of rates of production and absorption of acidic fermentation products and the addition of buffers to the rumen via saliva (Wales et al., 2004).

The observed effects of supplementation strategy on bihourly $\mathrm{pH}$ also suggest possible effects of treatments on ruminal biohydrogenation of ingested fatty acids. Factors altering ruminal fermentation and the microbial population also regulate the rate and extent of ruminal biohydrogenation of unsaturated fatty acids (Kucuk et al., 2001; Qiu et al., 2004). Reduced ruminal $\mathrm{pH}$ adversely affected microbial populations, especially cellulolytic bacteria, and reduced ruminal biohydrogenation (Harfoot and Hazelwood, 1997; Kucuk et al., 2001; Qiu et al., 2004).The supplementation strategies used in this study affected diurnal variation of $\mathrm{pH}$, VFA and $\mathrm{NH}_{3}-\mathrm{N}$ concentrations and hence, it is possible that microbial population and ruminal biohydrogenation of unsaturated fatty acids were also affected.

\subsection{Passage rates and Digestibility}

Differences $(\mathrm{P}=0.56)$ were not observed for passage rate of rumen liquid digesta across treatments. However, there were differences $(\mathrm{P}=0.04)$ in solids digesta passage rate as affected by treatments. The PM treated group had a slower solids passage rate $(8.13 \% / \mathrm{h})$ than the AM $(9.83 \% / \mathrm{h})$ and AP $(9.70 \% / \mathrm{h})$ groups $(\mathrm{P}=0.04)$. Solid passage rate did not differ between the $\mathrm{AM}$ and $\mathrm{AP}$ groups $(\mathrm{P}>0.05)$. Although not significant, numerically higher liquid passage rates were observed in the PM $(8.69 \% / \mathrm{h})$ and AP $(8.48 \% / \mathrm{h})$ compared to the AM $(7.60 \% / \mathrm{h})$ treated lambs (Table 2). The numerically higher liquid passage rate observed in the PM and AP treated lambs suggests a possible faster soybean oil out flow from the rumen. Kucuk et al. (2004) observed a cubic response $(\mathrm{P}=0.02)$ for fluid passage rate when dietary soybean oil was 
increased from 0 to 3.2 , to $6.3 \%$, and then to $9.4 \%$ of dietary DM. It is postulated that these effects might be mediated through interaction with diurnal ruminal activity, postrumen digesta flow as well as whole body homeostatic activity.

Numerical but non-significant differences in fecal passage rate were observed across treatment groups $(\mathrm{P}=0.40$; Table 2). Fecal passage rate was slowest in AM $(2.00 \% / \mathrm{h})$ supplemented lambs as compared to PM $(3.58 \% / \mathrm{h})$ and AP $(2.69 \% / \mathrm{h})$ lambs, which suggest that ingested materials may have had a longer post-rumen digestive period in the AM lambs than in the other two treatments. An increased time spent in the lower digestive tract would favor increased digestion of digesta beyond the rumen. An increase in time in the post-rumen digestive tract would seem necessary, because of lower ruminal digestion associated with shorter ruminal retention for AM treated lambs relative to PM and AP lambs. Additionally, total tract digestibility did not vary across treatment groups $(\mathrm{P}>0.05$; Table 3$)$ suggesting that postruminal digestion might have compensated for lower rumen digestion in the AM treated lambs.

Theoretically, through rumen buffering activities, the recycling of nitrogen via the saliva, changes in microbial population dynamics, and most likely the passage of rumen digesta, rumen digestibility was controlled to maintain a homeostatic rumen environment. Therefore, as suggested by fluctuating bihourly rumen VFA, TVFA, $\mathrm{NH}_{3}-\mathrm{N}$ concentrations and $\mathrm{pH}$, digestive activity fluctuates throughout the day but within restricted limits. The experiment did not examine the composition of digesta leaving the rumen and so any differences in composition of exiting digesta across the treatment groups were not detectable. Importantly, differences in biohydrogenation of ingested fatty acids, modification of fatty acid intermediates, and microbial population dynamics over time might have occurred. 


\subsection{CONCLUSIONS}

The need for supplementing crude protein and the supplementation strategy utilized resulted in the effects of fat and protein supplementation being confounded. Nevertheless, rumen digestion seemed to be affected by time of supplementation. This relationship was evidenced by synchrony of rumen VFA and $\mathrm{NH}_{3}-\mathrm{N}$ concentrations at time intervals consistent with the time of supplementation used for each treatment. Differences in solid passage rate might have affected ruminal digestion. Post ruminal digestibility was probably compensatory and hence overall digestibility did not differ due to time of supplementation.

Therefore, the time of supplementation of a $3 \%$ (DM) soybean oil and $22 \%$ (DM) soybean meal supplement for lambs fed with poor quality hay created differences in rumen kinetics and rumen digestion but not total tract digestibility. Thus, the effectiveness of each fat supplementation strategy should be further investigated. 
Table 1. Nutrient composition of orchard grass hay and soybean meal

Feed

\begin{tabular}{l|ll}
\hline Nutrient (\%) & Hay & Soybean meal \\
\hline DM & 90.63 & 49.32 \\
OM & 93.92 & 93.63 \\
NDF & 55.56 & 4.66 \\
ADF & 33.03 & 1.68 \\
ADL & 4.58 & 0.00 \\
CP & 6.38 & 48.82 \\
Ash & 6.08 & 6.37 \\
Ether Extract & 2.72 & 1.19 \\
\hline
\end{tabular}

Table 2. Passage rates of ruminal contents and digesta kinetics of wethers supplemented with a soybean oil enriched protein supplement

Treatments $^{1}$

\begin{tabular}{l|llllc}
\hline Variable & AM & AP & PM & \pm SE & P-value \\
\cline { 2 - 6 } Liquid $(\% / \mathrm{h})$ & 7.60 & 8.48 & 8.69 & 0.65 & 0.56 \\
Solid $(\% / \mathrm{h})$ & $9.83^{\mathrm{a}}$ & $9.70^{\mathrm{a}}$ & $8.13^{\mathrm{b}}$ & 0.24 & 0.04 \\
Fecal $(\% / \mathrm{h})$ & 2.00 & 2.69 & 3.58 & 0.65 & 0.40 \\
\hline
\end{tabular}

${ }^{1}$ AM, PM, AP: Supplement fed at 0600, 1800, or half a dose at both times

${ }^{\mathrm{a}, \mathrm{b}}$ Within a row means without a common superscript letter differ $(\mathrm{P}<0.05)$ 
Table 3. Average daily hay and supplement intakes, nitrogen retention, fecal, urine and urinary $-\mathrm{N}$ production and total tract nutrient digestibility of wethers supplemented with a soybean oil enriched protein supplement

\begin{tabular}{|c|c|c|c|c|c|}
\hline \multicolumn{6}{|c|}{ Treatments $^{1}$} \\
\hline Variable & $\mathrm{AM}$ & $\mathrm{AP}$ & $\mathrm{PM}$ & $\pm \mathrm{SE}$ & $\mathrm{P}$ - value \\
\hline Hay $(g)$ & 906.11 & 860.40 & 914.96 & 25.33 & 0.43 \\
\hline Supplement (g) & 196.22 & 196.22 & 196.22 & 0.00 & 1.00 \\
\hline Feces $(\mathrm{g})$ & 295.00 & 278.58 & 305.62 & 15.01 & 0.55 \\
\hline Urine (ml) & 927.40 & 923.00 & 771.00 & 107.74 & 0.46 \\
\hline Urinary nitrogen $(\mathrm{mg} / \mathrm{dL})$ & 4.29 & 7.83 & 5.83 & 2.54 & 0.47 \\
\hline Nitrogen retention (\%) & 95.47 & 94.68 & 93.91 & 0.58 & 0.44 \\
\hline \multicolumn{6}{|l|}{$\underline{\text { Nutrient Digestibility }}$} \\
\hline $\operatorname{DM}(\%)$ & 73.70 & 74.20 & 72.95 & 0.88 & 0.66 \\
\hline $\mathrm{OM}(\%)$ & 73.38 & 73.72 & 72.86 & 0.82 & 0.78 \\
\hline $\mathrm{CP}(\%)$ & 94.82 & 94.76 & 94.78 & 0.36 & 0.99 \\
\hline NDF $(\%)$ & 64.74 & 67.10 & 64.70 & 1.37 & 0.49 \\
\hline $\operatorname{ADF}(\%)$ & 61.79 & 64.09 & 61.02 & 1.64 & 0.51 \\
\hline $\operatorname{ADL}(\%)$ & 19.93 & 23.94 & 17.62 & 4.56 & 0.67 \\
\hline Ether extract $(\%)$ & 89.29 & 91.50 & 90.12 & 0.59 & 0.22 \\
\hline
\end{tabular}




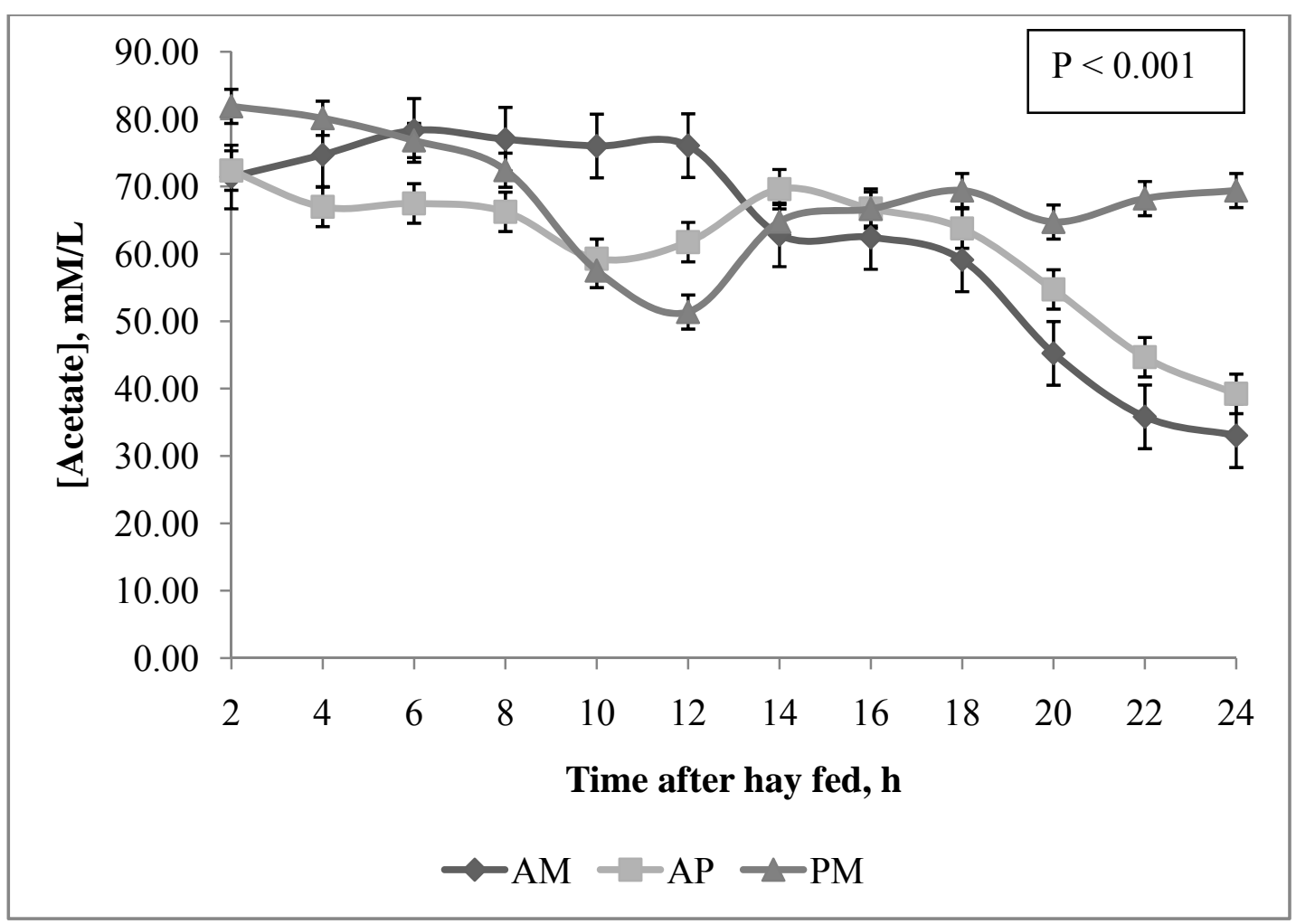

Figure 1. Effects of time of supplementation on rumen acetate concentrations in wethers supplemented with a soybean oil enriched protein supplement.

AM: Soybean oil and soybean meal supplement fed at 0600

AP: Soybean oil and soybean meal supplement fed in two half doses at 0600 and 1800

PM: Soybean oil and soybean meal supplement fed at 1800

Treatment by time interaction effect is significant if $\mathrm{P}<0.001$ 


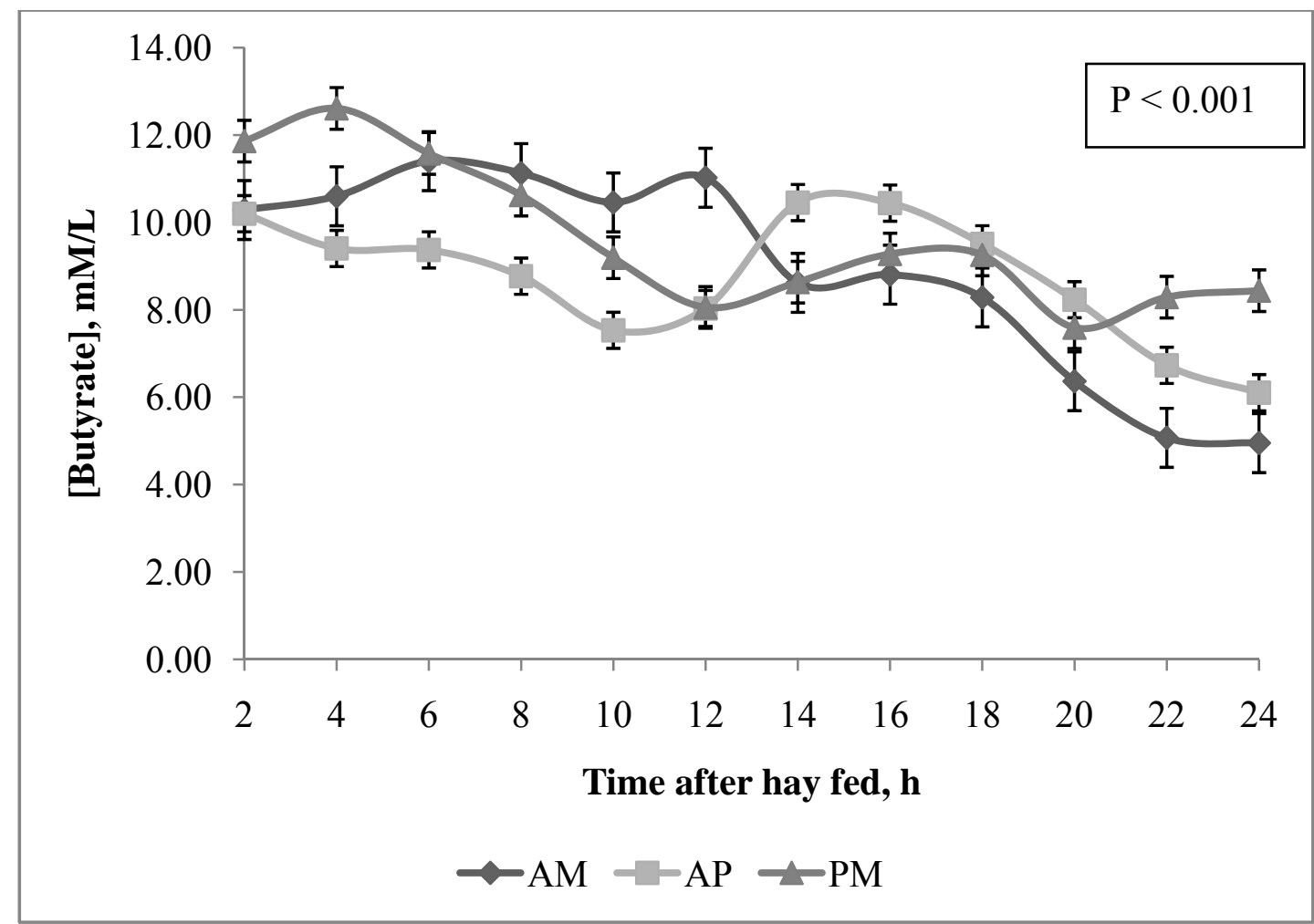

Figure 2. Effects of time of supplementation on rumen butyrate concentrations in wethers supplemented with a soybean oil enriched protein supplement.

AM: Soybean oil and soybean meal supplement fed at 0600

AP: Soybean oil and soybean meal supplement fed in two half doses at 0600 and 1800

PM: Soybean oil and soybean meal supplement fed at 1800

Treatment by time interaction effect is significant if $\mathrm{P}<0.001$ 


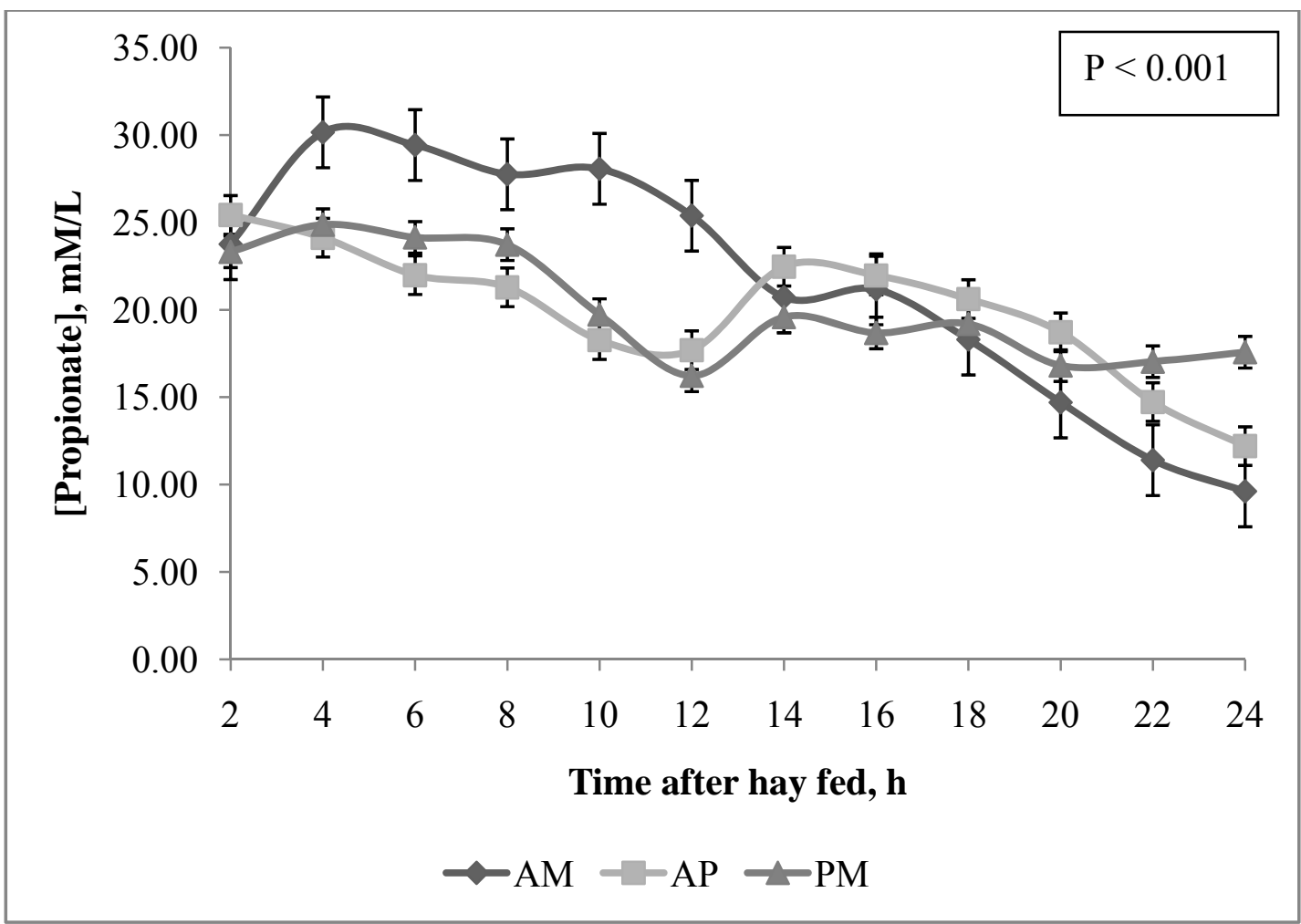

Figure 3. Effects of time of supplementation on rumen propionate concentrations in wethers supplemented with a soybean oil enriched protein supplement.

AM: Soybean oil and soybean meal supplement fed at 0600

AP: Soybean oil and soybean meal supplement fed in two half doses at 0600 and 1800

PM: Soybean oil and soybean meal supplement fed at 1800

Treatment by time interaction effect is significant if $\mathrm{P}<0.001$ 


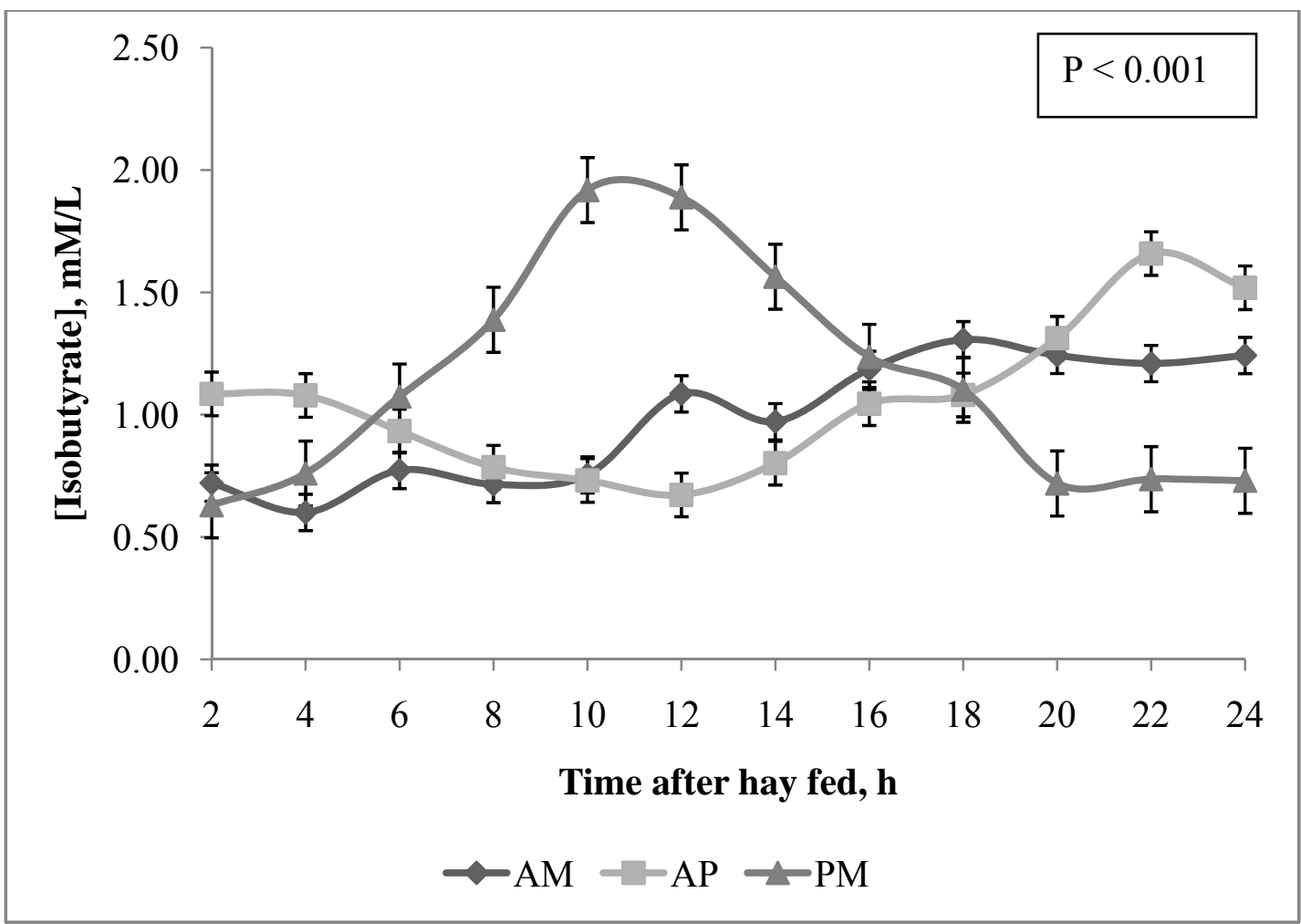

Figure 4. Effects of time of supplementation on rumen isobutyrate concentrations in wethers supplemented with a soybean oil enriched protein supplement.

AM: Soybean oil and soybean meal supplement fed at 0600

AP: Soybean oil and soybean meal supplement fed in two half doses at 0600 and 1800

PM: Soybean oil and soybean meal supplement fed at 1800

Treatment by time interaction effect is significant if $\mathrm{P}<0.001$ 


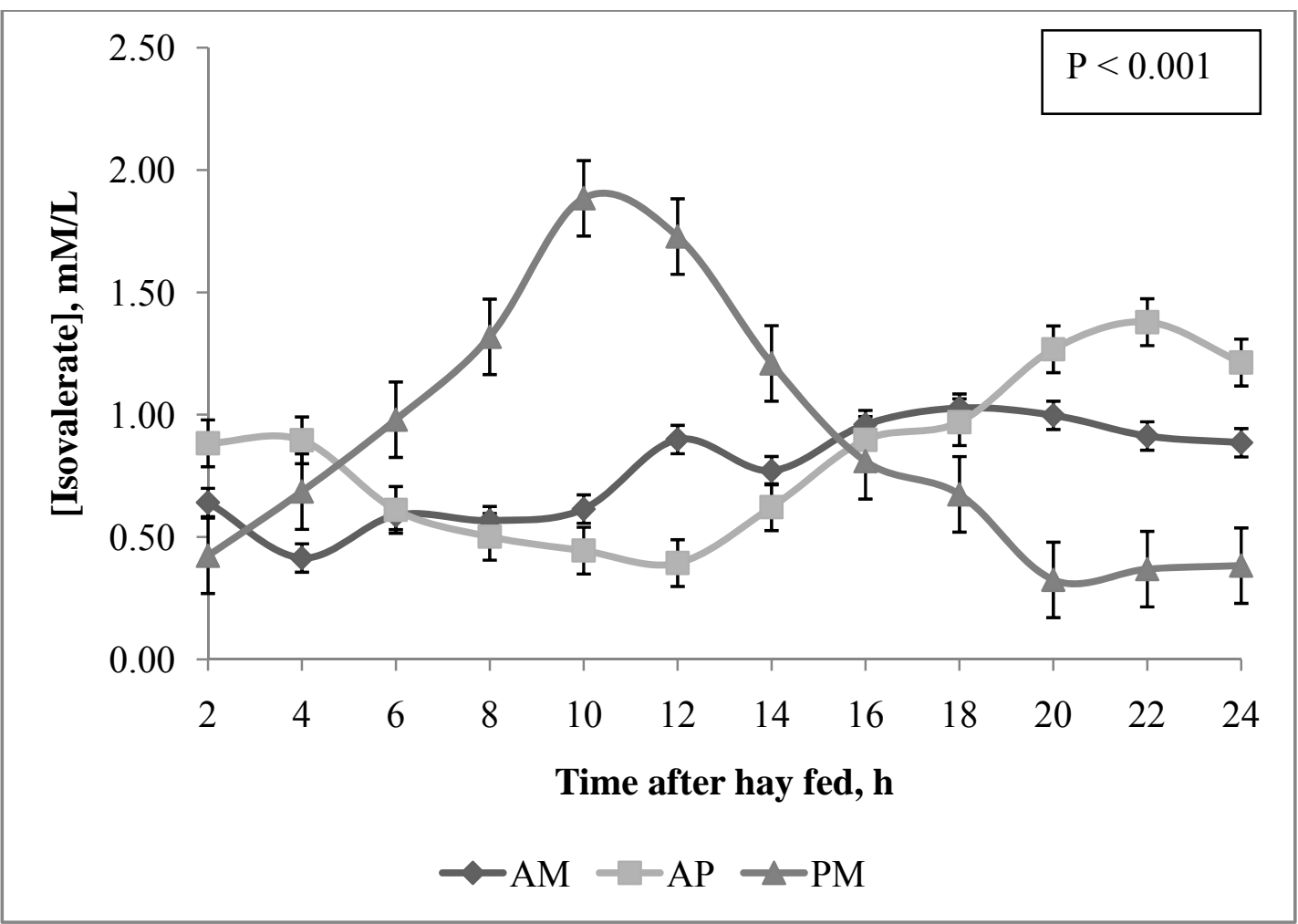

Figure 5. Effects of time of supplementation on rumen isovalerate concentrations in wethers supplemented with a soybean oil enriched protein supplement.

AM: Soybean oil and soybean meal supplement fed at 0600

AP: Soybean oil and soybean meal supplement fed in two half doses at 0600 and 1800

PM: Soybean oil and soybean meal supplement fed at 1800

Treatment by time interaction effect is significant if $\mathrm{P}<0.001$ 


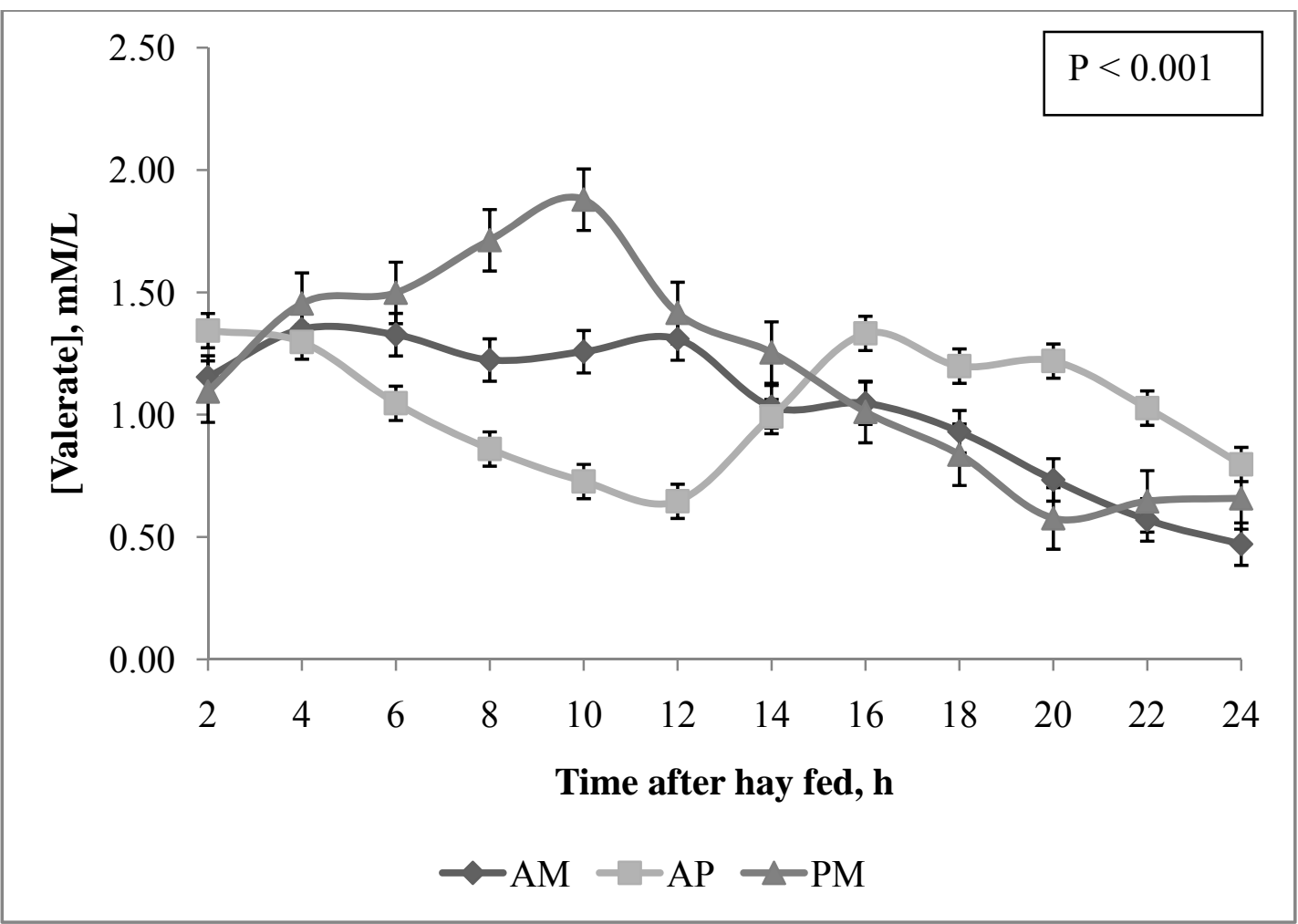

Figure 6. Effects of time of supplementation on rumen valerate concentrations in wethers supplemented with a soybean oil enriched protein supplement.

AM: Soybean oil and soybean meal supplement fed at 0600

AP: Soybean oil and soybean meal supplement fed in two half doses at 0600 and 1800

PM: Soybean oil and soybean meal supplement fed at 1800

Treatment by time interaction effect is significant if $\mathrm{P}<0.001$ 


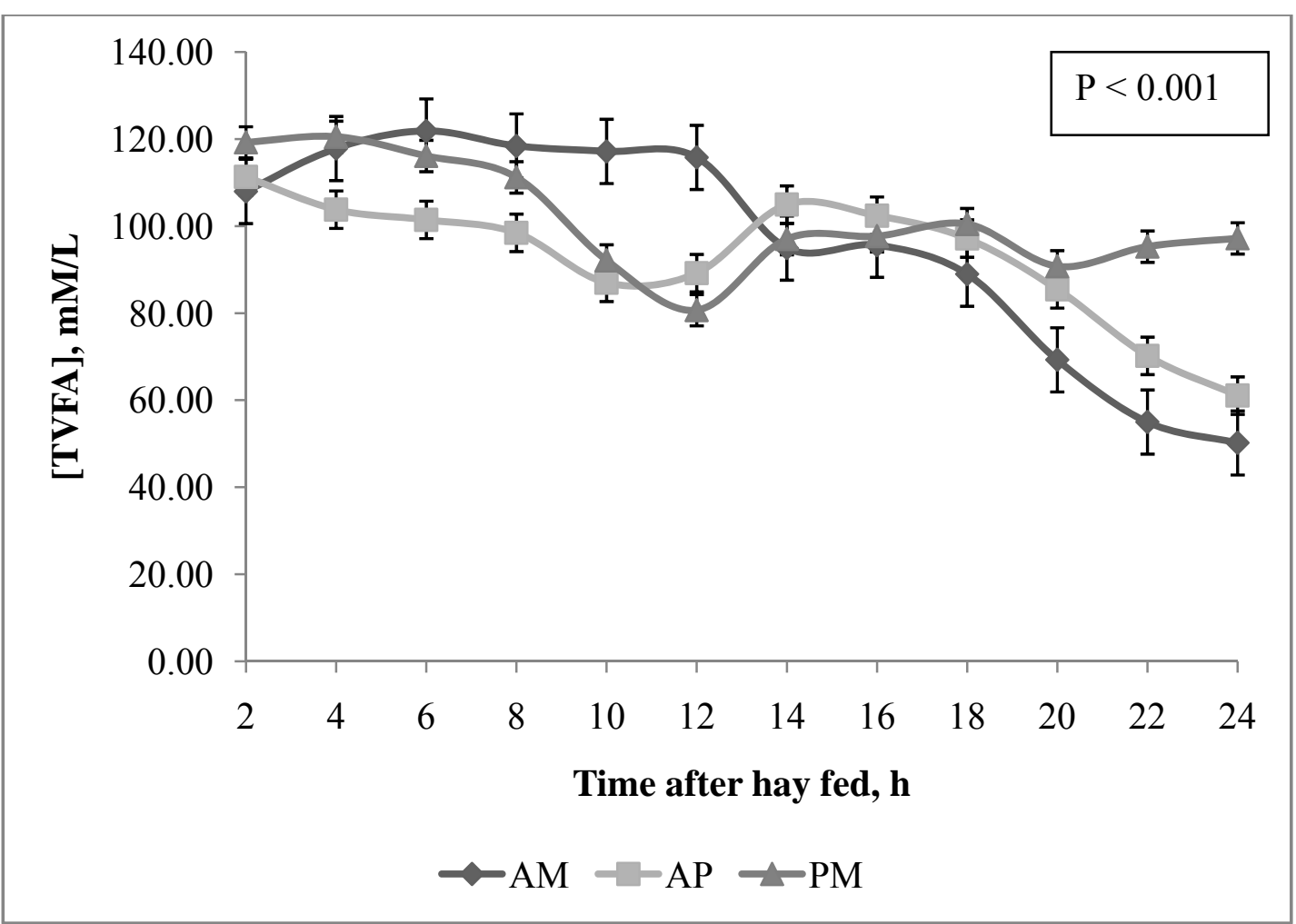

Figure 7. Effects of time of supplementation on TVFA ${ }^{1}$ concentrations in wethers supplemented with a soybean oil enriched protein supplement.

${ }^{1}$ Toal volatile fatty acid

AM: Soybean oil and soybean meal supplement fed at 0600

AP: Soybean oil and soybean meal supplement fed in two half doses at 0600 and 1800

PM: Soybean oil and soybean meal supplement fed at 1800

Treatment by time interaction effect is significant if $\mathrm{P}<0.001$ 


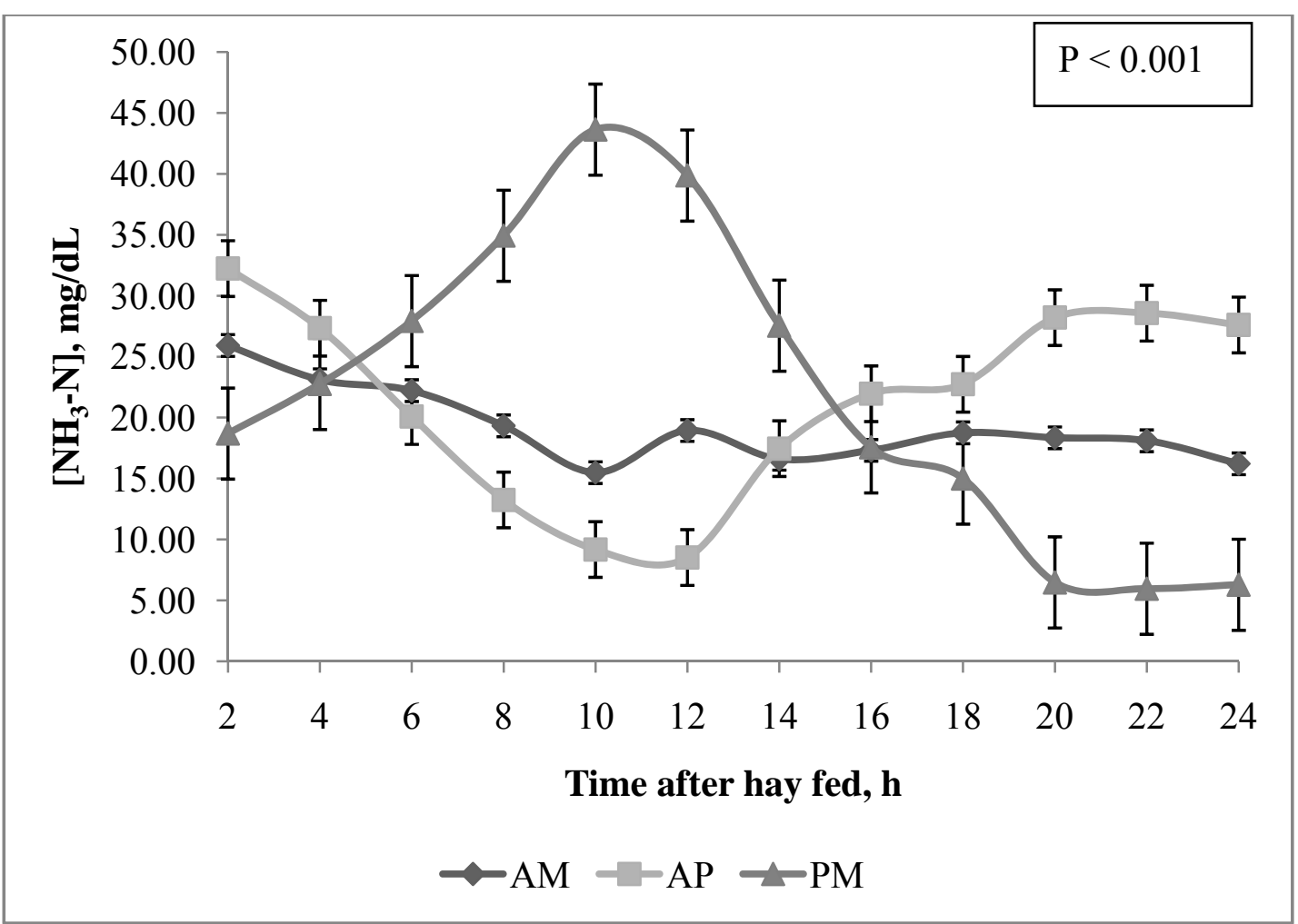

Figure 8. Effects of time of supplementation on rumen $\mathrm{NH}_{3}-\mathrm{N}^{1}$ concentrations in wethers supplemented with a soybean oil enriched protein supplement.

\footnotetext{
${ }^{1}$ Ammonia nitrogen
}

AM: Soybean oil and soybean meal supplement fed at 0600

AP: Soybean oil and soybean meal supplement fed in two half doses at 0600 and 1800

PM: Soybean oil and soybean meal supplement fed at 1800

Treatment by time interaction effect is significant if $\mathrm{P}<0.001$ 


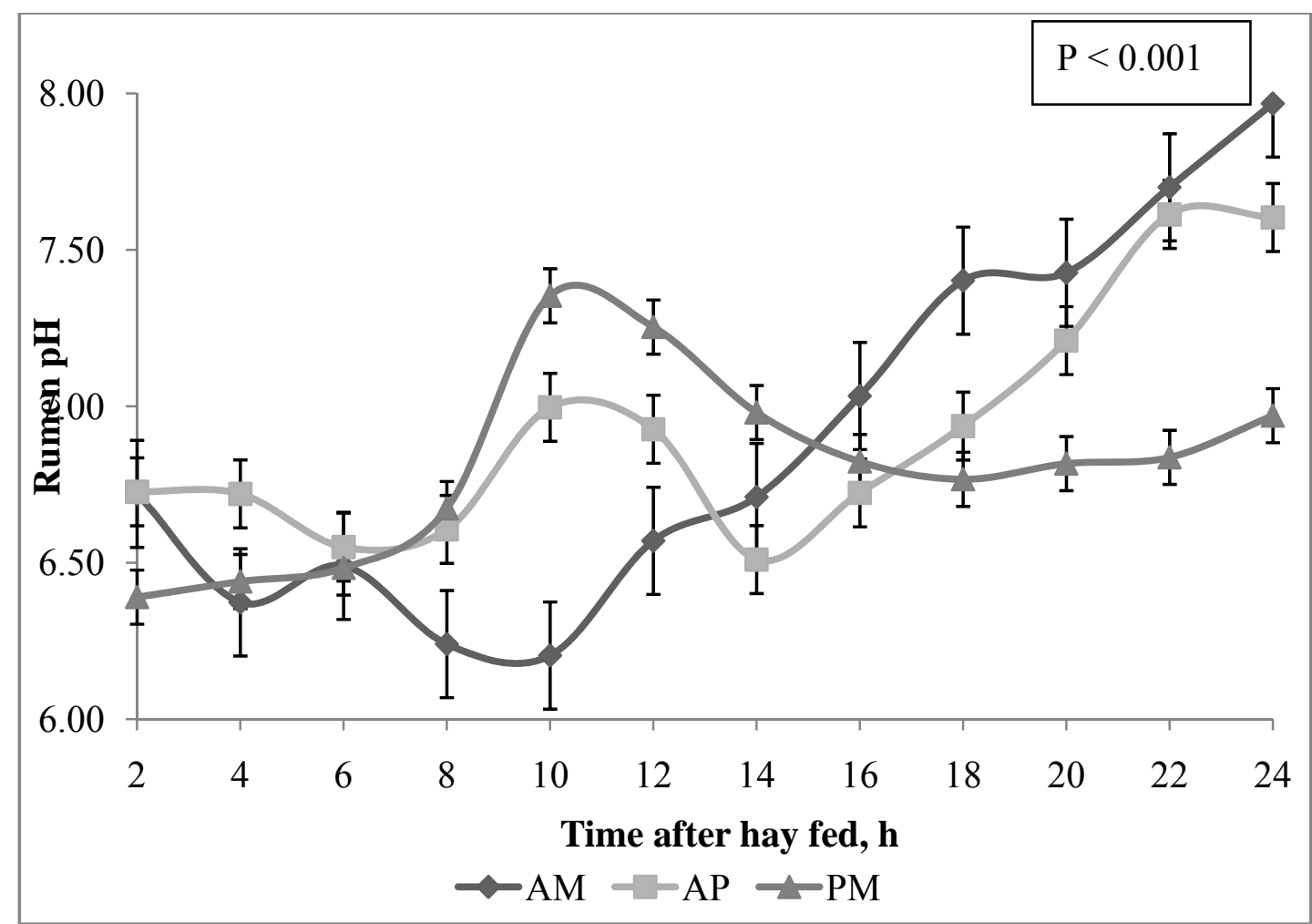

Figure 9. Effects of time of supplementation on rumen $\mathrm{pH}$ in wethers supplemented with a soybean oil enriched protein supplement.

AM: Soybean oil and soybean meal supplement fed at 0600

AP: Soybean oil and soybean meal supplement fed in two half doses at 0600 and 1800

PM: Soybean oil and soybean meal supplement fed at 1800

Treatment by time interaction effect is significant if $\mathrm{P}<0.001$ 


\section{Chapter 4 : EXPERIMENT 2}

Effects of a fat, protein or fat enriched protein supplement on performance and tissue fatty acid composition of grazed lambs.

\subsection{ABSTRACT}

The effects of fat (F), protein (PR), and fat enriched protein (FP) supplements on performance and tissue fatty acid composition of grazed lambs were investigated. Lambs (33) were blocked by sex and weight $(19.71 \pm 1.74 \mathrm{~kg})$ and randomly allocated to receive one of three supplements offered at 10 (F and PR), and 13\% (FP) of estimated daily dry matter intake. Supplements offered were a 1:1 ratio of soybean meal : soybean hull with either $0(\mathrm{PR}), 23 \%$ added soybean oil (FP) or soybean hulls carrying 30\% added soybean oil (F). All supplements were offered at $1600 \mathrm{~h}$ for the final $29 \mathrm{~d}$ of an 81-day stay on mixed pastures and then for an additional $39 \mathrm{~d}$ finishing period in drylot. During this latter period, lambs were fed orchard grass and alfalfa hay (1:1) along with the prescribed supplement. Herbage mass and accumulation rate and pasture quality and accessibility were similar across treatments. Descriptive data on the percentage of daily supplement and hay consumed $(\mathrm{F}=88.63, \mathrm{PR}=81.01, \mathrm{FP}=88.14 \pm 2.42 \%)$ and $(\mathrm{F}=81.92, \mathrm{PR}=85.10, \mathrm{FP}=82.14 \pm 0.79 \%)$ were reported. Grazing activity of each treatment flock prior to and after daily supplementation were also reported as descriptive data (F $=82.82, \mathrm{PR}=45.45, \mathrm{FP}=0.00 \pm 12.50 \%)$ and $(\mathrm{F}=36.36, \mathrm{PR}=0.00, \mathrm{FP}=0.00 \pm 8.78 \%)$.

Daily gains of lambs with supplementation while on pasture differed $(\mathrm{F}=0.30, \mathrm{PR}=0.22, \mathrm{FP}=$ $0.27 \pm 0.02 \mathrm{~kg} / \mathrm{d}, \mathrm{P}=0.05)$. During the first 2 weeks in the drylot, ADG differed amongst treatments $(\mathrm{F}=-0.05, \mathrm{PR}=0.23, \mathrm{FP}=0.11 \pm 0.05 \mathrm{~kg} / \mathrm{d}, \mathrm{P}<0.01)$. Overall, ADG of lambs, and HCW of slaughtered wether lambs were similar across treatments $(\mathrm{P}>0.05)$, but dressing 
percentage was numerically higher in PR than in F and FP wethers (46.62, 44.27 and $43.85 \pm$ $0.76 \%, \mathrm{P}=0.08$ ). The SFA: UFA of muscle was lower in the F than in FP and PR treatments (0.98 vs 1.38 and $1.22 \pm 0.07, \mathrm{P}=0.02$ ), and kidney PUFA: SFA was lowest in PR vs F and FP $(0.05,0.08$ and $0.10 \pm 0.01, \mathrm{P}=0.04)$ respectively. The type of supplement that was fed to lambs influenced lamb growth and fatty acid profile of tissues.

\subsection{INTRODUCTION}

The importance of time of supplementation as an aspect of feeding management strategies has been investigated for energy (Adams, 1985), protein (Barton et al., 1992; Robinson et al., 1997; and Gekara et al., 2005) and amino acid (Wiley et al., 1991; and McCracken et al., 1993) supplements. Altering the time at which protein is supplemented has been shown to affect ruminal digestion of ingested feed. Essentially, the time that a protein supplement was offered impacted diurnal changes in microbial population and ruminal digestion (Robinson et al., 1997) as well as the effectiveness of supplementation. Similarly, in experiment 1reported in this dissertation, effects of delaying a fat enriched protein supplement to 12 hours post feeding of a basal diet of orchard grass hay (0600) was observed upon ruminal digestion and digesta passage rate. Furthermore, in experiment 1 an interaction between time of supplementation and hour after hay feeding was observed for total and individual VFA, rumen $\mathrm{NH}_{3}-\mathrm{N}$ and $\mathrm{pH}$. This indicated that the supplementation strategy also affected diurnal variation of rumen metabolism, and microbial population dynamics. In addition, the $\mathrm{pH}$ values were also most consistent and generally lower in the lambs that were supplemented in the evening relative to those receiving the supplement in the morning. Wales et al., (2004) suggested the possibility of enhanced nutrient digestion when feeding strategies minimize diurnal variation at low ruminal $\mathrm{pH}$. Therefore, we hypothesized that the growth performance and tissue fatty acid composition of 
high forage finished lambs fed fat, protein or fat enriched protein supplements at a delayed time daily, will not differ.

\subsection{MATERIALS AND METHODS}

\subsection{Animals, diets, and growth performance}

The first stage of the experiment was conducted at the Reedsville Experimental Farm located in Preston County, WV. Three well-established permanent pastures, consisting of Kentucky bluegrass (Poa pratensis L.), orchardgrass (Dactilis glomerata L.), white clover (Trifolium repens L.) and red clover (Trifolium pratense L.) were used. This study used thirty three Dorset x Suffolk crossbred 3 month old lambs $(19.71 \pm 1.74 \mathrm{~kg})$, stocked at a rate of 11 (67 ewes and 5-4 wethers) lambs per hectare of pasture. After $52 \mathrm{~d}$ of grazing, and prior to initiating supplementation, pasture accessibility was improved through grazing intensification and mechanical clipping which removed dead material, floral stems and promoted vegetative tillering. Lambs were blocked by sex and weight and then randomly allocated to receive one of three supplemental treatments (Table 1). Supplements contained 0 ( $\mathrm{PR}=$ protein), 23 (FP = fat enriched protein) or $30 \%(\mathrm{~F}=$ fat) added soybean oil. Supplements were offered at 10 (F and $\mathrm{PR}$ ), and 13\% (FP) of estimated daily dry matter (4.3\% BW) intake (NRC 1985) for $30 \mathrm{~kg}$ lambs finishing at 40kg. Supplements FP and PR were designed to provide equally higher crude protein than supplement F. Supplements FP and F were designed to provide equally higher fat content than supplement PR (Table 2). Lambs accessed a fresh supply of water and were provided with mixed minerals daily prior to the supplementation period. During the supplementation period minerals were mixed into the supplements which were offered at $1600 \mathrm{~h}$ throughout the trial. Supplements were offered for the final $29 \mathrm{~d}$ of an 81 day stay on mixed pastures and then for a 
further $39 \mathrm{~d}$ in drylots. During the period of supplementation on pasture, herbage mass, herbage accumulation rate, botanical composition and forage quality were ascertained for each experimental plot (Tables 3 and 4).

The second stage of the experiment was conducted at the Livestock Experimental Farm located in Monongalia County, WV. When Lambs were 5 months old they were transferred to 3 separate drylot pens, provided with a 1: 1 mixture of alfalfa and orchard grass hay together with previously prescribed supplements, and a fresh supply of water. Supplements were offered at $1600 \mathrm{~h}$ for each day of a $39 \mathrm{~d}$ period, at the end of which a final dry lot finishing weight was taken. While in dry lots, lambs were offered hay at a minimum of $4 \%$ of their average flock BW to meet the needs of $40 \mathrm{~kg}$ lambs finishing at $50 \mathrm{~kg}$ (NRC 1985). Supplements were offered at 10 (F and PR), and 13\% (FP) of daily hay allotments.

Initial and final bodyweights were determined by averaging the weight of lambs taken on two consecutive days at the start and at the end of the study and average daily gains were determined accordingly. In addition, lambs were weighed every two weeks throughout the grazing and drylot periods. Weights reported represent weights for all lambs at the start of the grazing period, prior to and at the end of supplementation during pasture grazing and at the end of drylot feeding. Average daily gains for all lambs were determined for the period prior to and after supplementation while on pasture, during the adaptation and entire periods in the drylot. The overall ADG of all lambs for the entire duration of supplementation (TADG) are also reported. 


\subsection{Herbage mass}

During the supplementation period, measurements of herbage height were taken with the use of a $0.2 \mathrm{~m}^{2}$ plate meter (Rayburn and Rayburn, 1998). At least fifty sward height measurements were taken per experimental plot at regular intervals along three walk lines throughout the plot, staying $1 \mathrm{~m}$ from the fences. These measurements were averaged to give the sward height of the plot. The same method was used to measure residual height of each plot immediately after moving the lambs off the plots. Sward height was converted to herbage mass using the following equation (Rayburn and Rayburn, 1998):

Herbage mass $=266.15 \mathrm{X}+261.0$.

$\mathrm{X}=$ sward height

The average herbage mass data of each experimental plot for the entire duration of supplementation while on pasture is reported.

\subsection{Botanical composition}

Botanical composition of forage was determined from ten forage samples clipped from each plot during the supplementation period on pasture. Samples were taken at the start and end of the supplementation period. These ten samples were taken at regularly spaced intervals from the walk lines mentioned above. A manual hedge clipper was used to clip the forage from a $0.057 \mathrm{~m}^{2}$ quadrat placed at ground level. Samples were immediately placed into individual paper bags, labeled and transported to the laboratory where they were kept in the freezer until they were sorted. Botanical composition of samples was estimated for descriptive purposes by manually separating the ten forage samples into the following main components: grasses, legumes, weeds and senescent material. The sorted samples were oven dried at $60^{\circ} \mathrm{C}$ for 48 
hours. Dry sample weights were recorded and the biomass of each botanical component within a plot at each sampling point was calculated on a kg/ha basis (Rayburn and Rayburn, 1998). The biomass of botanical components was used to determine the percentage composition of each component within experimental plots during the supplementation period. The average botanical composition of each plot for the entire duration of supplementation is reported for descriptive purposes.

\subsection{Herbage accumulation rate}

Four grazing exclusion sites were randomly selected within each plot for placement of four grazing exclusion cages. These four grazing exclusion cages were used to determine herbage accumulation rate for each plot. At the start of the supplementation period prior to exclusion, a plate meter was used to measure forage height at four adjacent points within each exclusion site.

The latter process was repeated at each exclusion site when exclusion cages were randomly relocated in the plots. Cages were relocated twice during the supplementation period. The height measurements were used to determine herbage accumulation rates at two points during the supplementation period. The average herbage accumulation rate of each plot for the entire duration of supplementation is reported for descriptive purposes.

\subsection{Forage analysis}

Forage samples were taken daily on 5 days during each week of the final three weeks of supplementation between $1300 \mathrm{~h}$ and $1400 \mathrm{~h}$. Samples were obtained by observing lambs as they were grazing and then clipping samples from potential grazing areas. Clipped samples were placed in paper bags, weighed and then freeze dried to a constant weight, and allowed to air- 
equilibrate. Dry matter was then determined from the differences in sample weight pre and post drying. Samples were ground in a Wiley Mill (Thomas Scientific, Swedesboro, NJ) through a 1$\mathrm{mm}$ screen, and stored in plastic bags. Pasture composite samples were made for each sampling period by combining an equal weight of ground sample from each of the five day samples taken within a pasture plot. Weekly supplement samples were taken during the grazing trial and composited. The composite forage and supplement samples were then analyzed in duplicate for $\mathrm{OM}, \mathrm{CP}, \mathrm{NDF}, \mathrm{ADF}, \mathrm{ADL}, \mathrm{CP}$ and $\mathrm{EE}$ content. Organic matter was measured as weight loss following combustion for $8 \mathrm{~h}$ at $500^{\circ} \mathrm{C}$. Crude protein concentration was determined by use the Kjeldahl method. Concentrations of ash-free NDF, ADF, and ADL were determined using an Ankom 200 fiber analyzer (Ankom Technology Corp., Fairport, NY). Ether extract was determined following extraction of a $1 \mathrm{~g}$ sample with diethyl ether for $18 \mathrm{~h}$ (AOAC, 1990).

\subsection{Feeding performance in pasture and drylot}

Feeding performance data was recorded for descriptive purposes. The grazing behavior of the lambs was observed for 15 days during the supplementation period. Lambs were observed to determine if at least half of the lambs within each treatment group were grazing within $1 \mathrm{~h}$ before and after receiving supplement. Groups were judged to be grazing if half of the lambs in the group were actively grazing during the observational period. Refused supplement was weighed and the total quantity of supplement consumed each day was determined for $22 \mathrm{~d}$ during the grazing trial. The quantity of hay and supplement consumed throughout the dry lot finishing period was determined and the data for $22 \mathrm{~d}$ of the final $29 \mathrm{~d}$ of the finishing period was used for statistical analysis. All lambs except the three largest wether lambs were removed from the dry lot pens $5 \mathrm{~d}$ before those wether lambs were transported to be sacrificed. At the end of this $5 \mathrm{~d}$ 
period wethers were weighed for the final time before being sent to be sacrificed. Weekly hay and supplement samples were taken and composited. Samples were dried in a $55^{\circ} \mathrm{C}$ forced-air oven, and ground (Wiley mill; Thomas Scientific, Swedensboro, NJ) to pass through a 1-mm screen. Composite hay and supplement samples were then analyzed identically to pasture composite samples.

\subsection{Tissue collection and fatty acid determination}

Following the sacrifice of the three heaviest lambs in each treatment group (Young and Stout, Clarksburgh, W.V.) hot carcass weight was recorded before chilling the carcass at $4^{\circ} \mathrm{C}$. Dressing percentage was determined based on the final weight recorded prior to transporting lambs for sacrificing. Lamb chops and fat deposits (pelvic, kidney and heart) were obtained from each lamb and examined to determine fatty acid profiles. Muscle tissue and fat samples were immersed in liquid $\mathrm{N}$ and then ground to a fine powder using a waving blender (Fred Stein Laboratories Inc., Atchison, KS). Ground tissues were immediately transferred to Whirl Pak (Nasco, Modesto, CA) freezer bags and stored at $-80^{\circ} \mathrm{C}$. Tissue lipids were extracted by the methods of Bligh and Dyer (1959) and fatty acids were esterified in a $4 \% \mathrm{H}_{2} \mathrm{SO}_{4}$ and anhydrous methanol solution (Fritshe and Johnston, 1990). The method of Kamireddy (2004) was used to identify and quantify fatty acid methyl esters (FAME). Tissue fatty acid content was reported as mg of fatty acids detected in $1 \mathrm{~g}$ sample of each tissue. Fatty acid content of composite supplement samples was also similarly determined. 


\subsection{Data Analysis}

Two weeks prior to the end of the grazing trial, one wether lamb from the FP treatment died from non-treatment related causes. Hence, data collected beyond this point was analyzed with missing values. Data was analyzed as a completely randomized design using the GLM procedures of SAS (SAS, 2003). Each pasture or dry lot pen served as the sole experimental unit per treatment for descriptive data on botanical composition, herbage mass, herbage accumulation rate, grazing behavior, and hay or supplement intake. The model for growth performance included effects due to treatment and lamb within each pasture plot or dry lot pen served as an experimental unit. Analyses were applied to all lambs and sacrificed lambs separately. Sacrificed wether lamb served as the experimental unit for carcass and fatty acid data. There were no adjustments made for multivariate analysis. Due to the lack of true replication data should be interpreted by the reader as descriptive only. 


\subsection{RESULTS}

\subsection{Herbage mass, growth, botanical composition and quality}

Herbage mass and accumulation rates were similar amongst experimental plots (Tables 3). The average botanical composition of the experimental plots during the period of supplementation is shown in Table 4. The grass and dead material fractions of the sampled herbage represented the largest botanical components and the legume and weed fractions represented smaller components of the sampled herbage. Nutrient profile of weekly composite forage and supplement samples did not differ across treatment plots and therefore the average of all three plots are reported (Table 2). The nutrient profile of the pasture samples showed that high quality pasture was selected by all treatment groups throughout the supplementation periods. Hence, a homogenous high quality forage supply was available to all treatment groups throughout the supplementation period during grazing. Nutrient profile of orchard grass and alfalfa hay samples (Table 2) indicate that all lambs received high quality forage during the drylot feeding period.

\subsection{Feeding performance in the pasture and dry lot}

While on pasture, F $(88.63 \% / \mathrm{d})$ and FP $(88.14 \% / \mathrm{d})$ lambs consumed a greater percentage of the daily supplement than the PR lambs (81.01\%/d: Table 5). At the time of pasture supplementation, lambs in the FP $(0.00 \%)$ treatment grazed least actively immediately prior to and after supplementation, and those in the $\mathrm{F}(81.82 \%)$ group grazed more actively than those in the PR (45.45\%) group. During the first hour following supplementation, lambs in the FP $(0 \%)$ and PR ( $0 \%)$ treatment group grazed less actively than the F (36.36 \%) lambs (Table 5). During the trial period in the dry lot within each treatment group lambs completely consumed the 
supplement that was offered. The average percentage daily intake of offered forage differed across treatment groups when lambs were housed on dry lots (Table 5). Lambs offered the PR supplement had a greater percentage daily hay intake $(85.10 \% / \mathrm{d})$ than lambs provided the $\mathrm{F}$ $(81.92 \% / \mathrm{d})$ and FP $(82.14 \% / \mathrm{d})$ supplements.

\subsection{Lamb performance}

Lamb performance is shown in Table 6. Initial weight of all lambs and sacrificed wethers prior to the start of the grazing period and at the start of supplementation was similar amongst treatments $(\mathrm{P}>0.05)$ While on pasture plots, average daily gain did not differ $(\mathrm{P}>0.05)$ amongst treatment groups prior to but differed $(\mathrm{P}=0.05)$ after the supplementation period began. However, the ADG of all lambs during the entire stay on pasture was not different and so final weights at the end of the pasture grazing period were similar amongst treatments. Initial weight, and average daily gains of sacrificed wethers were similarly unaffected by treatments during the grazing period and hence final weights were not different $(P>0.05)$. Initially and during the adaptation period ( 2 weeks) in the dry lot, average daily gains were numerically greater in PR lambs than in FP lambs $(\mathrm{P}>0.05)$ and significantly greater than in $\mathrm{F}$ lambs $(\mathrm{P}<0.05)$. Amongst sacrificed wethers a similar numerical trend was observed for ADG during the adaptation period.

At the end of the dry lot feeding period all lambs and sacrificed wethers of supplemental treatment groups did not differ $(\mathrm{P}>0.05)$ in $\mathrm{ADG}$ or final weight. Consequently, overall daily gain throughout the supplementation period did not differ $(\mathrm{P}>0.05)$ in all lambs or sacrificed wethers across treatment groups. The hot carcass weights were similar across treatment groups $(\mathrm{P}>0.05)$ but estimated dressing percentages tended to differ $(\mathrm{P}=0.08)$, as the highest value 
was observed in the PR group (46.60\%) versus lower percentages in the F (44.28\%) and FP groups (43.93\%).

\subsection{Supplement and forage fatty acids}

At the time of preparing this report the fatty acid composition of the supplements and forages were not available.

\subsection{Tissue fatty acid composition}

The fatty acid composition of longissimus muscle and depots; kidney, pelvic adipose tissue, and heart tissues is shown in Table 7 to 10 . The data illustrates the $\mathrm{C} 14$ to $\mathrm{C} 18$ fatty acids profiles, and various fatty acid ratios.

Saturated fatty acids of kidney, and heart tissue and pelvic adipose tissue

Although not significant $(\mathrm{P}>0.05)$ a general trend was observed in kidney, and heart tissue and pelvic adipose tissue saturated fatty acid profiles. Of the $\mathrm{C} 14$ to $\mathrm{C} 18$ fatty acid profiled for these tissues, highest numerical values were consistently observed in either the FP or PR treatment group. Most noticeable was the myristic (C14:0), pentadecanoic (C15:0), palmitic (C16:0), heptadecanoic (C17:0), and stearic (C18:0) acids of the kidney and heart tissues. Within the kidney and heart fat the values of these five fatty acids in FP and PR lambs was about twice what they were in F lambs. Consequently, the saturated fatty acids were numerically higher in the kidney and heart tissues of FP and PR lambs relative to those of F lambs. The trend differences were also apparent in pelvic adipose tissue but to a lesser degree than in kidney and heart tissue. 
Unsaturated fatty acids of kidney, and heart tissue and pelvic adipose tissue

A similar non significant $(\mathrm{P}>0.05)$ general trend was observed in all tissues for unsaturated fatty acid with 17 or less carbon atoms. Of the $\mathrm{C} 14$ to $\mathrm{C} 17$ fatty acid profiled for these tissues highest numerical values were consistently observed in either the FP or PR treatment group. Most noticeable was the myristoleic (C14:1), palmitoleic (C16:1), acids of the kidney and heart tissues. In addition the numerical trend of cis 10- pentadecanoic $(\mathrm{C} 15: 1)$ and cis 10- heptadecanoic (C17:1) acid of the pelvic fat and cis 10- heptadecanoic (C17:1) of the kidney $(P=0.08)$ showed a tendency to differ amongst treatments. Predominately the values observed in the kidney and heart fat for $\mathrm{C} 14$ through $\mathrm{C} 17$ unsaturated fatty acids in FP and PR lambs was about twice what was observed in $\mathrm{F}$ lambs. Once again the trend differences was also apparent in pelvic tissue but to a lesser degree than in kidney and heart tissue.

In comparing numerical but nonsignificant trends of the $\mathrm{C} 18$ unsaturated fatty acids certain similarities to what were observed in the saturated fatty acid and unsaturated C14 to C17 fatty acids profiles were observable but important differences were noted. Oleic acid (C18:1n9c) in kidney $(\mathrm{P}=0.09)$ and heart fat of $\mathrm{FP}$ and $\mathrm{PR}$ lambs was twice as much as what was observed in those tissues in F lambs. A similar trend was observed for oleic acid in pelvic tissue but the magnitude of the difference was smaller. Linolelaidic (C18:2:n6t), linoleic (C18:2n6c), and linolenic (C18:3n3) of kidney fat adhered to the general trend as FP and PR lambs showed numerically higher values to F lambs. In contrast only linoleic (C18:2n6c), and linolenic (C18:3n3) of heart fat adhered to the general trend. In pelvic fat the linolelaidic (C18:2:n6t), linoleic (C18:2n6c), and linolenic (C18:3n3) was noticeably highest in FP lambs relative to PR and F lambs. Gamma $(\gamma)$ linolenic (C18:3n6) acid was detected in the kidney and pelvic but not 
the heart fat. The higher values observed in the kidney were clearly indifferent across treatments but in the pelvic fat the FP lambs displayed numerically superior values to the other treatments by a factor of approximately two. Elaidic acid (C18:1n9t) values in both the kidney and pelvic fat were lowest in PR, intermediate in F and highest in FP lambs. Cumulatively, the total unsaturated fatty acid of kidney and heart fat of FP and PR lambs was about twice that of F lambs. In pelvic fat the total unsaturated fat was numerically higher in FP lambs than in PR and F lambs.

\subsection{Muscle fatty acid profile}

In muscle tissue the pattern observed for individual saturated and unsaturated fatty acids in other tissues was apparent but of a much smaller magnitude than the order of approximately two. The heptadecanoic (C17:0), elaidic acid (C18:1n9t) and linoleic (C18:2n6c) of muscle tissue represented exceptions to this general trend as F lambs had the numerically highest quantities of these fatty acids. The total saturated fatty acid (SFA), were higher in FP lambs and similar in PR and F lamb muscle. The total unsaturated fatty acid (UFA), monounsaturated fatty acid (MUFA), polyunsaturated fatty acids (PUFA), and n6 fatty acids were similar among treatments with F lamb muscle values being numerically superior. Notably, the SFA: UFA ratio was similar to what was observed in heart fat, where FP and PR lambs had numerically higher values. Similarly the MUFA: PUFA ratio adhered to the trend observed in kidney and heart tissue and pelvic adipose tissue fat, wherein, highest numerical values were observed in PR lamb than in F and FP lambs. Conversely, neither $\mathrm{n} 3$ fatty acid values nor n6: $\mathrm{n} 3$ ratio differed amongst lambs. The PUFA: SFA ratio was higher $(\mathrm{P}=0.04)$ in $\mathrm{F}$ and FP kidney and predominately higher in $\mathrm{F}$ and FP pelvic $(\mathrm{P}=0.20)$ and muscle $(\mathrm{P}=0.21)$ relative to $\mathrm{PR}$ lambs. 


\subsection{DISCUSSION}

\subsection{Average daily gains}

Lack of differences in herbage quality, herbage mass, and herbage accumulation rate across plots during the supplementation period indicates that a homogenous basal diet was available to all lambs. Differences $(\mathrm{P}=0.05)$ in $\mathrm{ADG}(\mathrm{F}=0.30, \mathrm{FP}=0.27, \mathrm{PR}=0.22 \pm 0.02$ $\mathrm{kg} / \mathrm{d}$ ) during the $29 \mathrm{~d}$ of supplementation on pasture indicate that delayed fat enriched supplement promoted higher daily gains than the protein supplement. The differences in growth rates might be related to differences in percentage supplement consumption $(\mathrm{F}=88.63, \mathrm{PR}=$ $81.01, \mathrm{FP}=88.14 \pm 2.42 \%)$ and grazing activity prior to $(\mathrm{F}=82.82, \mathrm{PR}=45.45, \mathrm{FP}=0.00 \pm$ $12.50 \%)$ and after $(\mathrm{F}=36.36, \mathrm{PR}=0.00, \mathrm{FP}=0.00 \pm 8.78 \%)$ the time of daily supplementation.

Possible palatability or acceptability issues might account for the differences in supplement consumption observed while lambs were on pasture but the observed differences in grazing behavior indicate that even more intense chemiostatic mechanisms (Dove, 1988, Relling and Reynolds, 2007) might have affected supplement consumption and grazing activity. Prior to offering the daily supplement the grazing activity was lower in the lambs supplemented with higher crude protein (FP and PR). After supplementation the lambs fed the lowest crude protein supplement (F) and lambs fed protein devoid of oil (PR) returned to active grazing sooner than lambs fed the oil enriched protein supplement (FP). The latter might be primarily due to the fact that the FP lambs consumed a larger percent of estimated daily feed intake at supplementation. Conversely, lambs fed the F supplement seemed to graze most actively around the time of supplementation possibly indicating a greater reliance on selective grazing to fulfill their daily protein requirements. Likewise PR lambs probably returned to grazing sooner than FP lambs 
because of a need to meet daily energy or even protein requirements. Arguably, supplementation with protein supplements (FP and PR), especially when synchronized with fat supplementation (FP), temporarily reduced the tendency for grazing. Reduced grazing would mean reduced usage of energy for locomotion and feed apprehension which would have positively affected lamb growth (Krysl and Hess, 1993; Canton and Dhuyvetter, 1997).

Alternatively, providing supplemental energy (F) or energy and protein (FP) may have had a greater positive impact on lamb growth because intake and digestion of both nutrients were synchronized (Cuitun et al., 1975). Lambs in the F treatment returned to grazing to acquire protein whereas FP lambs did not. Under pasture grazing conditions metabolizable energy intake has been reported (Krysl and Hess, 1993; Canton and Dhuyvetter, 1997) to be a growth limiting factor. The prospect of occurrence of metabolizable energy insufficiency was probably greater as opposed to protein insufficiency for these grazing ruminants. Indeed, the data indicated the F lambs achieved similar average daily gains on pasture as FP lambs even though the F supplement contained lower crude protein. Further supporting the latter suggestion is the numerically higher average daily gain of lambs fed fat enriched supplements $(\mathrm{F}=0.24$ and $\mathrm{FP}=0.25 \pm 0.01 \mathrm{~kg} / \mathrm{d})$ compared to the PR $(0.21 \pm 0.01 \mathrm{~kg} / \mathrm{d})$ lambs at the end of the pasture grazing period. Arguably, such small but insignificant additional weight gains might have been attributable to differences in fat deposition, gut fill or a combination of both across treatment groups at this point in the trial.

Supplement consumption did not differ but percentage hay consumed $(\mathrm{F}=81.92, \mathrm{PR}=$ $85.10, \mathrm{FP}=82.14 \pm 0.79 \%$ ) differed across treatments. The PR lambs consumed higher percentages of hay and achieved numerically higher average daily gains than F and FP lambs $(0.14,0.07,0.10 \pm 0.02 \mathrm{~kg} / \mathrm{d}$ respectively). This numerically higher average daily gain might be 
mostly attributable to the significantly $(\mathrm{P}<0.05)$ higher average daily gain of $\mathrm{PR}$ lambs as oppose to FP and F lambs during the initial 2 weeks of rearing on drylot $(0.23,0.11$ and $-0.05 \pm$ $0.05 \mathrm{~kg} / \mathrm{d}$ respectively). This growth trend represented a reversal of what was observed while lambs were supplemented on pasture. During the period on dry lot protein supplementation might have been more important than energy supplementation and consequently PR lambs achieved similar finished weights to F and FP lambs by the end of the entire feeding trial. In addition, while in the drylot with the forage supplied to lambs, the ability to effectively select might have been reduced, which possibly led to inadequate daily protein intake in lambs fed fat enriched supplements. Within the fat supplemented groups a reduction in daily protein intake would have been more likely to have affected the F lambs than the FP lambs.

Even though neither average daily gain of all lambs or sacrificed wether lambs differed across treatment groups by the end of the drylot trial period (Table 6), numerical trends $(\mathrm{P}=$ 0.08) indicated lower dressing percentages for F and FP wethers compared to PR lambs. Plausibly, slower digestion, reduced digesta passage rates and consequently greater gut fill in lambs fed fat enriched supplements resulted in inflated weight measurements. Likewise the apparently higher gains of lambs fed fat enriched supplements while on pasture might also have been attributed to the greater gut fill. Even more likely, the data suggest possibly higher levels of visceral fat deposition occurred in the fat supplemented treatments. Hence, the absence of differences in $\mathrm{ADG}$ at the end of this feed trial might be attributable to a combination of factors. Despite the absence of differences in ADG throughout the supplementation period, the contribution of lean and fat to the overall weight gains probably differed amongst treatments. Plausibly the rates of gain observed in protein supplemented lambs (PR and FP) might be associated with higher rates of both lean and fat tissue accretion as compared to F lambs during 
the drylot feeding period. In addition the negative gains achieved by all lambs and sacrificed wethers in $\mathrm{F}$ lambs during the adaptation period were most likely associated with loss of adipose tissue which might not have been recovered during the remainder of the feeding trial. Indeed, amongst sacrificed wethers neither ADG during the feedlot period nor total ADG for the entire supplementation period differed amongst treatments. The impact of ruminal digestive activity, rates of daily gain and duration of finishing in dry lot on muscle fatty acid profile has been previously emphasized (Aurousseau et al., 2006) and similar effects might be apparent in this study.

\subsection{Saturated fatty acids of kidney, and heart tissue and pelvic adipose tissue}

The general trend of consistently higher numerical values of the C14 to C18 saturated fatty acid in kidney, and heart tissue and pelvic adipose tissue of the FP and PR treatment group indicated the possibility of growth associated effects. The supplemental protein provided to both groups could have induced small statistically insignificant growth increases which would result in increased deposition of fat and thus explain the trend difference in saturated fatty acid profile. Indeed, within the kidney myristic acid $(\mathrm{C} 14: 0)$ tended to be greater $(\mathrm{P}=0.08)$ in $\mathrm{FP}$ and $\mathrm{PR}$ $(1.18$ and $1.65 \pm 0.26 \mathrm{mg} / \mathrm{g})$ lambs than in $\mathrm{F}(0.68 \pm 0.26 \mathrm{mg} / \mathrm{g})$ lambs. In addition, kidney and heart pentadecanoic (C15:0), palmitic (C16:0), heptadecanoic (C17:0), and stearic (C18:0) acids of FP and PR lambs was about twice what they were in F lambs further suggesting the effects of differential rates of fat accretion across treatment groups. It might be that the feeding of protein at a delayed time effected enhanced protein degradation (Robinson et al., 1997) fostering enhanced growth and fat deposition. The apparently different quantities of these five saturated fatty acids detected in the various treatment groups might also indirectly reflect enhanced 
microbial activity and fatty acid biohydrogenation within the rumen of protein supplemented lambs. Consequently, the total saturated fatty acids appeared higher in the kidney and heart tissues of FP and PR lambs than in F lamb tissues suggesting the possibility of growth related effects on fat deposition. Of all three tissues the pelvic depot would be the last for fat accretion to occur (Allen et al., 1978) and hence at the time of slaughter fat accretion probably had not progressed to a point where apparent differences observed in internal organ fat were even minutely evident in pelvic fat.

\subsection{Unsaturated fatty acids of kidney, and heart tissue and pelvic adipose tissue}

A general trend similar to what was observed for saturated fatty acids was observed in kidney, and heart tissue and pelvic adipose tissues for unsaturated fatty acid with 17 or less carbon atoms. This trend might also be related to growth effects as the highest numerical values of $\mathrm{C} 14$ to $\mathrm{C} 17$ fatty acid were consistently observed in either the FP or PR treatment groups. These values were also at most about twice what was observed in F lambs. Trend differences were also apparent to a lesser degree in pelvic tissue than in kidney and heart tissues.

Suggestively, superior growth and fat accretion occurred in FP and PR lambs. The prevalent trend was best evidenced with cis 10- heptadecanoic (C17:1) of the kidney where PR lambs tended to have the highest $(\mathrm{P}=0.08)$ values amongst all treatment lambs. This trend might relate not only to the supplemental protein promoting enhanced growth but also enhanced microbial activity, and modification of ingested fats.

In comparing numerical trends of the $\mathrm{C} 18$ unsaturated fatty acids certain similarities to what were observed in the saturated fatty acid and unsaturated $\mathrm{C} 14$ to $\mathrm{C} 17$ fatty acids profiles exist with important differences being noted. The trend was most evident for the 
monounsaturated fatty acid; oleic acid $(\mathrm{C} 18: \ln 9 \mathrm{c})$ in kidney $(\mathrm{P}=0.09)$ and heart $(\mathrm{P}=0.11)$ fat of FP and PR lambs was almost twice as much as in those tissues in F lambs and only remotely apparent in pelvic tissue, once again suggesting the impact of growth effects on fatty acid profile. Contrastingly, elaidic acid (C18:1n9t) values in both the kidney and pelvic fat were lowest in PR, intermediate in $\mathrm{F}$ and highest in FP lambs indicating possible effects of growth, microbial biohydrogenation, and supplementing lambs with fat. The apparent trend differences amongst the polyunsaturated C18 fatty acids linolelaidic (C18:2:n6t), linoleic (C18:2n6c), and linolenic (C18:3n3) of kidney and heart fat also reinforced the possibility of growth associated effects upon fatty acid profile. Interestingly, trend differences for C18 polyunsaturated fatty acids in the pelvic fat digressed somewhat from what was observed for the saturated, and monounsaturated fatty acids. The values for linolelaidic (C18:2:n6t), linoleic (C18:2n6c), and linolenic (C18:3n3) declined from FP, to F and then PR lambs suggesting possible effects of supplemental fat on fatty acid profile and an additive effect of growth upon supplemental fat effects. Also, kidney and heart tissue and pelvic adipose tissue $\gamma$ linolenic $(\mathrm{C} 18: 3 \mathrm{n} 6)$ acid was detected in greatest quantities in the kidney, but not the heart. In the pelvic fat the FP lambs displayed numerically superior values of $\gamma$ linolenic (C18:3n6) by a factor of approximately two suggesting combined effects of differential growth and fat supplementation. Cumulatively, the total unsaturated fatty acid of kidney and heart fat of FP and PR lambs was about twice that of F lambs but in pelvic fat the total unsaturated fat was numerically higher in FP lambs than in PR and F lambs suggesting a combination of growth effects and supplemental fat effects on fatty acid profiles. 


\subsection{Muscle fatty acid profile and fatty acid ratios}

In muscle tissue, detection of similar but less magnified trends for individual saturated and unsaturated fatty acids, together with the contrasting trend for elaidic $(\mathrm{C} 18: 1 \mathrm{n} 9 \mathrm{t} ; \mathrm{P}=0.09)$ and linoleic (C18:2n6c) acid suggest that supplemental fat was probably effective in affecting differences in fatty acid profile across treatments and that growth effects were not as effective as in other tissues. Indeed, despite a minutely superior total saturated fatty acid (SFA) value in FP lambs relative to PR and F lambs, the total unsaturated fatty acid (UFA), monounsaturated fatty acid (MUFA), polyunsaturated fatty acids (PUFA), and n6 fatty acids were numerically superior in F lamb muscle. Notably, the SFA: UFA ratio was lower $(\mathrm{P}=0.02)$ in $\mathrm{F}$ lamb muscles than in FP and PR lambs, and this trend was similar to that of kidney and heart tissue and pelvic adipose tissue fat further supporting the idea of supplemental fat affecting muscle fatty acid profile to a greater extent than growth associated effects. Similarly the lower MUFA: PUFA ratio in pelvic $(\mathrm{P}=0.08)$ fat in $\mathrm{F}$ and FP lambs relative to that of $\mathrm{PR}$ lambs indicates effects of fat supplementation. Higher $(\mathrm{P}=0.07) \mathrm{n} 6: \mathrm{n} 3$ ratio in $\mathrm{F}$ lambs than in $\mathrm{FP}$ and $\mathrm{PR}$ lambs in muscle also indicates effects of fat supplementation. Furthermore, the PUFA: SFA ratio was higher in kidney ( $\mathrm{P}=0.04)$, of $\mathrm{F}$ and $\mathrm{FP}$ lambs relative to $\mathrm{PR}$ lambs, once again suggesting effects of supplementing fat.

\subsection{SUMMARY}

Lamb management strategy, especially supplementation influenced grazing, forage intake, lamb lean and fat tissue growth and thus fatty acid profile of all tissues. Lambs could be finished on pasture using delayed supplementation of 3\% soybean oil mixed into a low crude 
protein fiber carrier and this may enhance muscle fatty acid profile at a more economical cost than a fat enriched protein or protein supplement.

Table 1. Ingredient composition of supplemental treatments ${ }^{1}$ used in experiment 2

\begin{tabular}{l|lll}
\hline \multicolumn{3}{c}{ Treatments } \\
\hline Ingredient (\%) & Fat & Protein & Fat and protein \\
\cline { 2 - 4 } Soybean oil & 30.00 & 0 & 23.00 \\
Soybean hull & 69.99 & 49.99 & 38.64 \\
Soybean meal & 0.00 & 49.99 & 38.64 \\
\hline
\end{tabular}

${ }^{1}$ Mixed mineral and Bovatec was included at equal levels in all supplements

Table 2. Nutrient profile of supplements, and forage used in experiment 2

\begin{tabular}{l|llllll}
\hline \multicolumn{2}{c}{ Supplemental Treatments } & \multicolumn{3}{l}{ Forage } \\
\hline Nutrient (\%) & Fat & Protein & $\begin{array}{l}\text { Fat and } \\
\text { Protein }\end{array}$ & $\begin{array}{l}\text { Pasture } \\
\text { Forage }\end{array}$ & $\begin{array}{l}\text { Orchard } \\
\text { grass }\end{array}$ & Alfalfa \\
DM & 90.99 & 88.87 & 92.65 & 30.06 & 83.13 & 82.43 \\
NM & 90.32 & 88.02 & 92.88 & 91.49 & 93.69 & 92.09 \\
ADF & 55.35 & 38.10 & 32.13 & 44.12 & 70.97 & 42.77 \\
ADL & 33.71 & 23.87 & 18.62 & 22.08 & 36.86 & 30.84 \\
CP & 3.63 & 0.30 & 0.07 & 1.63 & 4.38 & 7.30 \\
Ash & 7.56 & 30.26 & 20.35 & 25.91 & 15.46 & 23.46 \\
Ether Extract & 9.68 & 11.98 & 7.12 & 8.51 & 6.31 & 7.91 \\
\end{tabular}

Table 3. Herbage mass and herbage accumulation of each experimental plot during supplementation

\begin{tabular}{|c|c|c|c|c|c|}
\hline \multicolumn{6}{|c|}{ Treatments } \\
\hline Variable & Fat & Protein & $\begin{array}{l}\text { Fat and } \\
\text { Protein }\end{array}$ & $\pm \mathrm{SE}$ & P-value \\
\hline $\begin{array}{l}\text { Herbage mass }{ }^{1} \\
(\mathrm{~kg} / \mathrm{ha})\end{array}$ & 4088.79 & 4072.49 & 3929.45 & 344.07 & 0.94 \\
\hline $\begin{array}{l}\text { Herbage }^{2} \\
\text { accumulation } \\
\text { rate }(\mathrm{kg} / \mathrm{ha} / \mathrm{d})\end{array}$ & 89.83 & 100.26 & 92.20 & 6.68 & 0.53 \\
\hline
\end{tabular}


Table 4. Botanical composition ${ }^{1}$ of experimental plots during supplementation

\begin{tabular}{ll}
\hline Component & Percentage (\%) \\
\hline Grass & 56.32 \\
Legume & 5.25 \\
Weed & 4.56 \\
Dead & 33.87 \\
\hline
\end{tabular}

${ }^{1}$ Botanical composition of forage was determined from forage samples clipped from each plot during the supplementation period on pasture.

Table 5. Feeding performance of lambs on pasture and in drylots

\begin{tabular}{|c|c|c|c|}
\hline & \multicolumn{3}{|c|}{ Treatments } \\
\hline Pasture Variables & Fat & Protein & Fat and Protein \\
\hline Supplement offered (kg/lamb/d) & 0.16 & 0.16 & 0.20 \\
\hline Supplement intake $(\mathrm{kg} / \mathrm{lamb} / \mathrm{d})$ & 0.14 & 0.13 & 0.18 \\
\hline Percent supplement intake $(\%)$ & 88.63 & 81.01 & 88.14 \\
\hline Grazing before (\%) & 82.82 & 45.45 & 0.00 \\
\hline Grazing after $(\%)$ & 36.36 & 0.00 & 0.00 \\
\hline \multicolumn{4}{|l|}{ Drylot Variables } \\
\hline Hay offered (kg/lamb/d) & 1.70 & 1.70 & 1.70 \\
\hline Hay intake (kg/lamb/d) & 1.40 & 1.45 & 1.40 \\
\hline Percent hay intake (\%) & 81.92 & 85.10 & 82.14 \\
\hline Supplement offered $(\mathrm{kg} / \mathrm{lamb} / \mathrm{d})$ & 0.17 & 0.17 & 0.22 \\
\hline Supplement intake $(\mathrm{kg} / \mathrm{lamb} / \mathrm{d})$ & 0.17 & 0.17 & 0.22 \\
\hline Percent supplement intake (\%) & 100 & 100 & 100 \\
\hline
\end{tabular}


Table 6. Performance of all lambs ${ }^{\mathrm{L}}$, and sacrificed wethers ${ }^{\mathrm{W}}$ while on pasture and in drylots

\begin{tabular}{|c|c|c|c|c|c|}
\hline \multicolumn{6}{|c|}{ Treatments } \\
\hline Pasture variables & Fat & Protein & $\begin{array}{l}\text { Fat and } \\
\text { Protein }\end{array}$ & $\pm \mathrm{SE}$ & P-value \\
\hline Initial weight $^{\mathrm{L}}(\mathrm{kg})$ & 20.16 & 19.42 & 19.54 & 1.74 & 0.95 \\
\hline $\begin{array}{l}\text { Weight }{ }^{\mathrm{L}} \text { at start } \\
\text { supplementation }(\mathrm{kg})\end{array}$ & 31.08 & 30.34 & 32.02 & 1.64 & 0.86 \\
\hline $\begin{array}{l}\mathrm{ADG}^{\mathrm{L}} \text { before } \\
\text { supplementation }(\mathrm{kg} / \mathrm{d})\end{array}$ & 0.21 & 0.21 & 0.24 & 0.01 & 0.25 \\
\hline $\begin{array}{l}\mathrm{ADG}^{\mathrm{L}} \text { after supplementation } \\
(\mathrm{kg} / \mathrm{d})\end{array}$ & 0.30 & 0.22 & 0.27 & 0.02 & 0.05 \\
\hline Final weight ${ }^{\mathrm{L}}(\mathrm{kg})$ & 39.66 & 36.69 & 38.50 & 2.07 & 0.60 \\
\hline $\mathrm{ADG}^{\mathrm{L}}(\mathrm{kg} / \mathrm{d})$ & 0.24 & 0.21 & 0.25 & 0.01 & 0.16 \\
\hline Initial weight $^{\mathrm{W}}(\mathrm{kg})$ & 24.79 & 24.04 & 18.75 & 2.11 & 0.17 \\
\hline $\begin{array}{l}\text { Weight }{ }^{\mathrm{W}} \text { at start } \\
\text { supplementation }(\mathrm{kg})\end{array}$ & 36.23 & 37.56 & 31.75 & 2.35 & 0.14 \\
\hline $\begin{array}{l}\mathrm{ADG}^{\mathrm{W}} \text { before } \\
\text { supplementation }(\mathrm{kg} / \mathrm{d})\end{array}$ & 0.22 & 0.26 & 0.25 & 0.03 & 0.57 \\
\hline $\begin{array}{l}\mathrm{ADG}^{\mathrm{W}} \text { after supplementation } \\
(\mathrm{kg} / \mathrm{d})\end{array}$ & 0.31 & 0.23 & 0.23 & 0.03 & 0.16 \\
\hline Final weight ${ }^{\mathrm{W}}(\mathrm{kg})$ & 45.35 & 44.14 & 38.40 & 2.45 & 0.18 \\
\hline $\mathrm{ADG}^{\mathrm{W}}(\mathrm{kg} / \mathrm{d})$ & 0.25 & 0.25 & 0.24 & 0.02 & 0.95 \\
\hline \multicolumn{6}{|l|}{ Drylot variables } \\
\hline $\begin{array}{l}\mathrm{ADG}^{\mathrm{L}} \text { during adaptation } \\
(\mathrm{kg} / \mathrm{d})\end{array}$ & $-0.05^{b}$ & $0.23^{\mathrm{a}}$ & $0.11^{\mathrm{a}}$ & 0.05 & 0.003 \\
\hline Final weight ${ }^{\mathrm{L}}(\mathrm{kg})$ & 41.81 & 41.06 & 41.77 & 1.99 & 0.96 \\
\hline $\mathrm{ADG}^{\mathrm{L}}(\mathrm{kg} / \mathrm{d})$ & 0.07 & 0.14 & 0.10 & 0.03 & 0.31 \\
\hline $\begin{array}{l}\mathrm{ADG}^{\mathrm{W}} \text { during adaptation } \\
(\mathrm{kg} / \mathrm{d})\end{array}$ & -0.05 & 0.18 & 0.24 & 0.09 & 0.13 \\
\hline Final weight ${ }^{\mathrm{W}}(\mathrm{kg})$ & 50.19 & 48.98 & 46.11 & 3.30 & 0.69 \\
\hline $\mathrm{ADG}^{\mathrm{W}}(\mathrm{kg} / \mathrm{d})$ & 0.18 & 0.17 & 0.21 & 0.02 & 0.38 \\
\hline${ }^{1} \mathrm{TADG}^{\mathrm{L}}(\mathrm{kg} / \mathrm{lamb} / \mathrm{d})$ & 0.16 & 0.15 & 0.16 & 0.01 & 0.83 \\
\hline${ }^{1} \mathrm{TADG}^{\mathrm{W}}(\mathrm{kg} / \mathrm{lamb} / \mathrm{d})$ & 0.21 & 0.17 & 0.21 & 0.02 & 0.38 \\
\hline Hot weight $^{\mathrm{W}}(\mathrm{kg})$ & 22.22 & 22.83 & 20.26 & 1.69 & 0.57 \\
\hline Dressing Percentage $^{\mathrm{W}}(\%)$ & 44.27 & 46.62 & 43.85 & 0.76 & 0.08 \\
\hline
\end{tabular}

\footnotetext{
${ }^{1}$ TADG. Overall ADG determined for entire duration of supplementation

${ }^{\mathrm{a}, \mathrm{b}}$ Within a row means without a common superscript letter differ $(\mathrm{P}<0.05)$

L All lambs, ${ }^{\mathrm{W}}$ Sacrificed wethers
} 
Table 7. Fatty acid profile of longissimus muscle harvested from sacrificed wethers

\begin{tabular}{|c|c|c|c|c|c|}
\hline & \multicolumn{5}{|c|}{ Treatments } \\
\hline Fatty acid (mg/g) & Fat & Protein & $\begin{array}{l}\text { Fat and } \\
\text { protein }\end{array}$ & $\pm S E$ & P-value \\
\hline Myristic & 0.95 & 1.22 & 1.12 & 0.27 & 0.77 \\
\hline Myristoleic & - & - & - & - & - \\
\hline Pentadecanoic & 0.28 & 0.31 & 0.40 & 0.06 & 0.44 \\
\hline cis-10-Pentadecanoic & - & - & - & - & - \\
\hline Palmitic & 9.53 & 10.09 & 11.18 & 1.78 & 0.81 \\
\hline Palmitoleic & 0.78 & 0.73 & 0.78 & 0.18 & 0.98 \\
\hline Heptadecanoic & 1.58 & 0.75 & 0.90 & 0.49 & 0.49 \\
\hline cis-10-Heptadecanoic & 0.10 & 0.18 & 0.13 & 0.05 & 0.59 \\
\hline Stearic & 9.84 & 10.12 & 14.20 & 1.68 & 0.20 \\
\hline Elaidic & 8.95 & 4.07 & 4.18 & 1.48 & 0.10 \\
\hline Oleic & 10.66 & 11.95 & 12.74 & 2.17 & 0.80 \\
\hline Linolelaidic & 0.12 & 0.12 & 0.13 & 0.03 & 0.98 \\
\hline Linoleic & 1.96 & 1.39 & 1.61 & 0.34 & 0.52 \\
\hline$\gamma$-Linolenic & - & - & - & - & - \\
\hline Linolenic & 0.53 & 0.55 & 0.73 & 0.10 & 0.35 \\
\hline Saturated & 22.18 & 22.48 & 27.80 & 3.56 & 0.50 \\
\hline Unsaturated (UFA) & 23.10 & 18.98 & 20.29 & 3.59 & 0.72 \\
\hline MUFA & 20.48 & 16.93 & 17.83 & 3.16 & 0.72 \\
\hline PUFA & 2.62 & 2.05 & 2.46 & 0.46 & 0.68 \\
\hline n6 & 2.08 & 1.50 & 1.74 & 0.37 & 0.58 \\
\hline $\mathrm{n} 3$ & 0.53 & 0.55 & 0.73 & 0.10 & 0.35 \\
\hline \multicolumn{6}{|l|}{ Fatty acid ratios } \\
\hline SFA/UFA & $0.98^{\mathrm{a}}$ & $1.22^{\mathrm{b}}$ & $1.38^{\mathrm{b}}$ & 0.07 & 0.02 \\
\hline MUFA/PUFA & 7.82 & 8.25 & 7.23 & 0.55 & 0.29 \\
\hline $\mathrm{n} 6 / \mathrm{n} 3$ & 3.88 & 2.64 & 2.40 & 0.39 & 0.07 \\
\hline PUFA/SFA & 0.12 & 0.09 & 0.09 & 0.01 & 0.21 \\
\hline
\end{tabular}

${ }^{\mathrm{a}, \mathrm{b}}$ For each tissue, within a row means without a common superscript letter $\operatorname{differ}(\mathrm{P}<0.05)$ 
Table 8. Fatty acid profile of heart tissue harvested from sacrificed wethers

\begin{tabular}{|c|c|c|c|c|c|}
\hline & \multicolumn{5}{|c|}{ Treatments } \\
\hline Fatty acid (mg/g) & Fat & Protein & $\begin{array}{l}\text { Fat and } \\
\text { protein }\end{array}$ & $\pm S E$ & P-value \\
\hline Myristic & 1.39 & 2.26 & 2.45 & 0.81 & 0.61 \\
\hline Myristoleic & 0.07 & 0.16 & 0.20 & 0.08 & 0.42 \\
\hline Pentadecanoic & 0.20 & 0.43 & 0.52 & 0.18 & 0.43 \\
\hline cis-10-Pentadecanoic & - & - & - & - & - \\
\hline Palmitic & 8.13 & 15.81 & 17.29 & 5.00 & 0.40 \\
\hline Palmitoleic & 0.53 & 0.96 & 1.30 & 0.44 & 0.46 \\
\hline Heptadecanoic & 0.57 & 1.24 & 1.44 & 0.39 & 0.29 \\
\hline cis-10-Heptadecanoic & 0.52 & 0.53 & 0.66 & 0.15 & 0.72 \\
\hline Stearic & 9.55 & 22.04 & 24.10 & 6.55 & 0.28 \\
\hline Elaidic & - & - & - & - & - \\
\hline Oleic & 12.91 & 25.89 & 24.53 & 4.06 & 0.11 \\
\hline Linolelaidic & 0.09 & 0.27 & 0.09 & 0.12 & 0.43 \\
\hline Linoleic & 3.06 & 5.04 & 5.81 & 1.67 & 0.49 \\
\hline$\gamma$-Linolenic & - & - & - & - & - \\
\hline Linolenic & 0.63 & 1.13 & 1.26 & 0.25 & 0.33 \\
\hline Saturated & 19.85 & 41.79 & 45.81 & 12.87 & 0.34 \\
\hline Unsaturated (UFA) & 17.80 & 33.98 & 33.85 & 6.60 & 0.20 \\
\hline MUFA & 14.03 & 27.54 & 26.70 & 4.63 & 0.14 \\
\hline PUFA & 3.77 & 6.44 & 7.16 & 2.02 & 0.47 \\
\hline n6 & 3.15 & 5.31 & 5.90 & 1.75 & 0.51 \\
\hline n3 & 0.63 & 1.13 & 1.25 & 0.30 & 0.33 \\
\hline \multicolumn{6}{|l|}{$\underline{\text { Fatty acid ratios }}$} \\
\hline SFA/UFA & 1.12 & 1.23 & 1.35 & 0.15 & 0.65 \\
\hline MUFA/PUFA & 3.72 & 4.28 & 3.73 & 0.61 & 0.59 \\
\hline n6/n3 & 5.02 & 4.70 & 4.71 & 1.06 & 0.74 \\
\hline PUFA/SFA & 0.19 & 0.15 & 0.16 & 0.02 & 0.33 \\
\hline
\end{tabular}


Table 9. Fatty acid profile of kidney tissue harvested from sacrificed wethers

\begin{tabular}{|c|c|c|c|c|c|}
\hline & \multicolumn{5}{|c|}{ Treatments } \\
\hline Fatty acid (mg/g) & Fat & Protein & $\begin{array}{l}\text { Fat and } \\
\text { Protein }\end{array}$ & $\pm S E$ & P-value \\
\hline Myristic & 0.68 & 1.65 & 1.18 & 0.26 & 0.08 \\
\hline Myristoleic & 0.07 & 0.25 & 0.16 & 0.11 & 0.48 \\
\hline Pentadecanoic & 0.25 & 0.58 & 0.47 & 0.19 & 0.47 \\
\hline cis-10-Pentadecanoic & - & - & - & - & - \\
\hline Palmitic & 6.05 & 14.59 & 10.99 & 3.75 & 0.30 \\
\hline Palmitoleic & 0.14 & 0.79 & 0.51 & 0.30 & 0.32 \\
\hline Heptadecanoic & 0.49 & 1.77 & 1.01 & 0.58 & 0.30 \\
\hline cis-10-Heptadecanoic & 0.05 & 0.44 & 0.11 & 0.10 & 0.08 \\
\hline Stearic & 10.24 & 26.32 & 20.22 & 9.19 & 0.46 \\
\hline Elaidic & 5.70 & 4.43 & 11.18 & 2.67 & 0.17 \\
\hline Oleic & 6.90 & 18.05 & 12.13 & 2.53 & 0.09 \\
\hline Linolelaidic & 0.07 & 0.21 & 0.25 & 0.12 & 0.57 \\
\hline Linoleic & 0.80 & 1.36 & 2.05 & 0.49 & 0.23 \\
\hline$\gamma$-Linolenic & 0.32 & 0.36 & 0.34 & 0.24 & 0.99 \\
\hline Linolenic & 0.15 & 0.33 & 0.62 & 0.31 & 0.52 \\
\hline Saturated & 17.71 & 44.90 & 33.87 & 13.91 & 0.39 \\
\hline Unsaturated (UFA) & 14.21 & 26.20 & 27.34 & 6.65 & 0.33 \\
\hline MUFA & 12.86 & 23.95 & 24.09 & 5.72 & 0.32 \\
\hline PUFA & 1.34 & 2.25 & 3.26 & 0.82 & 0.28 \\
\hline n6 & 1.19 & 1.92 & 2.63 & 0.67 & 0.33 \\
\hline $\mathrm{n} 3$ & 0.15 & 0.33 & 0.62 & 0.31 & 0.52 \\
\hline \multicolumn{6}{|l|}{$\underline{\text { Fatty acid ratios }}$} \\
\hline SFA/UFA & 1.25 & 1.71 & 1.24 & 0.24 & 0.30 \\
\hline MUFA/PUFA & 9.59 & 10.63 & 7.40 & 1.53 & 0.13 \\
\hline $\mathrm{n} 6 / \mathrm{n} 3$ & 8.03 & 5.80 & 4.22 & 24.19 & 0.88 \\
\hline PUFA/SFA & $0.08^{\mathrm{a}}$ & $0.05^{\mathrm{b}}$ & $0.10^{\mathrm{a}}$ & 0.01 & 0.04 \\
\hline
\end{tabular}

\footnotetext{
${ }^{\mathrm{a}, \mathrm{b}}$ For each tissue, within a row means without a common superscript letter $\operatorname{differ}(\mathrm{P}<0.05)$
} 
Table 10. Fatty acid profile of pelvic adipose tissue harvested from sacrificed wethers

\begin{tabular}{|c|c|c|c|c|c|}
\hline & \multicolumn{5}{|c|}{ Treatments } \\
\hline Fatty acid (mg/g) & Fat & Protein & $\begin{array}{l}\text { Fat and } \\
\text { protein }\end{array}$ & $\pm S E$ & P-value \\
\hline Myristic & 1.42 & 1.87 & 1.59 & 0.46 & 0.81 \\
\hline Myristoleic & 0.12 & 0.14 & 0.26 & 0.06 & 0.26 \\
\hline Pentadecanoic & 0.41 & 0.48 & 0.63 & 0.16 & 0.45 \\
\hline cis-10-Pentadecanoic & 0.06 & 0.10 & 0.15 & 0.04 & 0.36 \\
\hline Palmitic & 11.67 & 14.04 & 15.81 & 3.95 & 0.62 \\
\hline Palmitoleic & 0.56 & 0.51 & 0.76 & 0.21 & 0.78 \\
\hline Heptadecanoic & 0.85 & 0.93 & 1.44 & 0.39 & 0.53 \\
\hline cis-10-Heptadecanoic & 0.24 & 0.66 & 0.33 & 0.14 & 0.85 \\
\hline Stearic & 14.10 & 15.40 & 21.66 & 5.16 & 0.44 \\
\hline Elaidic & 6.88 & 3.23 & 14.80 & 4.64 & 0.25 \\
\hline Oleic & 16.98 & 21.41 & 19.43 & 5.44 & 0.86 \\
\hline Linolelaidic & 0.33 & 0.21 & 0.53 & 0.09 & 0.10 \\
\hline Linoleic & 1.32 & 1.03 & 2.70 & 0.69 & 0.23 \\
\hline$\gamma$-Linolenic & 0.07 & 0.06 & 0.12 & 0.04 & 0.52 \\
\hline Linolenic & 0.87 & 0.58 & 1.43 & 0.47 & 0.31 \\
\hline Saturated & 28.45 & 32.72 & 41.12 & 10.04 & 0.62 \\
\hline Unsaturated (UFA) & 27.43 & 28.21 & 40.51 & 10.14 & 0.50 \\
\hline MUFA & 24.83 & 26.14 & 35.73 & 9.12 & 0.56 \\
\hline PUFA & 2.60 & 2.07 & 4.78 & 1.11 & 0.18 \\
\hline n6 & 1.72 & 1.49 & 3.35 & 0.68 & 0.13 \\
\hline n3 & 0.87 & 0.58 & 1.43 & 0.45 & 0.33 \\
\hline \multicolumn{6}{|l|}{ Fatty acid ratios } \\
\hline SFA/UFA & 1.04 & 1.16 & 1.02 & 0.12 & 0.43 \\
\hline MUFA/PUFA & 9.55 & 12.64 & 7.47 & 1.45 & 0.08 \\
\hline n6/n3 & 1.97 & 2.59 & 2.34 & 0.52 & 0.42 \\
\hline PUFA/SFA & 0.11 & 0.06 & 0.11 & 0.20 & 0.20 \\
\hline
\end{tabular}




\section{Chapter 5 : EXPERIMENT 3}

The effects of delayed introduction of a fat, protein, or a fat enriched protein supplement to continuous culture on fermentation, nutrient digestibility, and fatty acid profile of effluent digesta.

\subsection{ABSTRACT}

The primary objective of this experiment was to investigate the impact of delayed supplementation with fat, protein or a fat and protein mixture, on diurnal changes in fermentative digestion, forage digestibility and effluent digesta fatty acid composition in continuous culture fermenters. Using 8, single-flow, continuous culture fermenters, 3 experimental supplements were tested across 3 experimental runs $(9 \mathrm{~d})$ at 3 supplementation times. In the first, second and third experimental runs, soybean oil (3\% daily DM), soybean meal, (7\% daily DM), and soybean oil with soybean meal (3 and 7\% daily DM) were supplemented to the fermenters at either; 0600 $(\mathrm{AM}), 1800(\mathrm{PM})$, or in evenly divided doses at both times $(\mathrm{AP})$, or not at all (control $=\mathrm{C})$. Within each experimental run, treatments (i.e. time of supplementation) were allocated in a completely randomized design to fermenters with 2 replicates for each time. There were not significant treatment by time interaction effects observed for diurnal TVFA $(\mathrm{P}=0.14)$ but significant treatment by time interaction effects for diurnal $\mathrm{pH}(\mathrm{P}=0.05)$ and $\mathrm{NH}_{3}-\mathrm{N}$ concentration $(\mathrm{P}=0.01)$ were observed when soybean oil or soybean oil enriched soybean meal was supplemented in the AM. Neither significant main factor interactions nor treatment (time of supplementation; AM, AP, PM, C) effects on nutrient digestibility and volatile fatty acid concentrations were observed $(\mathrm{P}>0.05)$. However, significant effects of experimental supplements on nutrient digestibility and volatile fatty acid concentrations were observed $(\mathrm{P}<$ 0.05). At the time of submission of this report data on the effluent content of fatty acids was not 
available. Therefore, in this study, delayed fat supplementation did not significantly alter postprandial fermentation, or compromise fermentative digestion and nutrient digestibility.

\subsection{INTRODUCTION}

A desired objective of ruminant nutritionists has been to alter fatty acid composition of ruminant muscle and adipose tissue and thus alter the nutritional value of ruminant food products (Bolte et al., 2002). Researchers aim to effectively reduce the saturated fatty acid to unsaturated fatty acid (SFA: UFA) ratio of ruminant meats (Woods, et al., 1999). In this regard, optimal escape of the ingested polyunsaturated fatty acids from ruminal biohydrogenation is necessary. Factors altering ruminal fermentation and the microbial population dynamics also regulate the rate and extent of ruminal biohydrogenation of unsaturated fatty acids (Harfoot and Hazelwood, 1997, Kucuk et al., 2001 and Qiu et al., 2004) and thus should be considered in any attempt to improve ruminant meat quality by feeding fat. One such factor is diurnal ruminal $\mathrm{pH}$, which is itself dependent upon ruminal metabolite concentrations. Ruminal metabolite concentrations are affected by several factors including fermentative digestion, ruminal passage rates and dietary forage to concentrate ratio (Kucuk et al., 2001). Therefore supplementation strategy and diurnal variation in intake of ruminants, determine diurnal variation of ruminal metabolite concentrations and $\mathrm{pH}$.

In experiment 1 reported in this dissertation, an interaction between time of fat enriched protein meal supplementation and time of sampling after hay was fed was observed for total and individual VFA, rumen $\mathrm{NH}_{3}-\mathrm{N}$ and $\mathrm{pH}$ for all time treatment groups. Interestingly, the bihourly $\mathrm{pH}$ values were most consistent and generally lower in the lambs that were supplemented at a delayed time. Wales et al. (2004) suggested the possibility of enhanced nutrient digestion when feeding strategies minimize diurnal $\mathrm{pH}$ variation at low ruminal $\mathrm{pH}$. Indeed, in our previous 
study, numerically greater ruminal liquid passage rate and fecal passage rate together with significantly slower ruminal solid passage rate $(\mathrm{P}=0.04)$ suggested enhanced rumen digestibility for lambs that were supplemented at a delayed time.

These observed effects of supplementation strategy on diurnal variation of $\mathrm{pH}$, VFA and $\mathrm{NH}_{3}-\mathrm{N}$ concentrations and rumen kinetics, suggest that rumen microbial populations were also affected. Fluctuations in diurnal rumen metabolites, and $\mathrm{pH}$ affect both microbial population, and ruminal biohydrogenation (Wales et al. 2004), and the extent of ruminal biohydrogenation affects the fatty acid profile of meat. As such the assessment of our fat supplementation strategies used in experiment 1 should have also investigated the effects on ruminal biohydrogenation and fatty acid composition of ruminal or duodenal digesta. Plausibly, delayed feeding of a fat, protein or fat enriched protein supplement might alter diurnal fermentative digestion, ruminal metabolite concentrations and $\mathrm{pH}$, as well as biohydrogenation of ingested fats. Hence, the primary objective of this experiment was to investigate the impact of delayed supplementation with fat, protein or fat and protein, on diurnal changes in fermentative digestion, forage digestibility and effluent digesta fatty acid composition in continuous culture fermenters.

\subsection{MATERIALS AND METHODS}

\subsection{Experimental design}

Using 8 single flow, continuous culture fermenters, three experimental supplements were individually tested across three experimental runs ( $9 \mathrm{~d}$ durations) using three supplementation time strategies in each experimental run. Each experimental run consisted of a five day adaptation and four day sampling periods. In the first, second and third experimental runs, 48.5, 46.5 , or $45 \mathrm{~g}$ of oven dried $\left(50^{\circ} \mathrm{C}\right)$ pasture grass that was harvested in early fall (Table 2$)$ 
representing 97, 93 and $90 \%$ of daily feed (DMI) were added to each fermenter in five unequal meals per day of $30.33,18.67,19.33,10$, and $21.67 \%$ of daily allowance at $0600,1000,1300$, 1600 and 1800, respectively. Control fermenters were fed $50 \mathrm{~g}$ of grass appropriated in the same percentages with the same time schedules as supplemented treatment fermenters (Table 3). In the first, second and third experimental runs, soybean oil (3\% daily DM), soybean meal, (7\% daily DM), and soybean oil with soybean meal (3 and 7\% daily DM) were supplemented to the fermenters at either; 0600 (AM), 1800 (PM), or in evenly divided doses at both times (AP), or not at all $($ control $=\mathrm{C})$. Within each experimental run, treatments (i.e. time of supplementation) were allocated in a completely randomized design to fermenters with 2 replicates for each time and control treatment. This feeding regimen (Table 1) mimics one that was previously utilized to investigate the effects of time of high- energy supplementation to forage fed continuous culture fermenters (unpublished study) which was based on the diurnal variation in intake observed in grazing ruminants that were supplemented with protein (Gekara, et al., 2005).

\subsection{Continuous culture system}

The single flow continuous culture system used in this study was similar to that described by Meng et al., (1999), with the following modifications: the average working volume was $1505.15 \mathrm{ml}$ and liquid dilution rate was maintained at $8.0 \% / \mathrm{h}$ by the continuous infusion of a buffer solution (Weller and Pilgrim, 1974). Agitation was set at 180 rpm, and fermenter temperature was maintained at $39^{\circ} \mathrm{C}$. The fermenters were continually purged with $\mathrm{CO}_{2}$ to maintain anaerobiosis. Rumen inoculums were obtained from nonlactating, ruminally fistulated Holstein cows that were fed a forage rich diet. Rumen contents were squeezed through cheese cloth to obtain $6 \mathrm{~L}$ of rumen fluid and $40 \mathrm{~g}$ of solid digesta which was then transported to the 
laboratory in insulated containers. The rumen fluid was pooled and slowly mixed for $30 \mathrm{~s}$ in a 4$\mathrm{L}$ rotor blender, prior to inoculation of the fermenters. On d1 approximately $5 \mathrm{~g}$ of the ruminal solid digesta was added to each fermenter to supply particle associated microbes. Temperature and agitation speed was checked at each feeding time. The fermentation $\mathrm{pH}$ was not controlled but was monitored at each feeding time.

\subsection{Sample collection and Analysis}

\section{Diurnal samples}

Effluents from each effluent reservoir was collected at $3 \mathrm{~h}$ intervals over a $24 \mathrm{~h}$ period beginning at 0900 on $\mathrm{d} 6$ of each experimental run. Effluent was squeezed through two layers of cheese cloth to obtain liquid samples. Four $45 \mathrm{ml}$ samples were preserved with $0.6 \mathrm{ml}$ of $50 \%$ $\mathrm{H}_{2} \mathrm{SO}_{4}$ and stored at $-20^{\circ} \mathrm{C}$ until they were analyzed for ammonia- N(AOAC, 1990), and VFA concentration. Individual VFA concentrations were summed and reported as total volatile fatty acid concentration (TVFA) for all treatments and in each experimental run. The $\mathrm{pH}$ of each fermenter was recorded from a $\mathrm{pH}$ meter with an attached probe at the times of effluent collection. Analysis of VFA was performed in accordance with the GLC separation procedure described in the literature (Supelco, 1975). At 0600 on d 6 and after each sample collection, the effluent reservoir was treated with $37 \%$ formaldehyde solution at a rate of $2.5 \%(9 \mathrm{ml})$ of anticipated effluent volume to prevent microbial fermentation in the reservoir. The effluent reservoirs were stored in ice cooled water throughout the day on $\mathrm{d} 6$ to end of $\mathrm{d} 9$. 


\section{Daily Samples}

On each day from day 7 to 9 , effluent reservoirs were treated with $72 \mathrm{ml}$ formaldehyde at 0600 and at the end of the day $(0600$ on $\mathrm{d} 8,9,10) 500 \mathrm{ml}$ of digesta effluents were collected and stored at $4{ }^{\circ} \mathrm{C}$. The $500 \mathrm{ml}$ samples were bulked across the three sampling days for each fermenter, and a $500 \mathrm{ml}$ sub-sample was collected from this to determine DM content. Effluent DM was determined by centrifuging a 40-g sample of effluent at 30,000 x g for $45 \mathrm{~min}$. The supernatant was discarded, and the particulate matter was dried at $100^{\circ} \mathrm{C}$ for $24 \mathrm{~h}$ and reweighed. The remaining (1L) effluent that was collected at the end of day 9 was freeze dried, ground through a 1-mm screen and analyzed for NDF, ADF, CP, EE, and fatty acid composition. Nutrient digestibility was also calculated. The DM of pasture grass and soybean meal was determined by oven drying at $100^{\circ} \mathrm{C}$ for $24 \mathrm{~h}$. Pasture grass and soybean meal were further analyzed for NDF ADF and ADL (Van Soest et al., 1991), ash, nitrogen, ether extract (AOAC, 1990), and fatty acid composition. Lipids were extracted by the methods of Bligh and Dyer (1959) and fatty acids were esterified in a $4 \% \mathrm{H}_{2} \mathrm{SO}_{4}$ anhydrous methanol solution (Fritshe and Johnston 1990). The method of Kamireddy (2004) was used to identify and quantify fatty acid methyl ester (FAME). Rumen effluent digesta fatty acid content was reported as mg of fatty acids detected in a $0.1 \mathrm{~g}$ sample of effluent digesta, grass and soybean meal. A $250 \mathrm{ml}$ sample of the mineral buffer solution was taken on each collection day from d6 to $\mathrm{d} 9$ combined and used for DM and ash determination.

\subsection{Data Analysis}

Nutrient digestibility, average individual VFAs and TVFA, and fatty acid data were analyzed as a generalized completely randomized block design with two fixed factors using the 
procedures of SAS (SAS, Institute, Cary, NC). Experimental run (1, 2, and 3, respectively) was the blocking factor and treatment (time of supplementation; AM, AP, PM, and C) was the other factor. Results are reported as means and SE values. Statistical analysis of VFA, $\mathrm{NH}_{3}-\mathrm{N}$ concentrations and $\mathrm{pH}$ were done using repeated measures covariance model with treatments (time of feeding supplement), and time (after forage was first fed) as main factors.

\subsection{RESULTS AND DISCUSSION}

\subsection{Diurnal fermentation, metabolites concentrations, and $\mathrm{pH}$}

There were not significant treatment by time interaction effects observed for diurnal TVFA $(\mathrm{P}=0.14)$ but significant treatment by time interaction effects for diurnal $\mathrm{pH}(\mathrm{P}=0.05)$ and $\mathrm{NH}_{3}-\mathrm{N}$ concentration $(\mathrm{P}=0.01)$ were observed. The treatment by time interaction $(\mathrm{P}<0.05)$ was observed on diurnal $\mathrm{pH}$ and $\mathrm{NH}_{3}-\mathrm{N}$ concentrations when fermenters were supplemented with the soybean oil or the soybean oil and soybean meal mixture in the AM (Fig. 1 and 3). These data indicates that treatment effects on diurnal fermentation patterns were evident and may be linked to diurnal protein metabolism as have been suggested previously (Judkins et al. 1990; Owens, and Zinn. 1988).

Fermentation profiles observed in this study might be explained by the suggestions of Leedle et al., (1982), wherein the progressive fermentation of forage fed to the fermenters proceeds on a time basis and dictates diurnal variation of the microbial population. More rapidly fermented carbohydrates are fermented prior to less digestible fractions. In the system employed in this experiment the feeding strategy continually introduces fresh forage and thus fresh supply 
of rapidly fermentable carbohydrate is also continuously introduced into the system. The newly supplied rapidly fermentable carbohydrates might be introduced into a system where previously supplied rapidly fermentable carbohydrates are depleted but slower degrading carbohydrates have commenced degradation. The effect of low levels of supplement on microbial digestion in this system should therefore be minimal in the first 12 to $15 \mathrm{~h}$ post initiation of feeding as was observed (Fig. 1 and 2). In the latter period of the day when rapidly fermentable carbohydrates have been depleted and resupplies have ceased then the effects of supplement on the microbial population and presumably fermentation would become more visible. Indeed, microbial species composition and presumably digestion might be affected by feed intake level (Hungate, 1975), frequency of feeding (Dehority, 2003), the postprandial time at which the rumen was sampled (Bryant and Robinson, 1968) or in-vitro incubation time (Dehority, 2003).

Reductions in number of viable microbes prior to $16 \mathrm{~h}$ after the commencement of feeding (Leedle et. al., 1982) reduce microbial digestion. The extent of reduction in viable microbial population and activity within the in-vitro fermenter in this study could be influenced by the time of introduction of supplements. The decline in $\mathrm{NH}_{3}-\mathrm{N}$ concentration in $\mathrm{C}$ beginning at $15 \mathrm{~h}$ contrast with declines observed in AM treatments at $18 \mathrm{~h}$ when either soybean oil or soybean oil and soybean meal mixture supplements were fed (Fig. 1). The effects of variations in diurnal profile of $\mathrm{NH}_{3}-\mathrm{N}$ on microbial population dynamics and digestion might be reflected in corresponding variations of TVFA profile. The latter suggestion is supported mainly by the rapid decline in TVFA concentration between the $15^{\text {th }}$ and $18^{\text {th }} \mathrm{h}$ in the AM treatment when either the soybean oil or soybean oil and soybean meal mixture supplements were fed (Fig. 2). 
Ultimately, the microbial population dynamics are linked to the supply of $\mathrm{NH}_{3}-\mathrm{N}$. The main sources of this $\mathrm{NH}_{3}-\mathrm{N}$ are the forage and artificial buffer but dead microbes upon degradation would also contribute to $\mathrm{NH}_{3}-\mathrm{N}$ concentrations. The extent to which the latter contribution affects total $\mathrm{NH}_{3}-\mathrm{N}$ concentrations is most likely variable, and might explain some of the variation in the effects of supplemental fat on ruminal $\mathrm{NH}_{3}-\mathrm{N}$ concentrations previously reported (Jenkins, 1990; Jenkins and Fotouhi 1990; Oldick and Firkins, 2000). Perceivably, the supply of microbial nitrogen as influenced by; toxic effects of added fat (Hartfoot and Hazelwood, 1988), by enhancing effects of supplemental protein, or a combination of negative and positive effects of fat enriched protein on microbes is important in this system for maintenance of $\mathrm{NH}_{3}-\mathrm{N}$ concentrations and microbial populations. Fat supplementation may increase turnover rates, protein supplementation increases the size of microbe populations, and fat enriched protein achieves a combination of increase turn over and population size. The changes in microbial population in turn affect diurnal digestive patterns, and TVFA concentrations. Fluctuations in TVFA and $\mathrm{NH}_{3}-\mathrm{N}$ are in turn reflected in $\mathrm{pH}$ changes over time as indicated when soybean oil or when the soybean meal and soybean oil mixture was supplemented in the AM (Fig. 3). Thus generating the treatment by time interaction effects $(\mathrm{P}=$ 0.05) on diurnal $\mathrm{pH}$ that were observed.

\subsection{Nutrient digestibility and volatile fatty acid concentrations}

Neither significant main factor interactions nor treatment (time of supplementation; AM, AP, PM, C) effects on nutrient digestibility and volatile fatty acid concentrations were observed (P $>0.05$, Table 4 and 6). However, significant effects of experimental supplements on nutrient digestibility and volatile fatty acid concentrations were observed and reported $(\mathrm{P}<0.05$, Table 5 
and 7). Except for dry matter, organic matter and crude protein, lowest nutrient digestibility $(\mathrm{P}<$ 0.05 ) was observed when soybean meal without soybean oil was added to fermenters. Lower nutrient digestibility occurred as supplemental protein promoted the rate of fermentation and formation of floating solid digesta mass in the fermenter. As the size of this mass increased the rate of loss of undigested finely ground forage from the fermenters was probably increased. This suggests that within the in-vitro fermenter diurnal fermentation patterns differed but at the end of the day digestion was equally effective across most of the treatments. This might be expected with this feeding strategy which utilized only low levels of fat (Palmquist and Jenkins, 1980; Kucuk et al., 2004), protein or fat enriched protein supplements. In addition the refined nature of the feed that were fed to fermenters, especially the soybean meal, probably enhanced overall nutrient digestibility. The latter explains the effects of experimental supplement on butyrate and isoacids but not acetate, propionate or TVFA concentrations (Table 7). Deleterious effects of soybean oil treatment on microbes (Harfoot and Hazelwood, 1988) and digestion were probably counteracted by enhancing effects of synchronous soybean meal protein supplementation (Judkins et al., 1991). Indeed, the decline in TVFA concentrations at 15 to $18 \mathrm{~h}$ observed in the AM treatment when soybean oil was fed (Fig. 1 and 2) was present but not as prevalent in the AM treatment when soybean oil and soybean meal mixture was fed.

\subsection{Fatty acid composition}

At the time of preparing this report the fatty acid composition of effluent digesta was not available. 


\section{CONCLUSION}

Therefore, in this study, delayed fat supplementation did not significantly alter postprandial fermentation, or compromise fermentative digestion and nutrient digestibility. 
Table 1. Feeding regime utilized in experiment 3.

\begin{tabular}{|c|c|c|c|c|c|c|}
\hline & \multicolumn{6}{|c|}{ Run } \\
\hline \multirow{3}{*}{ Treatments } & \multicolumn{2}{|c|}{1} & \multicolumn{2}{|c|}{2} & \multicolumn{2}{|c|}{3} \\
\hline & & \multirow[b]{2}{*}{ Forage $(\mathrm{g})$} & & & Soybean & \\
\hline & $\begin{array}{l}\text { Soybean } \\
\text { oil }(\mathrm{g})\end{array}$ & & $\begin{array}{l}\text { Soybean } \\
\text { meal (g) }\end{array}$ & Forage $(\mathrm{g})$ & $\begin{array}{l}\text { oil and } \\
\text { meal (g) }\end{array}$ & Forage $(\mathrm{g})$ \\
\hline Control & 0.00 & 50.00 & 0.00 & 50.00 & 0.00 & 50.00 \\
\hline $\mathrm{AM}$ & 1.50 & 48.50 & 3.50 & 46.50 & 5.00 & 45.00 \\
\hline AP & 1.50 & 48.50 & 3.50 & 46.50 & 5.00 & 45.00 \\
\hline PM & 1.50 & 48.50 & 3.50 & 46.50 & 5.00 & 45.00 \\
\hline \multicolumn{7}{|c|}{ AM Soybean oil (Run1), soybean meal (Run 2) or soybean oil enriched soybean meal (Run 3) supplement offered at 0600, h } \\
\hline \multirow{2}{*}{\multicolumn{7}{|c|}{$\begin{array}{l}\text { AP Soybean oil (Run1), soybean meal (Run 2) or soybean oil enriched soybean meal (Run 3) supplement offered at } 0600 \text { and } \\
1800, \mathrm{~h}\end{array}$}} \\
\hline & & & & & & \\
\hline \multicolumn{7}{|c|}{ PM Soybean oil (Run1), soybean meal (Run 2) or soybean oil enriched soybean meal (Run 3) supplement offered at 1800, h } \\
\hline \multicolumn{7}{|c|}{ Feed } \\
\hline \multicolumn{2}{|l|}{ Nutrient (\%) } & \multirow{2}{*}{\multicolumn{2}{|c|}{ Forage }} & \multicolumn{3}{|c|}{ Soybean meal } \\
\hline \multicolumn{2}{|l|}{ DM } & & & \multicolumn{2}{|c|}{94.43} & \\
\hline \multicolumn{2}{|l|}{$\mathrm{ASH}$} & \multicolumn{2}{|l|}{9.50} & \multicolumn{2}{|c|}{6.07} & \\
\hline \multicolumn{2}{|l|}{$\mathrm{OM}$} & \multicolumn{2}{|l|}{90.50} & \multicolumn{2}{|c|}{93.93} & \\
\hline \multicolumn{2}{|l|}{$\mathrm{CP}$} & \multicolumn{2}{|l|}{17.72} & \multicolumn{2}{|c|}{42.58} & \\
\hline \multicolumn{2}{|l|}{ NDF } & \multicolumn{2}{|l|}{56.83} & \multicolumn{2}{|c|}{4.66} & \\
\hline \multicolumn{2}{|l|}{$\mathrm{ADF}$} & \multicolumn{2}{|l|}{26.69} & 1.6 & & \\
\hline ADL & & 2.90 & & 0.0 & & \\
\hline Ether Extract & & 2.81 & & 6.9 & & \\
\hline
\end{tabular}

Table 3 . Feeding schedule utilized in experiment 3.

\begin{tabular}{l|l|lclc}
\hline \multicolumn{5}{c}{ Forage, $\mathrm{g}$} \\
\hline Time, $\mathrm{h}^{1}$ & $\begin{array}{l}\text { Percent } \\
\text { meal }^{2}, \%\end{array}$ & Run $1^{3}$ & Run $2^{3}$ & Run $3^{3}$ & $1,2 \& 3^{4}$ \\
\hline 0600 & 30.33 & 14.71 & 14.10 & 13.65 & 15.17 \\
1000 & 18.67 & 9.05 & 8.68 & 8.40 & 9.34 \\
1300 & 19.33 & 9.38 & 8.99 & 8.70 & 9.67 \\
1600 & 10.00 & 4.85 & 4.65 & 4.50 & 5.00 \\
1800 & 21.67 & 10.51 & 10.08 & 9.75 & 10.84 \\
\hline
\end{tabular}

${ }^{\mathrm{I}}$ Times at which forage was fed to fermenters

${ }^{2}$ The percent of total daily forage fed at each time

${ }^{3}$ Quantity of forage (g) offered to supplemented fermenters in run 1, 2, or 3

${ }^{4}$ Quantity of forage (g) offered to control fermenters in runs 1, 2, and 3 
Table 4. Effects of treatments on nutrient digestibility in experiment 3

\begin{tabular}{l|llllll}
\hline \multicolumn{7}{c}{ Treatments } \\
\hline Variables (\%) & Control & AM & AP & PM & \pm SE & P-value \\
\hline DM & 85.17 & 82.50 & 83.00 & 81.50 & 2.15 & 0.68 \\
OM & 87.33 & 85.00 & 84.50 & 84.00 & 1.95 & 0.64 \\
CP & 84.83 & 82.00 & 82.50 & 81.83 & 2.24 & 0.76 \\
NDF & 88.67 & 87.00 & 86.50 & 86.67 & 2.00 & 0.86 \\
ADF & 87.83 & 86.00 & 85.67 & 85.33 & 2.10 & 0.83 \\
ADL & 76.50 & 74.67 & 75.50 & 73.00 & 3.70 & 0.92 \\
Ether Extract & 77.33 & 73.00 & 73.83 & 72.33 & 4.46 & 0.86 \\
\hline
\end{tabular}

Supplement offered at 0600, h (AM), 1800, h (PM) or at both times (AP) or not at all (control)

Table 5. Effects of experimental supplements on nutrient digestibility in experiment 3

Supplements

\begin{tabular}{l|lllll}
\hline Variables (\%) & Soybean oil & $\begin{array}{l}\text { Soybean } \\
\text { meal }\end{array}$ & $\begin{array}{l}\text { Soybean oil } \\
\text { enriched } \\
\text { soybean } \\
\text { meal }\end{array}$ & PE & \\
\hline DM & $86.25^{\mathrm{a}}$ & $79.50^{\mathrm{b}}$ & $83.37^{\mathrm{a}}$ & 1.86 & 0.02 \\
$\mathrm{OM}$ & $88.88^{\mathrm{a}}$ & $81.25^{\mathrm{b}}$ & $85.50^{\mathrm{a}}$ & 1.69 & 0.01 \\
$\mathrm{CP}$ & 85.50 & 80.25 & 82.62 & 1.94 & 0.20 \\
$\mathrm{NDF}$ & $91.63^{\mathrm{a}}$ & $82.38^{\mathrm{b}}$ & $87.63^{\mathrm{a}}$ & 1.73 & 0.01 \\
$\mathrm{ADF}$ & $90.62^{\mathrm{a}}$ & $81.00^{\mathrm{b}}$ & $87.00^{\mathrm{a}}$ & 1.82 & 0.01 \\
$\mathrm{ADL}$ & $85.50^{\mathrm{a}}$ & $64.50^{\mathrm{b}}$ & $74.75^{\mathrm{c}}$ & 3.21 & 0.01 \\
Ether Extract & $81.88^{\mathrm{a}}$ & $61.50^{\mathrm{b}}$ & $79.00^{\mathrm{a}}$ & 3.86 & 0.01 \\
\hline a,b,c Within a row means without a common superscript letter differ $(\mathrm{P}<0.05)$ & & \\
\hline
\end{tabular}

${ }^{\mathrm{b}, \mathrm{c}}$ Within a row means without a common superscript letter differ $(\mathrm{P}<0.05)$ 
Table 6 Effects of treatment on volatile fatty acid concentrations

\begin{tabular}{l|llllll}
\hline \multicolumn{7}{c}{ Treatments } \\
\hline Variables & Control & AM & AP & PM & \pm SE & P-value \\
\hline Acetate $(\mathrm{mM} / \mathrm{L})$ & 27.86 & 26.13 & 32.02 & 29.50 & 2.17 & 0.31 \\
Propionate $(\mathrm{mM} / \mathrm{L})$ & 7.03 & 6.89 & 8.52 & 7.53 & 0.59 & 0.26 \\
Isobutyrate $(\mathrm{mM} / \mathrm{L})$ & 0.33 & 0.35 & 0.43 & 0.38 & 0.03 & 0.23 \\
Butyrate $(\mathrm{mM} / \mathrm{L})$ & 3.23 & 3.26 & 4.23 & 3.64 & 0.29 & 0.09 \\
Isovalerate $(\mathrm{mM} / \mathrm{L})$ & 0.19 & 0.24 & 0.29 & 0.27 & 0.04 & 0.29 \\
Valerate $(\mathrm{mM} / \mathrm{L})$ & 0.62 & 0.63 & 0.83 & 0.73 & 0.07 & 0.19 \\
TVFA $^{1}(\mathrm{mM} / \mathrm{L})$ & 39.25 & 37.56 & 46.20 & 42.03 & 3.07 & 0.26 \\
\hline Supp & & & &
\end{tabular}

Supplement offered at 0600, h (AM), 1800, h (PM) or at both times (AP) or not at all (control)

${ }^{1}$ Total volatile fatty acid (TVFA)

Table 7 Effects of experimental supplements on volatile fatty acid concentrations

\begin{tabular}{|c|c|c|c|c|c|}
\hline \multicolumn{6}{|c|}{ Supplements } \\
\hline Variables & Soybean oil & $\begin{array}{l}\text { Soybean } \\
\text { meal }\end{array}$ & $\begin{array}{l}\text { Soybean } \\
\text { oil } \\
\text { enriched } \\
\text { soybean } \\
\text { meal }\end{array}$ & $\pm \mathrm{SE}$ & P-value \\
\hline Acetate $(\mathrm{mM} / \mathrm{L})$ & 27.43 & 30.72 & 28.48 & 1.88 & 0.47 \\
\hline Propionate $(\mathrm{mM} / \mathrm{L})$ & 6.73 & 8.10 & 7.65 & 0.51 & 0.20 \\
\hline Isobutyrate $(\mathrm{mM} / \mathrm{L})$ & $0.28^{\mathrm{a}}$ & $0.42^{\mathrm{b}}$ & $0.41^{\mathrm{b}}$ & 0.03 & 0.01 \\
\hline Butyrate $(\mathrm{mM} / \mathrm{L})$ & $2.90^{\mathrm{a}}$ & $3.96^{\mathrm{b}}$ & $3.90^{\mathrm{b}}$ & 2.62 & 0.02 \\
\hline Isovalerate $(\mathrm{mM} / \mathrm{L})$ & $0.13^{\mathrm{a}}$ & $0.32^{\mathrm{b}}$ & $0.28^{\mathrm{b}}$ & 0.03 & 0.01 \\
\hline Valerate $(\mathrm{mM} / \mathrm{L})$ & $0.55^{\mathrm{b}}$ & $0.74^{\mathrm{b}}$ & $0.82^{\mathrm{b}}$ & 0.06 & 0.03 \\
\hline TVFA $^{1}(\mathrm{mM} / \mathrm{L})$ & 38.03 & 44.26 & 41.50 & 2.65 & 0.29 \\
\hline
\end{tabular}

${ }^{\mathrm{a}, \mathrm{b}}$ Within a row means without a common superscript letter differ $(\mathrm{P}<0.05)$

${ }^{1}$ Total volatile fatty acid (TVFA) 


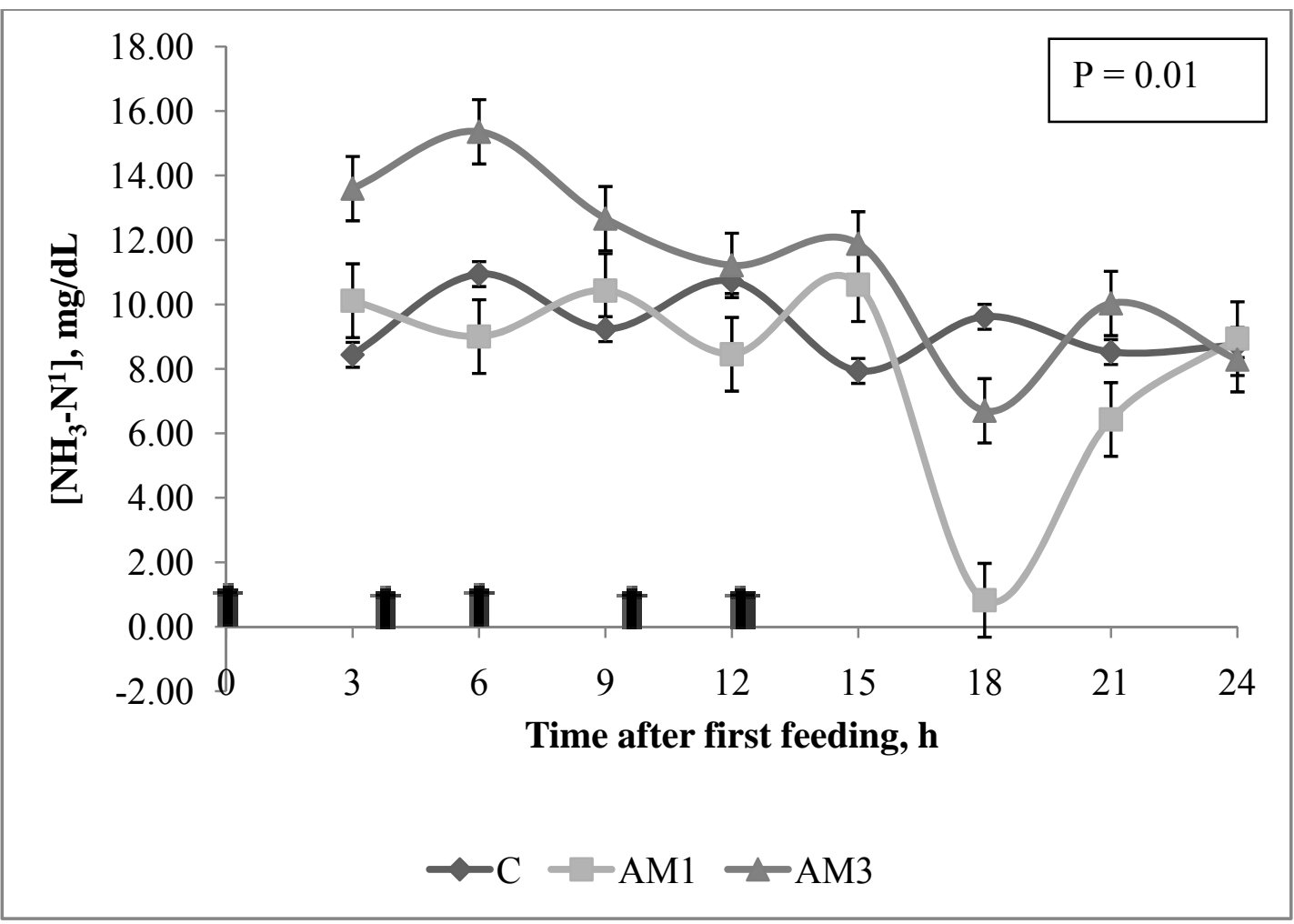

Figure 1. Effects of time of supplementation of soybean oil or soybean oil mixed with soybean meal on fermenter ammonia nitrogen $\left(\mathrm{NH}_{3}-\mathrm{N}^{1}\right)$ concentrations

\footnotetext{
${ }^{1}$ Ammonia nitrogen

Indicates the times at which forage was fed

$\mathrm{C}=$ control

AM1. Soybean oil supplemented at $0600 \mathrm{~h}$

AM3. Soybean oil and soybean meal mixture supplemented at $0600 \mathrm{~h}$

Treatment by time interaction effect is significant if $\mathrm{P} \leq 0.05$
} 


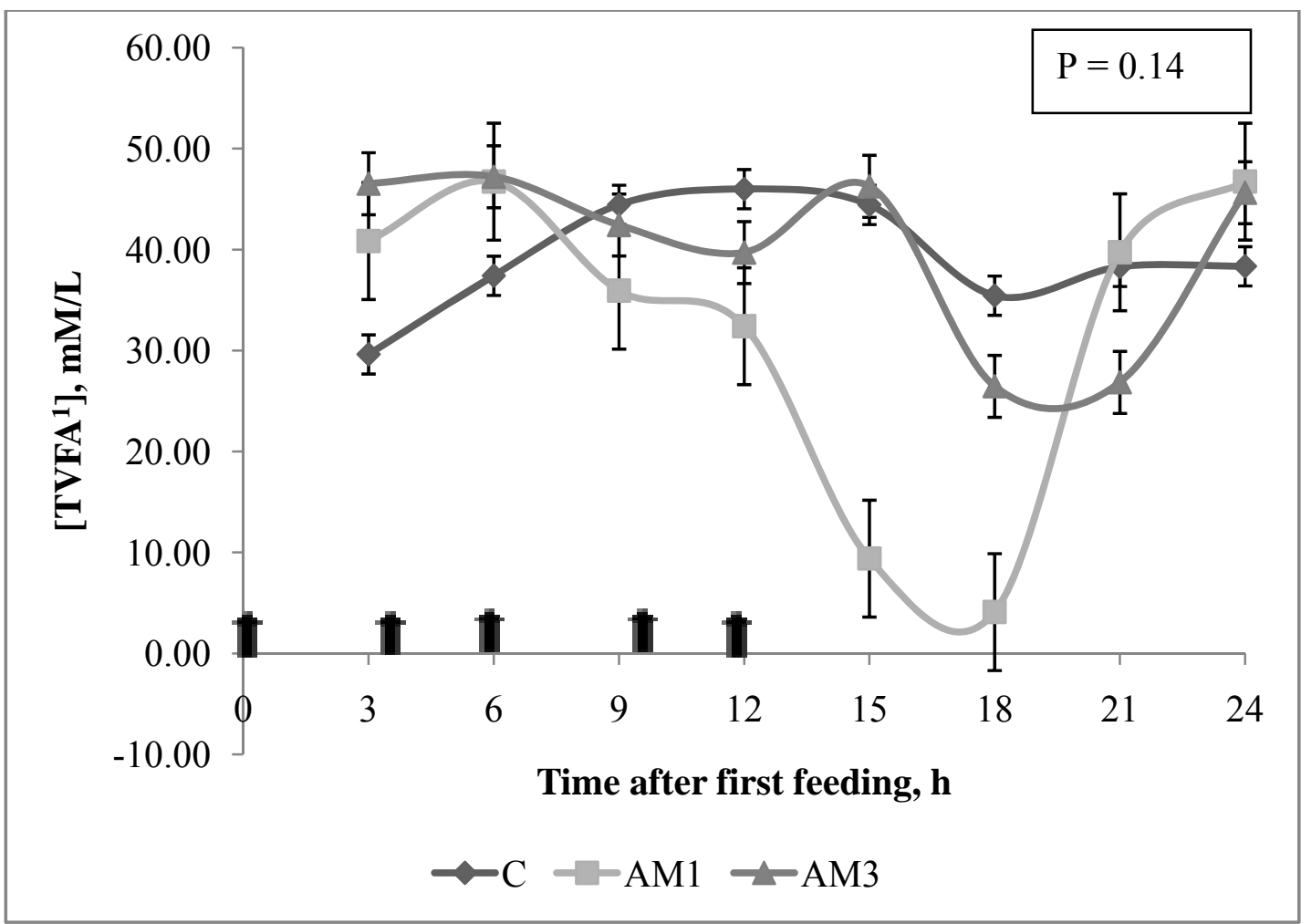

Figure 2. Effects of time of supplementation of soybean oil or soybean oil mixed with soybean meal on fermenter TVFA ${ }^{1}$ concentrations

${ }^{1}$ Total volatile fatty acid

Indicates the times at which forage was fed

$\mathrm{C}=$ control

AM1. Soybean oil supplemented at $0600 \mathrm{~h}$

AM3. Soybean oil and soybean meal mixture supplemented at $0600 \mathrm{~h}$

Treatment by time interaction effect is significant if $\mathrm{P} \leq 0.05$ 


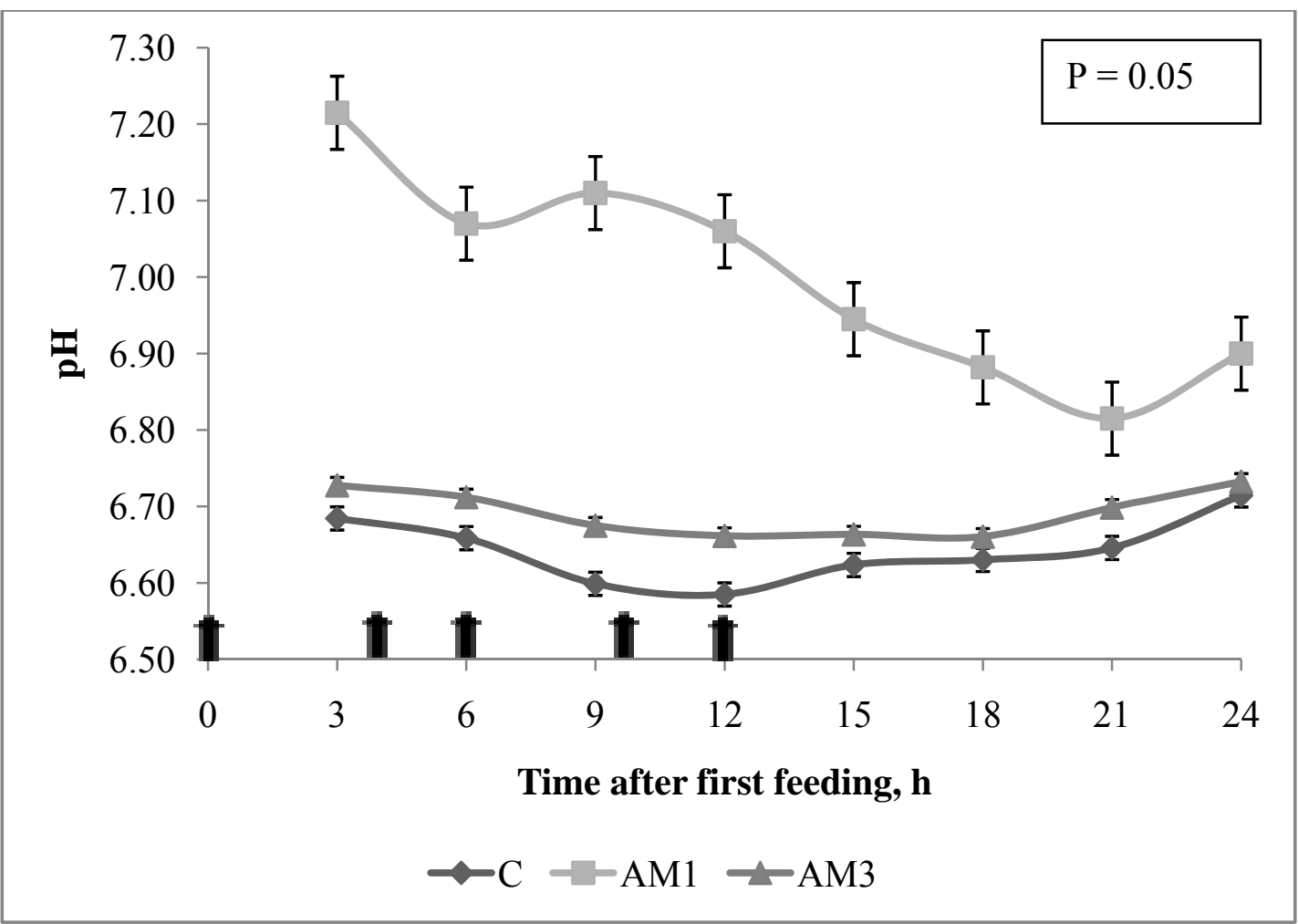

Figure 3. Effects of time of supplementation of soybean oil or soybean oil mixed with soybean meal on fermenter $\mathrm{pH}$

Indicates the times at which forage was fed

$\mathrm{C}=$ control

AM1. Soybean oil supplemented at $0600 \mathrm{~h}$

AM3. Soybean oil and soybean meal mixture supplemented at $0600 \mathrm{~h}$

Treatment by time interaction effect is significant if $\mathrm{P} \leq 0.05$ 


\section{RECOMMENDATIONS}

Producers who wish to utilize low levels of supplemental soybean oil to high forage fed lambs may not be overly concerned about the time at which that supplement is introduced. However delayed supplementation of that fat supplement may avert digestion disturbances while enhancing the fatty acid content of lamb. Synchronous supplementation of protein with fat supplements might also be instrumental in maintaining digestion when fat supplements are used. Presumably, delayed fat supplementation strategies might offer increased benefits for digestion as the level of supplemental fat is increased or alternative fat sources are used to enhance fatty acid quality of lamb. 


\section{Chapter 6 : BIBLIOGRAPHY}

Adams, D.C. 1985. Effect of time of supplementation on performance, forage intake, and grazing behavior of yearling beef steers grazing Russian wild ryegrass in the fall. J. Anim. Sci. 61:10371042.

Allen, C.E. D.C. Beitz, D.A. Cramer, and R.G. Kaufman. 1978. The Biology of Fat in Meat Animals pg 4-6.

Andrae J.G., Hunt C.W., Duckett S.K., Kennington L.R., Feng P., Owens F.N., and Soderlund S. 2000. Effect of high oil corn on growth performance, diet digestibility, and energy content of finishing diets fed to beef cattle. J. Anim. Sci. 78: 2257-2262.

Andrae J.G., Duckett S.K., Hunt C.W., Pritchard G.T., Owens F.N. 2001. Effects of feeding high oil corn to beef steers on carcass characteristics and meat quality. J. Anim. Sci. 79: 582-588.

AOAC. 1990. Official Methods of Analysis. $15^{\text {th }}$ ed. Assoc. Off. Anal. Chem., Arlington, VA.

Argyle, J.L., and R.L. Baldwin. 1989. Effects of amino acids and peptides on rumen microbial growth yields. J. Dairy Sci. 72:2017-2027.

Aurousseau, B., D. Bauchart, X. Faure, A.L. Galot, S. Prache, D. Micol, and A. Priolo. 2007. Indoor fattening of lambs raised on pasture: (1) Influence of stall finishing duration on lipid classes and fatty acids in the longissimus thoracis muscle. Meat Science 76: 241-252. 
Barton, R.K., L.J. Krysl, M.B. Judkins, D.W. Holcombe, J.T. Broesder, S.A. Gunter, and S.W. Beam. 1992. Time of daily supplementation for steers grazing dormant intermediate wheatgrass pasture J. Anim. Sci. 70:547-558.

Bayourthe, C., R. Moncoulon, M. Vernay. 1993. Effect of protein protected fat on ruminal and total nutrient digestibility of sheep diets. J. Anim. Sci. $71: 1026-1031$.

Beever, D.E., and R.C. Siddons. 1986. Digestion and metabolism in grazing ruminants. Pages 479-497 in Control of Digestion and Metabolism in Ruminants. L.P. Milligan, W.L. Grovum and A. Dobson ed. Reston publishing Co., Reston VA.

Benson J.A., Reynolds C.K., Humphries D.J., Rutter S.M., and Beever D.E. 2001a. Effects of abomasal infusion of long chain fatty acids on intake feeding behavior and milk production in dairy cows. J. Dairy Sci. 84:1182-1191.

Benson J.A., and Reynolds C.K. 2001b. Effects of abomasal infusion of long chain fatty acids on splanchnic metabolism of pancreatic and gut hormones in lactating dairy cows. J. Dairy Sci. 84:1488-1500.

Benson J.A., Reynolds C.K., Aikman P.C., Lupoli B., and Beever D.E. 2002. Effects of abomasal vegetable oil infusion on splanchnic nutrient metabolism in lactating dairy cows. J. Dairy Sci. 85:1804-1814. 
Bligh EG, Dyer WJ. 1959. A rapid method of total lipid extraction and purification. Can J Biochem Physiol. 37:911-917.

Boles, J.A., R.W. Kott, P.G. Hatfield, J.W. Bergman, C.R. Flynn. 2005. Supplemental safflower oil affects the fatty acid profile, including conjugated linoleic acid, of lamb. J.Anim. Sci. $83: 2175-2181$.

Bolte, M.R., B.W. Hess, W. J. Means, G.E. Moss, and D.C. Rule. 2002. Feeding lambs high oleate safflower seeds differentially influences carcass fatty acid composition. J. Anim. Sci. 609616.

Bryant, M.P., and I. M. Robinson.1968. Effects of diet, time after feeding, and position sampled on numbers of viable bacteria in the bovine rumen. J. Dairy Sci. 51:1950-1955.

Canale, C. J., P.L. Burgess, L.D. Muller, and G.A. Varga. 1990. Calcium salts of fatty acids in diets that differ in neutral detergent fiber : Effect on lactation performance and nutrient digestibility. J. Dairy Sci. 73: 1031-1038.

Canton, J.S. and D.V. Dhuyvetter. 1997. Influence of energy supplementation on grazing ruminants: Requirements and responses. J. Anim. Sci. 75:533-542. 
Chang, J.H.P., D.K. Lunt, and S.B. Smith. 1992. Fatty acid composition and fatty acid elongase and stearoyl -CoA desaturase activity in tissues of steers fed high oleate sunflower seed. J. Nutr. 122:2074-2080.

Chelikani P.K., Glimm D.R., Keisler D.H., and Kennelly J.J. 2004. Effects of feeding or abomasal infusion of canola oil in Holstein cows. 2 Gene expression and plasma concentrations of cholecystokinin and leptin. J. Dairy Res. $71288-296$.

Choi B.R., and D. L. Palmquist. 1996. High fat diets increase plasma cholecystokinin and pancreatic polypeptide, and decrease plasma insulin and feed intake in lactating cows. J. Nutr. 126:2913-2919.

Choi B.-R., D.L. Palmquist, M.S. Allen. 2000. Cholecystokinin mediates depression of feed intake in dairy cattle fed high fat diets. Domestic Animal Endocrinology 19, 159-175.

Cooper S. L., L. A. Sinclair, R. G. Wilkinson, K. G. Hallett, M. Enser, and J. D. Wood. 2004. Manipulation of the n-3 polyunsaturated fatty acid content of muscle and adipose tissue in lambs. J. Anim. Sci. 82:1461-1470.

Cuitun, L. L., W. H. Hale, B. Theurer, F. D. Dryden, and J. A. Marchello. 1975. Protein protected fat for ruminants. I. Digestion and performance in fattening steers. J. Anim. Sci. 40:691-696. 
Daniel Z. C. T. R., R. J. Wynn, A. M. Salter, and P. J. Buttery. 2004. Differing effects of forage and concentrate diets on the oleic acid and conjugated linoleic acid content of sheep tissues: The role of stearoyl- CoA desaturase. J. Anim. Sci. 82:747-758.

Dehority, B. A. 2003. Rumen microbiology. Nottingham University Press. Nottingham U.K pg 265-278.

Demirel G., A. M. Wachira, L. A. Sinclair, R. G. Wilkinson, J. D. Wood and M. Enser. 2004. Effects of dietary n-3 polyunsaturated fatty acids, breed and dietary vitamin E on the fatty acids of lamb muscle, liver and adipose tissue. Br. J. Ntr., 91, 551-565.

Doreau M., Y. Chilliard. 1997a. Effects of ruminal or postruminal fish oil supplementation on intake and digestion in dairy cows. Reprod. Nutr. Dev. 37,113-124.

Doreau M., and Chilliard Y. 1997b. Digestion and metabolism of dietary fat in farm animals. Br. J. Nutr. 78, Suppl. 1, S15-S35.

Dove, H., J.A. Milne, A.M. Sibbald, C.S. Lamb, and H.A. McCormack. 1988. Circadian variation in abomasal digesta flow in grazing ewes during lactation. Br. J. Nutr. 60:653-668.

Felton, E.E.D. 2001. Feeding soybeans as a source of protein and fat in grow finish rations for feedlot steers. Ph. D. Diss. University of Missouri, Columbia. 
Felton, E.E.D., and M.S. Kerley. 2004a. Performance and carcass quality of steers fed whole raw soybeans at increasing inclusion levels. J. Anim. Sci. 82:725-732.

Felton, E.E.D., and M.S. Kerley. 2004b. Performance and carcass quality of steers fed different sources of dietary fat. J. Anim. Sci. 82:1794-1805.

Fritshe KL, Johnston PU. 1990. Effect of dietary-linolenic acid on growth, metastasis, fatty acid profile and prostaglandin production of two murine mammory adenocarcinomas. J Nutr 120: 1601-1609.

Gekara, O.J., E.C. Prigge, W.B. Bryan, M. Schettini, E.L. Nestor, and E.C. Towsend. 2001. Influence of pasture sward height and concentrate supplementation on intake, digestibility, and grazing time of lactating beef cows. J. Anim. Sci. 79:745-752.

Gekara, O.J., E.C. Prigge, W.B. Bryan, E.L. Nestor and G. Seidel. 2005. Influence of sward height, daily timing of concentrate supplementation, and restricted time for grazing on forage utilization by lactating beef cows J. Anim. Sci. 83:1435-1444.

Grummer, R.R. 1988. Influence of prilled fat and calcium salts of palm oil fatty acids on ruminal fermentation and nutrient digestibility. J. Dairy Sci. 71: 117-123. 
Gulati, S.K., J.R. Ashes, and T.W. Scott. 1999. Hydrogenation of eicosapentaenoic and docosahexaenoic acids and their incorporation into milk fat. Animal Feed Science and Technology 79, 57-64.

Gurr, M.I., J.L. Harwood, K.N. Frayn. 2002. Lipid biochemistry. An introduction. $5^{\text {th }}$ Edition. Blackwell Science Ltd. UK.

Harfoot, C.G., and G. P. Hazelwood, 1988. Lipid metabolism in the rumen. Page 258 in The Rumen Microbial Ecosystem. P.N. Hobson and C.S Stewart, eds. Chapman and Hall/Elselvier New York, NY.

Harfoot, C.G., and G. P. Hazelwood. 1997. Lipid metabolism in the rumen. Pages 382-426 in The Rumen Microbial Ecosystem. P.N. Hobson and C.S Stewart, eds. Chapman and Hall New York, NY.

Harvantine K.J. and Allen M.S. 2006a. Effects of fatty acid supplements on milk yield and energy balance in lactating dairy cows J. Dairy Sci. 89:1081-1091.

Harvantine K.J. and Allen M.S. 2006b. Effects of fatty acid supplements on ruminal and total tract nutrient digestion in lactating dairy cows J. Dairy Sci. 89:1092-1103.

Harvantine K.J. and Allen M.S. 2006c. Effects of fatty acid supplements on feed intake and feeding and chewing behavior of lactating dairy cows J. Dairy Sci. 89: 1104-1112. 
Hungate R.E., 1975. The Rumen Microbial Ecosystem. Annual Review of Ecology and Systematics, Vol. 6, pp. 39-66.

Ikwuegbu O.A. and Sutton J.D. 1982. The effect of varying the amount of linseed oil supplementation on rumen metabolism in sheep. Br. J. Nutr. 48 (2) : 365-375.

Jenkins, T.C., and D.L. Palmquist. 1984. Effects of fatty acids and calcium soaps on rumen and total nutrient digestibility of dairy rations. J.Dairy.Sci. 67:978-986.

Jenkins, T.C., and N. Fotouhi. 1990. Effects of lecithin and corn oil on site of digestion, ruminal fermentation and microbial protein synthesis in sheep. J.Anim.Sci. 68:460-466.

Jenkins, T.C. 1993. Lipid metabolism in the rumen. J. Dairy Sci. 76: 3851-3863.

Johnson, R. R. 1976. Influence of carbohydrate solubility on nonprotein nitrogen utilization in the ruminant. J. Anim. Sci. 43:184-191.

Judkins, M.B., L.J. Krysl, R.K. Barton, D.W. Holcombe, S.A. Gunter, and J.T. Broesder. 1991. Effects of cottonseed meal supplementation time on ruminal fermentation and forage intake by Holstein steers fed fescue hay J. Anim. Sci. 69:3789-3797. 
Kamireddy, N, P.B. Kenney, S. Jittinandana and S. D. Slider. 2008. Acidified sodium chlorite solution as an antimicrobial treatment for rainbow trout (Oncorhynchus mykiss) fillets. J Food Prot. May;71(5):973-8.

Karmini, A. R., F. N. Owens, and G. W. Horn. 1986. Simultaneous extractions of Yb, Dy, and Co from feces with EDTA, DCTA or DTPA. J. Anim. Sci. 63(Suppl. 1):447. (Abstr.).

Kim, S., A.T. Adesogan, L. Badinga, and C.R. 2007. Staples. Effect of dietary n-6:n-3 fatty acid ratio on feed intake, digestibility, and fatty acid profiles of the ruminal contents, of liver and muscle of growing lambs. J. Anim. Sci. 85:706-716.

Krys1, L.J. and Hess, B.W. 1993. Influence of supplementation on behavior of grazing cattle. J. Anim. Sci. 71:2546-2555.

Krysl L. J., M. B. Judkins and V. R. Bohman. 1991. Influence of ruminal or duodenal soybean oil infusion on intake, ruminal fermentation, site and extent of digestion, and microbial protein synthesis in beef heifers consuming grass hay. J. Anim. Sci.69 2585-2590.

Kucuk, O., B.W. Hess, P.A. Ludden, and D.C. Rule. 2001. Effect of forage: concentrate ratio on ruminal digestion and duodenal flow of fatty acids in ewes. J. Anim. Sci. 79:2233-2240. 
Kucuk, O., B.W. Hess, and D.C. Rule. 2004. Soybean oil supplementation of high-concentrate diet does not affect site and extent of organic matter, starch, neutral detergent fiber, or nitrogen digestion, but influences both ruminal metabolism and intestinal flow of fatty acids in limit fed lambs J. Anim. Sci. 82:2985-2994.

Kucuk, O., B.W. Hess, D.C. Rule. 2007. Fatty acid compositions of mixed ruminal microbes isolated from sheep supplemented with soybean oil. Res. Vet. Sci. doi:10.1016/j.rvsc.2007.0410.

Lee, J.H., J.C. Waller, S.L. Melton, A.M. Saxton, and L.O. Pordesimo 2004. Feeding encapsulated ground full-fat soybeans to increase polyunsaturated fat concentrations and effects on flavor volatiles in fresh lamb. J. Anim. Sci. 82:2734-2741.

Leedle, J.A. Z., Bryant M.P., and Hespell R. B. 1982. Diurnal variations in bacterial numbers and fluid parameters in ruminal contents of animals fed low or high forage diets. Appl. and Envi Micr. Vol 44:(2) 402-412.

Litherland, N.B., Thire S., Beaulieu A.D., Reynolds C.K., Benson J.A., and Drackley J.K. 2005. Dry matter intake is decreased more by abomasal infusion of unsaturated free fatty acids than by unsaturated triglycerides. J. Dairy Sci. 88: 632-643.

Loor, J.J., Ueda K., Ferlay A., Chilliard Y., and Doreau M. 2004. Short communication: Diurnal profiles of conjugated linoleic acids and trans fatty acids in ruminal fluid from cows fed a high 
concentrate diet supplemented with fish oil, linseed oil or sunflower oil. J. Dairy Sci. 87: 24682471.

Loor, J.J., Ueda K., Ferlay A., Chilliard Y., and Doreau M. 2004. Biohydrogenation, duodenal flow, and intestinal digestibility of trans fatty acids and conjugated linoleic acids in response to dietary forage : concentrate ratio and linseed oil in dairy cows J. Dairy Sci. 87: 2472-2485.

Lough, D.S., M.B. Solomon, T.S. Rumsey, T.H. Elsasser, L.L. Slyter, S. Kahl, and G.P. Lynch. 1992. Effects of dietary canola seed and soy lecithin in high forage diets on cholesterol content and fatty acid composition of carcass tissues of growing ram lambs. J. Anim. Sci. 70:1153-1158.

Maeng, W.J., and R.L. Baldwin, 1976. Factors influencing rumen microbial growth rates and yields: Effects of amino acid addition to a purified diet with N from urea. J. Dairy Sci. 58:648655.

McCracken, B.A., M.B. Judkins, L.J. Krysl, D.W. Holcombe, and K.K. Park. 1993. Supplemental methionine and time of supplementation effects on ruminal fermentation digesta kinetics, and in situ dry matter and neutral detergent fiber disappearance in cattle. J. Anim. Sci. 71:1932-1939.

Meng, Q., M.S. Kerley, P.A. Ludden, and R.L. Belyea. 1999. Fermentation substrate and dilution rate interact to affect microbial growth and efficiency. J. Anim. Sci. 77:206-214. 
Mizwicki, K.L., F.N. Owens, K. Poling, and G. Burnett. 1980. Timed ammonia release for steers. J. Anim. Sci. 51:698-704.

N.R.C., 1985. Pages 46-47 in Nutrient Requirements of Sheep. 6th rev. ed. Natl. Acad. Press, Washington, DC.

Oldick , B.S., J.L. Firkins. 2000. Effects of degree of fat saturation on fiber digestion and microbial protein synthesis when diets are fed twelve times daily. J. Anim. Sci. 78:2412-2420.

Orr, R.J., P.D. Penning, A. Harvey, and R.A. Chapman. 1997. Diurnal patterns of intake by sheep grazing monocultures of ryegrass or white clover. Appl. Anim. Behav. Sci. 52:65-77.

Owens, F.N. and R.A. Zinn. 1988. Protein metabolism of ruminants. Pages 227- 249 in The ruminant animal, Digestive Physiology and Nutrition. D.C. Church ed. Prentice-Hall, Englewood Cliffs, NJ.

Palmquist, D. L. and T. C. Jenkins. 1980. Fat in lactation rations: review. J. Dairy Sci. 63:1-14.

Palmquist, D. L. 1991. Influence of source and amount of dietary fat on digestibility in lactating cows. J. Dairy Sci. 74:2601-2609.

Palmquist, D. L. 1994. The role of dietary fats in efficiency of ruminants. J. Nutr. 124:1377S1382S. 
Perez Alba, L.M., S. Cavalcanti, M. Hernandez, A. Marin, and G. Marin. 1997. Calcium soaps of olive fatty acids in the diet of Manchega dairy ewes: Effects on digestibility and production. J. Dairy Sci. 80: 3316-3324.

Ponnampalam EN, Sinclair AJ, Egan AR, Blakeley SJ, Leury BJ. 2001a. Effect of diets containing n-3 fatty acids on muscle long-chain n-3 fatty acid content in lambs fed low- and medium-quality roughage diets. J Anim Sci.;79 (3):698-706.

Ponnampalam EN, Sinclair AJ, Egan AR, Blakeley SJ, Li D, Leury BJ. 2001b. Effect of dietary modification of muscle long-chain n-3 fatty acid on plasma insulin and lipid metabolites, carcass traits, and fat deposition in lambs. J Anim Sci.;79 (4):895-903.

Ponnampalam EN, Sinclair AJ, Hosking BJ, Egan AR 2002. Effects of dietary lipid type on muscle fatty acid composition, carcass leanness, and meat toughness in lambs. J Anim Sci.;80 (3):628-636.

Qiu, X., M. L. Eastridge, K.E. Griswold, and J.L. Firkins. 2004. Effects of substrate passage rate, and $\mathrm{pH}$ in continuous culture on flows of conjugated linoleic acid and trans C18:1. J. Dairy Sci. $87: 3473-3479$.

Rayburn, E.B., and S.B. Rayburn. 1998. A standardized plate meter for estimating pasture mass in on-farm research trials. Agron. J. 90:238-241. 
Relling A. E., and C. K. Reynolds. 2007. Feeding Rumen-Inert fats differing in their degree of saturations decreases intake and increases plasma concentrations of gut peptides in lactating dairy cows. J. Dairy Sci. 90: 1506-1515.

Robinson, P. H., M. Gill, and J. J. Kennelly. 1997. Influence of time of feeding a protein meal on ruminal fermentation and forestomach digestion in dairy cows. J. Dairy Sci. 80:1366-1373.

Rook, A.J., C.A. Huckle, and P.D. Penning. 1994. Effects of sward height and concentrate supplementation on ingestive behavior of spring calving dairy cows grazing grass-clover swards. Appl. Anim. Behav. Sci. 40:101-112.

Rule, D. C., and D. C. Beitz. 1986. Fatty acids of adipose tissue, plasma, muscle and duodenal ingesta of steers fed extruded soybeans. J. Am. Oil Chem. Soc. 63:1429-1436.

SAS 2003. SAS/STAT Users guide. SAS Inst. Inc. Cary, NC.

Scollan, N.D., M. S. Dhanoa, N.J. Choi, W.J. Maeng, M. Enser, and J.D. Wood. 2001. Biohydrogenation and digestion of long chain fatty acids in steers fed on different sources of lipid. J. Agric. Sci. 136:345-355. 
Scollan, N.D., M. Enser, S.K. Gulati, I. Richardson, and J.D. Wood. 2003. Effects of including ruminally protected lipid supplement in the diet on the fatty acid composition of beef muscle. $\mathrm{Br}$. J. Nutr. 90:709-716.

Schauff, D. J., and J. H. Clark. 1989. Effects of prilled fatty acids and calcium salts of fatty acids on rumen fermentation, nutrient digestibilities, milk production and milk composition. J. Dairy Sci. 72: 917-927.

Solomon, M.B., G.P. Lynch, and D.S. Lough. 1992. Influence of dietary palm oil supplementation on serum lipid metabolites, carcass characteristics, and lipid composition of carcass tissues of growing ram and ewe lambs. J. Anim. Sci. 70:2746-2751.

Solomon MB, G.P Lynch, E. Paroczayn, 1991. Norton S. Influence of rapeseed meal, whole rapeseed, and soybean m.eal on fatty acid composition and cholesterol content of muscle and adipose tissue from ram lambs. J Anim Sci. Oct;69 (10):4055-4061.

Supelco. 1975. GC separation of VFA. Tech. Bull. No. 749B. Rev. ed. Supelco Inc., Bellefonte, PA.

Sutton, J. D., R. Knight, A. B. McAllan, and R. H. Smith. 1983. Digestion and synthesis in the rumen of sheep given diets supplemented with free or protected oils. Br. J. Nutr. 49:419-432. 
Ueda K., Ferlay A., Chabrot J., Loor J.J., Chilliard Y., and Doreau M. 2003. Effect of linseed oil supplementation on ruminal digestion in dairy cows fed diets with different forage : concentrate ratios. J. Dairy Sci. 86: 3999-4007.

Uden, P., P. E. Colucci, and P. J. Van Soest. 1980. Investigation of chromium, cerium and cobalt as markers in digesta rate of passage studies: Domestics animals fed timothy hay. J. Sci. Food Agric. 31:625-632.

Van Soest, P. J., J.B. Robertson, and B.A. Lewis. 1991. Methods for dietary fiber, neutral detergent fiber, and non starch polysacharides in relation to animal nutrition. J. Dairy Sci. 74 : $3538-3597$.

Van Soest, P. J. 1994. Nutritional Ecology of the Ruminant. Cornell Univ. Press, Ithaca, NY pg $152-178$.

Van Vuuren, A.M., C.J. Van der Koelen, and J. Vroons-de Bruin. 1986. Influence of the level and composition of concentrate supplements on rumen fermentation patterns of grazing dairy cows. Neth. J. Agric. Sci. 34:457-467.

Varga, G. A., and E. C. Prigge. 1982. Influence of forage species and levels of intake on ruminal turnover rates. J. Anim. Sci. 55:1498-1502. 
Wachira, A.M., L.A. Sinclair, R.G. Wilkinson, K. Hallet, M. Enser, and J.D. Wood. 2000. Rumen biohydrogenation of n-3 polyunsaturated fatty acids and their effects on microbial efficiency and nutrient digestibility in sheep. J. Agric. Sci. 135: 419-428.

Wachira AM, Sinclair LA, Wilkinson RG, Enser M, Wood JD, Fisher AV. 2002. Effects of dietary fat source and breed on the carcass composition, n-3 polyunsaturated fatty acid and conjugated linoleic acid content of sheep meat and adipose tissue.Br J Nutr. Dec;88 (6):697-709.

Wales, J.W., and P.T. Doyle. 2003. The effect of grain and straw supplementation on marginal milk production responses and ruminal fermentation of cows grazing highly digestible subterranean clover herbage. Aust. J. Exp. Agric. 43:467-474.

Wales, J.W., E.S. Kolver, P.L. Thorne, and A. Egan. 2004. Diurnal variation in ruminal pH on the digestibility of highly digestible perennial ryegrass during continuous culture fermentation. J. Dairy Sci. 87:1864-1871.

Weller, R.A. and A.F. Pilgrim. 1974. Passage of protozoa and volatile fatty acids from the rumen of a sheep and from a continuous invitro fermentation system. Brit. J. Nutr. 32:341-351.

West Virginia Sheep Management Project (WVSMP). Project Report 1998-1999. pg 1-12. 
Wiley, J.S., M.K. Petersen, C.K. Clark, R.P. Ansotegui, and D.W. Lodman. 1991. The influence of timing and addition of urea to supplements containing DL-methionine on ruminal fermentation and cow weight change in beef cows. J. Anim. Sci. 69:4617-4627.

Wynn R.J. Daniel Z.C.T.R., Flux C.L., Craigon J., Salter A.M. and Buttery P.J. 2006. Effect of feeding rumen-protected conjugated linoleic acid on carcass characteristics and fatty acid composition of sheep tissues. J. Anim. Sci. 84:3440-3450.

Wood, J. D., M. Enser, A.V. Fisher, G.R. Nute, R.I. Richardson, and P.R. Sheard. 1999.Manipulating meat quality and composition. Proc. Nutr. Soc. 58(2): 363-370.

Yokoyama M. T. and K. A. Johnson. 1988. Microbiology of the Rumen and Intestine. In: The Ruminant Animal: Digestive Physiology and Nutrition. D. C. Church, Ed pg 125-145. 
CURRICULUM VITAE

Quinn Stephan Baptiste
Parents

Birthplace

Date of Birth
Austin A. Baptiste Joyce A. Baptiste

San Fernando, Trinidad

December 28, 1969

Education:

Hardbargain Government Primary School

1974-1981

Hardbargain, Trinidad

Naparima Boy's College

1981-1989

San Fernando, Trinidad

University of the West Indies

1989-1993

St. Augustine, Trinidad

Agriculture Teacher Education Centre

1997-1999

Mausica, Trinidad

West Virginia University

2000-2002

Morgantown West Virginia

Degrees Received:

Master of Science in Reproductive Physiology

2002

West Virginia University

2000-2002

Morgantown West Virginia

Bachelor of Science in Agriculture

1993

University of the West Indies

St. Augustine, Trinidad

Diploma in Agricultural Education

1999

Agriculture Teacher Education Centre

Mausica, Trinidad

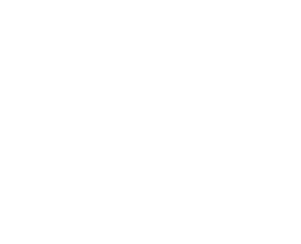

